Aus der Klinik für Kardiologie und Pneumologie

(Leiter: Prof. Dr. med. G. Hasenfuß)

der Medizinischen Fakultät der Universität Göttingen

\title{
In-vitro-Charakterisierung und kardiale Differenzierung von induziert pluripotenten Stammzellen der Maus
}

\author{
INAUGURAL - DISSERTATION \\ zur Erlangung des Doktorgrades \\ der Medizinischen Fakultät der \\ Georg-August-Universität zu Göttingen
}

vorgelegt von

Max-Philipp Lentzen

aus Berlin

Göttingen 2015 
Dekan:

Prof. Dr. rer. nat. H. K. Kroemer

I. Berichterstatter/in: Prof. Dr. rer. nat. K. Guan-Schmidt

II. Berichterstatter/in: Prof. Dr. med. R. Dressel

III. Berichterstatter/in: Prof. Dr. hum. biol. M. Schön

Tag der mündlichen Prüfung: $\quad$ 06.04.2016 


\section{Inhaltsverzeichnis}

$\begin{array}{ll}\text { Abkürzungsverzeichnis } & 6\end{array}$

Einheitenverzeichnis 9

Abbildungsverzeichnis 10

Tabellenverzeichnis 11

$1 \quad$ Einleitung 12

1.1 Herzinsuffizienz und Therapiemöglichkeiten 12

1.2 Stammzellen als Therapiemöglichkeit der Herzinsuffizienz 16

1.2.1 Embryonale Stammzellen (ES) 16

$\begin{array}{lll}1.2 .2 \text { Adulte Stammzellen } & 18\end{array}$

1.2.3 Induziert pluripotente Stammzellen (iPS) 19

1.2.4 Zellbasierte Therapie der Herzregeneration

- Stand der Technik 22

$\begin{array}{lll}1.3 & \text { Zielsetzung } & 25\end{array}$

$2 \quad$ Material und Methoden 27

$\begin{array}{lll}2.1 & \text { Zelllinien } & 27\end{array}$

2.2 Medien, Lösungen und Substanzen 28

2.3 Oligonukleotide 31

2.4 Antikörper 32

2.5 Versuchstiere: Mhc-Neo/Mhc-eGfp-Mäuse 33

2.6 Gewinnung und Kultivierung von mES und miPS 33

2.6.1 Gewinnung von mouse embryonic fibroblasts (MEFs) 34

2.6.2 Gewinnung von mES 34

2.6.3 Gewinnung von miPS $\quad 35$

2.6.4 Kokultivierung der undifferenzierten murinen ES und iPS mit MEFs 36

2.7 In-vitro-Differenzierung von mES und miPS 37

2.7.1 Selektion der Kardiomyozyten 38

2.8 Analyse der expandierenden undifferenzierten pluripotenten Zellen $\quad 39$

$\begin{array}{lll}2.8 .1 \text { Zellzählung } & 39\end{array}$ 
2.8.2 Karyotypisierung 40

2.8.3 Alkalische Phosphatase-Färbung 41

2.9 Isolation von DNA und Methylierungs-Analyse 41

2.10 mRNA-Expressions-Analysen der undifferenzierten, ungerichtet differenzierten Zellen und Kardiomyozyten $\quad 42$

2.10.1 Isolation von RNA $\quad 42$

2.10.2 Reverse Transkription 43

2.10.3 Polymerasekettenreaktion (PCR) 44

2.10.4 Gelelektrophorese 45

2.11 Immunfluoreszenz-Analyse der undifferenzierten Zellen und Kardiomyozyten $\quad 45$

2.12 Quantitative Analyse der Kardiomyozyten 46

2.13 Statistische Analysen 46

3 Ergebnisse $\quad 47$

3.1 Nachweis der Pluripotenz 47

3.2 Analyse der Zellproliferation 54

3.3 Karyotypisierung der analysierten miPS-Linien

3.4 Kardiale Differenzierung der miPS-Linien und mES-Linie 57

3.4.1 Gen- und Proteinexpression kardialer Marker 57

3.4.2 Quantitative Analyse des Kardiomyozytenanteils der In-vitro-Differenzierung $\quad 61$

4 Diskussion 64

4.1 Reprogrammierung somatischer Zellen in iPS 64

4.2 Nachweis der Pluripotenz 65

4.2.1 Expression der Pluripotenzmarker 66

4.2.2 DNA-Methylierung 68

4.2.3 In-vitro-Differenzierungspotenzial 69

4.3 Analyse der Zellproliferation 70

4.4 Karyotypisierung der kultivierten miPS und mES 71

4.5 Kardiale Differenzierung muriner iPS und ES $\begin{array}{ll}\text { und deren Charakterisierung } & 73\end{array}$

4.6 Aufreinigung der aus murinen iPS und ES differenzierten Kardiomyozyten $\quad 75$ 
$\begin{array}{lll}4.7 & \text { Schlussfolgerung und Ausblick } & 78\end{array}$

5 Zusammenfassung 79

Literaturverzeichnis $\quad 81$

$\begin{array}{ll}\text { Danksagung } & 95\end{array}$ 


\section{Abkürzungsverzeichnis}

Abb.

ACE

Afp

AL-Puffer

Anf

a-Mhc

BSA

$\beta-M E$

$\beta-M h c$

ca.

cDNA

c-Kit

c-Myc

COPD

Cy3

DAPI

DBA

DEPC

dest.

DMEM

DMSO

DNA

DNase

dNTPs

DPBS

EB

EDTA

eGfp

ES

et al.

$\mathrm{EtOH}$
Abbildung

angiotensin converting enzyme

a-Fetoprotein

Aluminium-Puffer

atrialer natriuretischer Faktor

a-myosin heavy chain

Rinderserumalbumin (bovine serum albumin)

$\beta$-Mercaptoethanol

$\beta$-myosin heavy chain

circa

komplementäre DNA (complementary DNA)

tyrosine-protein kinase Kit (CD 117)

v-myc myelocytomatosis viral oncogene homolog (avian)

chronic obstructive pulmonary disease

Indocarbocyanin

4,6- diamino-2-phenylindol

dilute brown non-agouti

Diethylpyrocarbonat

destilliert

Dulbecco's modified Eagle's medium

Dimethylsulfoxid

Desoxyribonukleinsäure (deoxyribonucleic acid)

Desoxyribonuklease

Desoxynukleosidtriphosphate

Dulbeccos Phosphat-gepufferte Salzlösung

embryoid body

Ethylendiamintetraessigsäure

enhanced green fluorescence protein

embryonale Stammzellen

und andere (et alii)

Ethanol 


\begin{tabular}{|c|c|}
\hline$f$ & vorwärts (forward) \\
\hline $\mathrm{F}$ & Fragmentlänge \\
\hline FACS & $\begin{array}{l}\text { Fluoreszenz-aktivierte Zellsortierung (fluorescence activated cell } \\
\text { sorting) }\end{array}$ \\
\hline FBB & fibrous bed bioreactor \\
\hline FBS & fetales Kälberserum (fetal bovine serum) \\
\hline FISH & fluorescence in situ hybridization \\
\hline FITC & Fluorescein-5-isothiocyanat \\
\hline $\mathrm{FL}$ & feeder layer \\
\hline Flk1 & fetale Leberkinase 1 \\
\hline FLOW & Durchflusszytometrie (Fluss-Sortierer) \\
\hline G418 & Geneticin \\
\hline Gapdh & Glycerinaldehyd-3-Phosphat-Dehydrogenase \\
\hline $\mathrm{h}$ & human \\
\hline \multirow[t]{2}{*}{ hbFGF } & humaner Hauptfibroblastenwachstumsfaktor (human basic \\
\hline & fibroblast growth factor) \\
\hline HD & hanging drop \\
\hline hES & humane embryonale Stammzellen \\
\hline hiPS & humane induzierte pluripotente Stammzellen \\
\hline ICD & implantable cardioverter defibrillator \\
\hline $\mathrm{ICM}$ & inner cell mass \\
\hline $\lg G$ & Immunglobulin G \\
\hline $\lg M$ & Immunglobulin M \\
\hline IMDM & Iscove's modified Dulbecco's medium \\
\hline iPS & induziert pluripotente Stammzellen \\
\hline IRES & internal ribosomal entry site \\
\hline$|s| 1$ & Insulin gene enhancer protein \\
\hline $\mathrm{KCl}$ & Kaliumchlorid \\
\hline Klf4 & krueppel-like factor 4 \\
\hline KMSZ & Knochenmarkstammzellen \\
\hline LIF & Leukämiezellen inhibierender Faktor (leukemia inhibitory factor) \\
\hline Lin28 & cell lineage abnormal 28 \\
\hline In & Logarithmus naturalis \\
\hline $\mathrm{m}$ & murin \\
\hline
\end{tabular}




\begin{tabular}{|c|c|}
\hline Mash1 & Achaete-scute complex like 1 \\
\hline MEFs & murine embryonale Fibroblasten (mouse embryonic fibroblasts) \\
\hline MEF-2 & myocyte enhancer factor-2 \\
\hline mES & murine embryonale Stammzellen \\
\hline $\mathrm{MHC}$ & myosin heavy chain \\
\hline miPS & murine induzierte pluripotente Stammzellen \\
\hline miRNA & mikro-RNA \\
\hline Mlc2v & myosin regulatory light chain 2 , ventricular isoform \\
\hline MMC & Mitomycin C \\
\hline $\mathrm{MnCl}_{2}$ & Mangan-di-chlorid \\
\hline $\mathrm{MOI}$ & Multiplizität der Infektion (multiplicity of infection) \\
\hline mRNA & Boten-RNA (messenger RNA) \\
\hline MTG & a-Monothioglycerol \\
\hline M-FISH & multiplex fluorescence in situ hybridization \\
\hline $\mathrm{n}$ & Anzahl (number) \\
\hline NEAA & nicht-essentielle Aminosäuren (non-essential amino acids) \\
\hline Neo & Neomycin-/Geneticinresistenzgen \\
\hline Nkx2.5 & NK2 homebox 5 \\
\hline Oct4 & Octamer binding transcription factor 4 \\
\hline $\mathrm{p}$ & Passage \\
\hline PFA & Paraformaldehyd \\
\hline PCR & Polymerasekettenreaktion (polymerase chain reaktion) \\
\hline r & rückwärts (reverse) \\
\hline RNA & Ribonukleinsäure (ribonucleic acid) \\
\hline RNase & Ribonuklease \\
\hline RT & Raumtemperatur \\
\hline RT-PCR & reverse Transkriptions-Polymerasekettenreaktion \\
\hline Sca1 & stem cell antigen-1 \\
\hline SD & Standardabweichung (standard deviation) \\
\hline SKY & spectral karyotyping \\
\hline Sox2 & sex determining region $Y(S R Y)-b o x 2$ \\
\hline SSEA-1 & stage-specific embryonic antigen 1 \\
\hline STEMCCA & stem cell cassette \\
\hline $\mathrm{T}_{\mathrm{A}}$ & Annealingtemperatur \\
\hline
\end{tabular}


Tab.

Tabelle

Taq thermus aquaticus

TB-Puffer Tris-Borsäure-Puffer

T/E Trypsin/EDTA

Tris Tris(hydroxymethyl)-aminomethan

u.a. unter anderem Zyklenanzahl

Zentrale Tierexperimentelle Einrichtung der Universitätsmedizin Göttingen

\section{Einheitenverzeichnis}

$\begin{array}{ll}\mathrm{bp} & \text { Basenpaare } \\ \mathrm{cm} & \text { Zentimeter } \\ \mathrm{d} & \text { Tag (day) } \\ \mathrm{g} & \text { Gramm } \\ \mathrm{g} & \text { Erdbeschleunigung } \\ \mathrm{kb} & \text { Kilobasen } \\ \mathrm{mg} & \text { Milligramm } \\ \mathrm{min} & \text { Minuten } \\ \mathrm{ml} & \text { Milliliter } \\ \mathrm{mm} & \text { Millimeter } \\ \mathrm{mM} & \text { Millimol } \\ \mathrm{ng} & \text { Nanogramm } \\ \mathrm{S} & \text { Sekunden } \\ \mathrm{std} & \text { Stunden } \\ \mathrm{U} & \text { unit } \\ \mathrm{V} & \text { Volt } \\ \mu \mathrm{g} & \text { Mikrogramm } \\ \mu \mathrm{l} & \text { Mikroliter } \\ \mu \mathrm{m} & \text { Mikrometer } \\ \mu \mathrm{M} & \text { Mikromolar } \\ { }^{\circ} \mathrm{C} & \text { Grad Celsius }\end{array}$




\section{Abbildungsverzeichnis}

Abb. 1: Circulus vitiosus der Herzinsuffizienz 13

Abb. 2: Differenzierungspotenzial von Stammzellen 17

Abb. 3: Gewinnung und Kultivierung verschiedener Stammzellen 20

Abb. 4: Für die kardiale Therapie zur Verfügung stehende Zelltypen und Mechanismen 24

Abb. 5: Das humanisierte lentivirale STEMCCA-System 35

Abb. 6: Protokoll der kardialen Differenzierung und Selektion 39

Abb. 7: Morphologie und alkalische Phosphataseaktivität 48

Abb. 8: Genexpressionsanalyse der Zellinien IMOI1, VMOI1 und ES-7 (jeweils $n=3$ ) 49

Abb. 9: Immunfluoreszenzfärbungen der Zelllinien IMOI1, VMOI1

$\begin{array}{ll}\text { und ES-7 } & 50\end{array}$

Abb. 10: Darstellung der Methylierungsgrade der iPS IMOI1 und VMOI1 verglichen mit ihren jeweiligen MEFs

Abb. 11: Morphologie der IMOI1, VMOI1 und ES-7 Zellen während der Differenzierung 52

Abb. 12: Genexpressionsanalyse zur Differenzierung der Zelllinien IMOI1, VMOI1 und ES-7 53

Abb. 13: Zellproliferationsanalyse der Zellen IMOI1, VMOI1 und ES-7 55

Abb. 14: Analyse des Karyotyps der Zelllinien IMOI1, VMOI1 und ES-7 56

Abb. 15: Genexpressionsanalyse kardialer Marker in den Zellen IMOI1, VMOI1 und ES-7

Abb. 16: Immunfluoreszenzfärbung des kardialen Markers a-Aktinin in den Zelllinien IMOI1(a), VMOI1(b) und ES-7(c)

Abb. 17: Darstellung der durchflusszytometrischen Ergebnisse anhand des Beispiels ES-7 zum Zeitpunkt Tag 15

Abb. 18: Quantitative Bestimmung des Kardiomyozytenanteils in Differenzierungskulturen der Zellen IMOI1, VMOI1 und ES-7 


\section{Tabellenverzeichnis}

Tab. 1: Oligonukleotide 31

Tab. 2: Primärantikörper 32

Tab. 3: Sekundärantikörper 33

Tab. 4: Komponenten einer $20 \mu \mathrm{l}$ RT-PCR-Reaktion 43

Tab. 5: Programm für cDNA-Synthese $\quad 43$

Tab. 6: Komponenten eines PCR Master Mix $(48 \mu \mathrm{l})$

Tab. 7: Programm für PCR 44

Tab. 8: Karyotypisierung der Zellen IMOI1, VMOI1 und ES-7 57 


\section{Einleitung}

\subsection{Herzinsuffizienz und Therapiemöglichkeiten}

Die Herzinsuffizienz ist eine sehr häufige und weit verbreitete Erkrankung. Zwischen $1 \%$ und $2 \%$ der erwachsenen Bevölkerung leiden an einer Herzinsuffizienz. In erster Linie betrifft die Erkrankung jedoch ältere Leute. Bei den über 65-Jährigen leiden bereits $6 \%$ bis $10 \%$ an der Erkrankung (McMurray \& Pfeffer 2005). Keine andere chronische Erkrankung reduziert die Lebensqualität so sehr wie die Herzinsuffizienz (Hobbs 2002). Auch geht die Erkrankung mit einer hohen Sterblichkeit einher. 30\% bis $40 \%$ der Patienten versterben noch im Jahr der Diagnosestellung, $60 \%$ bis $70 \%$ in den folgenden fünf Jahren (Bleumink et al. 2004).

Die Pathophysiologie der Herzinsuffizienz entsteht als Folge einer abnormen kardialen Struktur und/oder Funktion. Sie kann jedoch auch durch einen pathologischen Rhythmus oder abnorme elektrische Reizweiterleitung entstehen. In den Industrieländern ist eine ventrikuläre Fehlfunktion die häufigste Ursache. Generell gelten als Hauptursachen der Myokardinfarkt und der arterielle Hypertonus. Während der Myokardinfarkt zu einer systolischen Dysfunktion führt, bedingt der Hypertonus sowohl eine systolische wie auch eine diastolische Fehlfunktion. In vielen Fällen bestehen jedoch beide Ätiologien. Weitere Ursachen der Herzinsuffizienz sind degenerative Klappenerkrankungen, die idiopathische dilatative Kardiomyopathie, genetische Herzerkrankungen und die Alkohol-bedingte Kardiomyopathie (McMurray \& Pfeffer 2005).

Die systemischen Prozesse, die mit einer Herzinsuffizienz einhergehen, betreffen neben dem Herzen zahlreiche andere Organsysteme. Hierzu zählen beispielsweise die Lunge, Blutgefäße, Nieren, Muskulatur und die Leber, welche in den Circulus vitiosus der Herzinsuffizienz mit einbezogen werden (Francis 2001) (Abb. 1). 


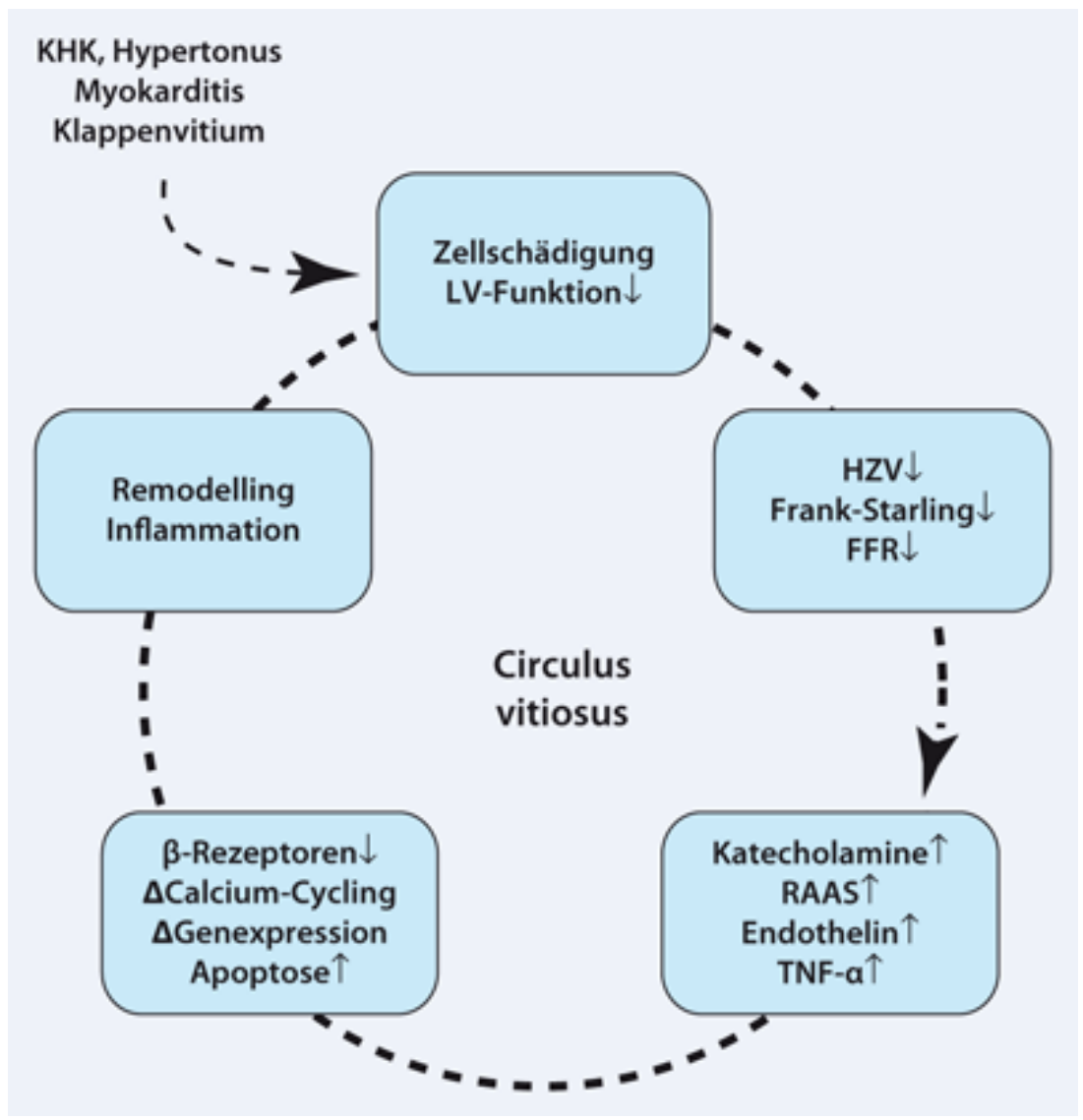

\section{Abb. 1: Circulus vitiosus der Herzinsuffizienz.}

Die Pathophysiologie der Herzinsuffizienz wird beeinflusst von physiologischen Prozessen, endokrinen Systemen, Elektrolyt- und strukturellen Gewebeveränderungen. Diese einzelnen Komponenten können die Pathophysiologie kontinuierlich fortführen und mit fortschreitender Erkrankung sogar verstärken (http://link.springer.com/static-content/images/752/art\%253A10.1007\% 252Fs12181-011-0325-3/MediaObjects/12181_2011_325_Fig1_HTML.gif). LV: Linker Ventrikel, HZV: Herzzeitvolumen, FFR: fractional flow reserve, RAAS: Renin-Angiotensin-Aldosteron-System, TNF- $\alpha$ : Tumornekrosefaktor $\alpha$.

Die molekularen, strukturellen und funktionellen Veränderungen im Herzen und die systemischen Prozesse, einhergehend mit Elektrolytverschiebungen, führen letztendlich zur elektrischen und mechanischen Dysfunktion (Daubert et al. 2004; Bleasdale \& Frenneaux 2004). Des Weiteren gelten die Vorhoffunktion, eine synchrone Kontraktion des linken Ventrikels und eine physiologische Interaktion zwischen linkem und rechtem Ventrikel als entscheidend für ein adäquates Schlagvolumen (Daubert et al. 2004; Bleasdale \& Frenneaux 2004).

Eine entscheidende Rolle bei der Herzinsuffizienz spielen die Begleiterkrankungen. Diese können durch die kardialen Probleme an sich oder die Ätiologie der Herzinsuffizienz (z.B. Hypertonus) bedingt sein. Außerdem kann das Alter der 
Patienten, aber auch beispielsweise die medikamentöse Therapie der Herzinsuffizienz zu einer Komorbidität führen (Braunstein et al. 2003). Begleiterkrankungen, der ursächliche pathophysiologische Prozess, die Aktivität der systemischen Signalkaskaden und das Alter des Patienten sind die wichtigsten Determinanten der Prognose (McMurray \& Pfeffer 2005).

Die Herzinsuffizienz kann sich in dreierlei Hinsicht manifestieren. Akut, beispielsweise als Konsequenz eines stattgehabten Myokardinfarkts, als chronische Erkrankung oder akut auf chronisch. Die akut auf chronische Form der Erkrankung tritt meist auf, wenn eine Verschlechterung der Symptome zu einer Dekompensation führt. Die meisten Kardinalsymptome der Herzinsuffizienz wie Dyspnoe, Leistungsschwäche und periphere Ödeme sind vor allem bei älteren Patienten wenig spezifisch. Sie können ebenso durch Erkrankungen wie chronic obstructive pulmonary disorder (COPD), Anämie, venöse Insuffizienz, renale Dysfunktion, Hypothyreose oder eine medikamentöse Therapie bedingt sein. Spezifischere Symptome wie eine Halsvenenstauung, Kardiomegalie oder ein dritter Herzton sind deutlich seltener und schwieriger zu detektieren (Davie et al. 1997; Khunti et al. 2000). Als technisches Hilfsmittel steht vor allem die Echokardiographie bei der Diagnosestellung im Vordergrund. Außerdem finden die Elektrokardiographie, die Röntgen-Thorax Aufnahme und die klinische Chemie ihre Anwendung in der Diagnostik (McMurray \& Pfeffer 2005). Auch die Magnetresonanztomographie gewinnt zunehmend an Bedeutung bei den bildgebenden diagnostischen Verfahren der Herzinsuffizienz (Nikitin et al. 2004).

Die Ziele der Herzinsuffizienztherapie sind in erster Linie eine gezielte Behandlung der Symptome, Klinikaufenthalte zu minimieren bzw. zu verhindern und das Überleben zu verlängern. Hierbei ist die medikamentöse Therapie die wichtigste Säule zur Behandlung der Herzinsuffizienz und einer reduzierten linksventrikulären Ejektionsfraktion (McMurray \& Pfeffer 2005). Bei Patienten mit einer reduzierten, linksventrikulären, systolischen Funktion ist die Gabe von Diuretika essentiell, um die Symptomatik der Dyspnoe sowie der Natrium- und Wasserretention behandeln zu können (Faris et al. 2002). Bei Patienten mit einer systolischen Dysfunktion kommen vor allem angiotensin converting enzyme Inhibitoren (ACE-Hemmer) zur Anwendung. Diese verbessern die Symptomatik, führen zu weniger Klinikaufenthalten und verlängern das Überleben (CONSENSUS Trial Study Group 1987; SOLVD Investigators 1991; Cohn et al. 1991). Des Weiteren helfen Betablocker, das 
insuffiziente Herz vor den potentiell schädigenden Effekten von Adrenalin und Noradrenalin zu schützen. Ihre Gabe zeigte eine substanzielle Reduktion von Mortalität und Morbidität und eine Verbesserung der Symptome (Hjalmarson \& Fagerberg 2000; Packer 2001; Packer et al. 2002; Flather et al. 2005). Bei schwerer symptomatischer Herzinsuffizienz finden neben den bereits genannten Medikamenten Aldosteron-Antagonisten wie Spironolacton ihre Anwendung. Diese konnten ebenfalls eine Reduktion der Mortalität und Morbidität wie auch eine Symptomverbesserung bewirken (Pitt et al. 1999). Bei Patienten mit einem begleitenden Vorhofflimmern, kann bei fehlendem Ansprechen auf Betablocker zur Frequenzkontrolle Digoxin gegeben werden (Digitalis Investigation Group 1997). Es zeigte sich jedoch auch, dass sich die Herzinsuffizienz nach Absetzen der Digitalis Therapie verschlechterte (Packer 1993).

Bei Patienten mit einer Herzinsuffizienz bei erhaltener linksventrikulärer, systolischer Funktion werden ebenfalls Diuretika empfohlen (McMurray et al. 2001). Auch Betablocker kommen zur Anwendung. Sie bewirken neben der Frequenzreduktion eine Steigerung der Relaxation und führen somit zu einer Erhöhung der diastolischen Füllung. Ihre anti-ischämischen und anti-hypertensiven Effekte zeigen sich zusätzlich vorteilhaft (Flather et al. 2005).

Neben der medikamentösen Therapie ist vor allem die Anwendung von Herzschrittmachern bzw. sogenannten assist devices und die chirurgische Therapie klinisch relevant. In der SCD HeFT-Studie konnte gezeigt werden, dass ein sog. implantable cardioverter defibrillator (ICD) das Risiko, am Herztod zu versterben, um 23\% reduzieren kann. Dies gilt für Patienten mit leichter bis schwerer Herzinsuffizienz und reduzierter linksventrikulärer Ejektionsfraktion, die eine optimale medizinische Behandlung erhielten (Bardy et al. 2005).

Orthotope oder heterotope Transplantion stellt die letzte Möglichkeit zur Behandlung von Patienten mit schwerer Herzinsuffizienz dar. Die mangelnde Verfügbarkeit von Spenderorganen schränkt diese Therapiemöglichkeit jedoch deutlich ein und bewirkt gleichzeitig ein steigendes Interesse an Xenotransplantationen (Trulock et al. 2004; Ogata \& Platt 2004). Ventrikuläre assist devices können hierbei zur Überbrückung des Zeitraums vor der Transplantation dienen; es gibt jedoch auch ein steigendes Interesse, diese als finale Therapie zu verwenden (Rose et al. 2001). 
Letztendlich ist das Ziel der Herzinsuffizienztherapie die Reparatur bzw. das Ersetzen von abgestorbenen und geschädigten Kardiomyozyten. Ob dies mittels Zell- oder Gentherapie möglich ist, muss die Forschung zeigen (Melo et al. 2004).

\subsection{Stammzellen als Therapiemöglichkeit der Herzinsuffizienz}

Zur Behandlung der Herzinsuffizienz wurden über die Jahre verschiedenste medikamentöse und operative Therapien entwickelt. Trotzdem ist die Erkrankung in den Industrieländern nach wie vor eine Hauptursache für eine hohe Morbidität und Mortalität (Yoshida \& Yamanaka 2011).

Die ursächliche Pathologie besteht darin, dass die Regenerationsmöglichkeit des menschlichen Myokards nicht ausreichend ist, um einen größeren Verlust von Herzmuskelgewebe zu kompensieren. Dieser tritt beispielsweise bei einem Myokardinfarkt, aber auch anderen myokardialen Erkrankungen auf (Segers \& Lee 2008). Aus diesem Grund wurde eine Vielzahl von Strategien entwickelt, bei denen man beispielsweise Kardiomyozyten oder kardiomyogene Stammzellen ins Herz transplantiert, um den Verlust an Herzmuskelgewebe zu ersetzen und die Knappheit von verfügbaren Spenderherzen zu umgehen (Yoshida \& Yamanaka 2011).

Stammzellen, Basis für eine Zellersatztherapie, sind definiert als undifferenzierte Zellen, welche die Fähigkeit besitzen, sich über einen gewissen Zeitraum selbst zu erneuern und in spezielle Zelltypen zu differenzieren. Man kann sie in natürlich vorkommende embryonale und postembryonale (fetale, neonatale, adulte) sowie durch Manipulation induzierte pluripotente Stammzellen unterteilen.

\subsubsection{Embryonale Stammzellen (ES)}

ES sind Zellen, die sich in jegliches Gewebe entwickeln können. Dazu differenzieren sich ES zuvor in Zellen der drei Keimblätter Entoderm, Ektoderm und Mesoderm sowie der Keimbahn aus. Daraus entstehen gewebespezifische Stammzellen wie hämatopoetische, neurale und mesenchymale/stromale. Auch in Kultur genommen entwickeln ES sich unter verschiedenen Kulturbedingungen zu unterschiedlichen Typen differenzierter Zellen wie zum Beispiel Leberzellen, Nervenzellen und Blutzellen. Deshalb bezeichnet man ES als pluripotent, d.h. sie tragen viele Entwicklungsmöglichkeiten in sich. 
ES können aus der inner cell mass (ICM) der Blastozyste (3-5 Tage alter Embryo) gewonnen werden (Abb. 2). Evans und Kaufmann entdeckten 1981 als erste diese Möglichkeit und schufen Kulturbedingungen, um Maus-ES in vitro im pluripotenten, undifferenzierten Zustand kultivieren zu können (Evans \& Kaufmann 1981; Martin 1981). 15 Jahre später gelang dieses mit nicht-humanen Primaten ES (Thomson et al. 1995, 1996). 1998 zeigten ebenfalls Thomson et al. erstmals die Isolierung von humanen ES (hES) aus der ICM der Blastozyste humaner Embryos. Auch nach fünfmonatiger In-vitro-Kultivierung zeigten die hES die Fähigkeit, sich in alle drei embryonalen Keimblätter differenzieren zu können (Thomson et al. 1998).

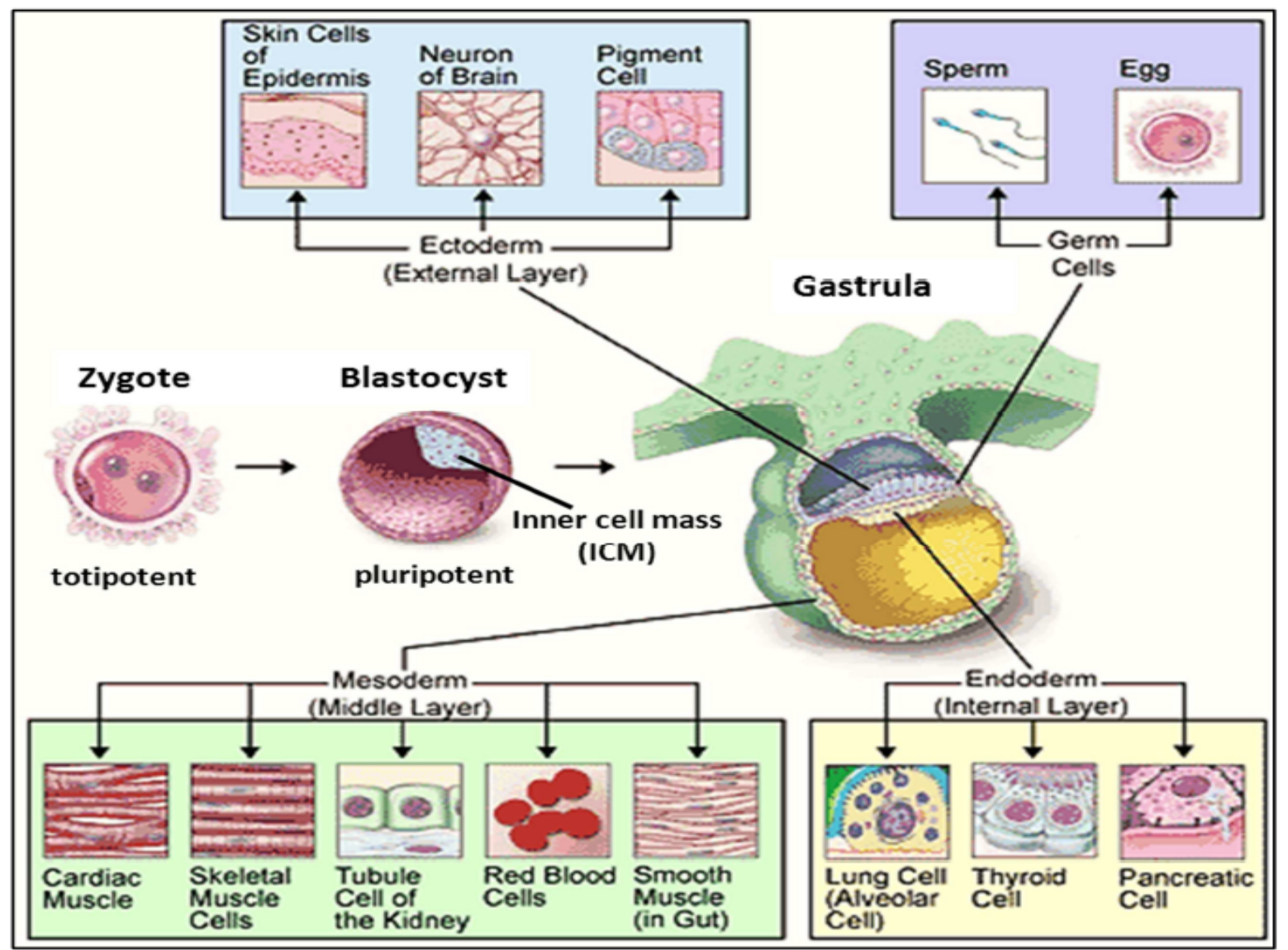

Abb. 2: Differenzierungspotenzial von Stammzellen.

Die befruchtete Eizelle (Zygote) ermöglicht die Entstehung eines kompletten Organismus. Im Stadium der Blastozyste kann aus der inner cell mass (ICM) jeder Zelltyp eines Organismus entstehen. Adulte Stammzellen können später in der Entwicklung in nahezu jedem Gewebe des Körpers gefunden werden (National Institutes of Health, U.S.A. (http://www.ncbi.nlm.nih.gov/About/primer/genetics_cell $. h t m l))$.

Um den pluripotenten, undifferenzierten Status der Zellen zu erhalten, ist es notwendig, die Zellen auf inaktivierten embryonalen Mausfibroblasten (MEF) in 
Anwesenheit von leukemia inhibitory factor (LIF) zu kultivieren (Burdon et al. 1999). Dies gilt in dieser Form für ES der Maus. Für hES wird anstelle von LIF human basic fibroblast growth factor (hbFGF) verwendet.

ES sind außerdem durch inre Klonalität, einen Mangel des G1-Checkpoints im Zellzyklus, eine hohe Telomerase-Aktivität sowie einen physiologischen, diploiden Karyotyp charakterisiert. Für den pluripotenten, undifferenzierten Zustand der Zellen ist vor allem die Expression gewisser Transkriptionsfaktoren verantwortlich. Zu diesen zählen in erster Linie octamer binding transcription factor 4 (Oct4), sex determing region of Y-box2 (Sox2) und Nanog (Nichols et al. 1998; Niwa et al. 2000; Avilion et al. 2003; Chambers et al. 2003; Mitsui et al. 2003).

1990 bzw. 1993 konnten Nagy et al. ein weiteres Charakteristikum von ES zeigen: Die Fähigkeit bei induzierter Differenzierung sich sowohl im In-vitro- als auch im Invivo-Experiment, z.B. nach Injektion der entsprechenden Blastozyste in eine Maus, abgeleitet von den Zellen aller drei Keimblätter (Endo-, Meso- und Ektoderm) zu differenzieren (Nagy et al. 1990, 1993).

Ein weiterer Beweis für die Pluripotenz der Zellen wurde durch die Injektion von undifferenzierten, pluripotenten Stammzellen in immundefiziente Mäuse mit der Folge einer Teratombildung erbracht (Smith 2001). Die Autoren konnten damit frühere Untersuchungen von Evans \& Kaufmann (1981) bestätigen, die gezeigt hatten, dass die Zellen nach Injektion in vivo Teratome bildeten und einen physiologischen Karyotyp aufwiesen.

\subsubsection{Adulte Stammzellen}

Adulte Stammzellen zeichnen sich durch zwei Charakteristika aus. Erstens können sie für einen gewissen Zeitraum Kopien ihrer selbst erstellen und sich somit selbst erneuern. Zweitens sind sie in der Lage, sich zu reifen Zellen zu entwickeln, die durch ihre spezielle Form und Funktion Gewebe des menschlichen Körpers bilden. Man bezeichnet sie als multipotent, da sie nur eine begrenzte Anzahl von Zelltypen hervorbringen können.

Somit zählen der Erhalt der Zellhomöostase und die Erneuerung von nicht-vitalem Gewebe, wobei diese limitiert ist, zu ihren Hauptaufgaben (Holtzer et al. 1978; Leblond 1964).

Ein Beispiel für adulte Stammzellen sind die Knochenmarkstammzellen (KMSZ). Diese werden lebenslang generiert und besitzen die Aufgabe, Zellen des Blutes zu 
bilden (Domen \& Weissman 1999). Sie werden bereits therapeutisch im Rahmen von Transplantationen eingesetzt (National Institutes of Health 2001).

Auch wenn der Ursprung im Gegensatz zu ES bis heute ungeklärt ist, weiß man, dass adulte Stammzellen beispielsweise neben dem Knochenmark in Retina, Gastrointestinaltrakt, Blutgefäßen, Skelettmuskulatur, zentralem Nervensystem sowie Hautepithelien vorkommen.

Inzwischen konnte in verschiedenen Laboratorien gezeigt werden, dass auch residente (adulte) kardiale Stammzellen das Potenzial zur Differenzierung in Kardiomyozyten und andere Zelltypen wie Endothelzellen und vaskuläre glatte Muskelzellen haben (Beltrami et al. 2003; Oh et al. 2003; Martin et al. 2004; Laugwitz et al. 2005).

\subsubsection{Induziert pluripotente Stammzellen (iPS)}

IPS sind pluripotente Stammzellen, die aus nicht-pluripotenten somatischen (adulten) Zellen gewonnen werden können. Dazu werden adulte somatische Zellen zu ESähnlichen Zellen durch die Aktivierung embryonaler Gene (Transkriptionsfaktoren) reprogrammiert. 1997 zeigten Wilmut et al. erstmals eine Reprogrammierung somatischer Zellen durch einen Transfer von Zellkernbestandteilen in Oozyten. Weitere Arbeitsgruppen konnten beweisen, dass eine Reprogrammierung auch über eine Fusion somatischer Zellen mit ES möglich ist (Tada et al. 2001; Cowan et al. 2005).

Takahashi und Yamanaka zeigten 2006 erstmals die Generierung sogenannter induziert pluripotenter Stammzellen der Maus (miPS). Hierzu wurden in Fibroblasten der Maus unter Verwendung von vier unabhängigen retroviralen Vektoren die vier reprogrammierenden Transkriptionsfaktoren oder Pluripotenz-assoziierten Marker Oct4, Sox2, c-Myc (myelocytomatosis viral oncogene homolog) und Krueppel-like factor 4 (KIf4) transduziert. Daraufhin konnten auch bald die ersten humanen induziert pluripotenten Stammzellen (hiPS) aus menschlichen Fibroblasten durch Reprogrammierung generiert werden (Takahashi et al. 2007; Yu et al. 2007) (Abb. 3). Allerdings scheinen diese schwieriger als murine Zellen reprogrammierbar zu sein (Park et al. 2008). 

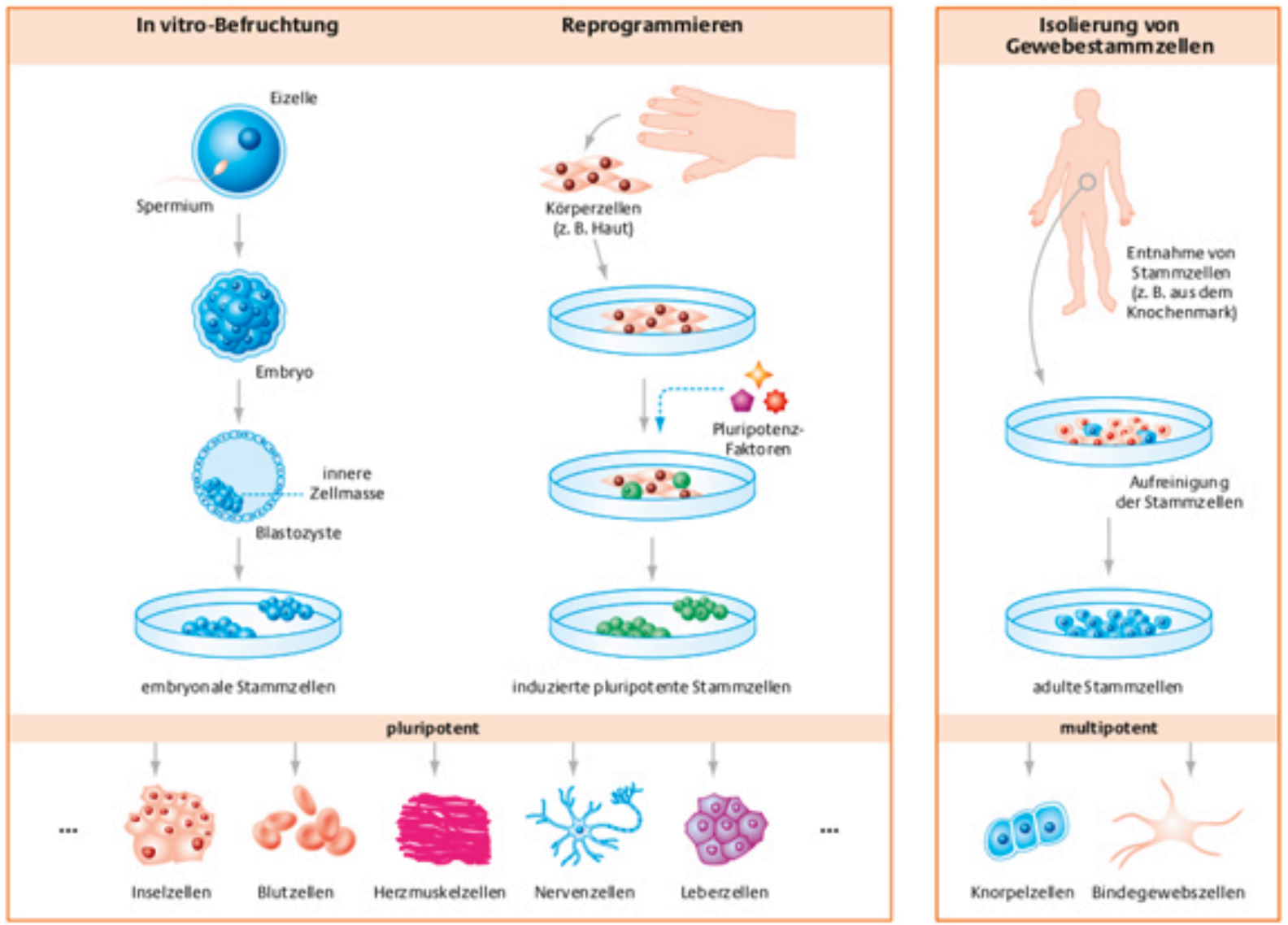

Abb. 3: Gewinnung und Kultivierung verschiedener Stammzellen.

Die Abbildung gibt einen Überblick über die Möglichkeiten der Gewinnung und Kultivierung von embryonalen, induziert pluripotenten und adulten Stammzellen. Außerdem zeigt sie die verschiedenen Differenzierungsmöglichkeiten der einzelnen pluripotenten bzw. multipotenten Zelltypen (http://www.biotechnologie.de/BIO/Redaktion/Bilder/de/Dossier/Regmed/wie-stammzellen-gewonnenwerden, property=bild, bereich=bio,sprache=de.jpg). 
In den darauffolgenden Jahren wurde versucht, die Sicherheit und Effizienz durch die Verwendung von nicht-integrierenden Vektoren bei der iPS-Generierung zu verbessern. Hierfür wurden adenovirale (Stadtfeld et al. 2008), episomale (Yu et al. 2009) und Sendai Vektoren (Fusaki et al. 2009) verwendet. 2009 beschrieben Sommer et al. einen lentiviralen Vektor, der OCT4, SOX2, KLF4 und C-MYC als Reprogrammierungsfaktoren in einer einzelnen stem cell cassette (STEMCCA) enthält. Dieses System ermöglicht bei reduzierter viraler, genomischer Integration eine effiziente Reprogrammierung. Außerdem ist es möglich die Kassette nach der Transduktion zu exzidieren (Sommer et al. 2009, 2010; Somers et al. 2010). Auch die Verwendung von synthetischer messenger ribonucleic acid (mRNA) (Warren et al. 2010) und mikro-RNA (miRNA) (Anokye-Danso et al. 2011) ergab in den letzten Jahren eine erfolgreiche Generierung von iPS.

Die induziert pluripotenten Stammzellen können ihrerseits Gene und Faktoren exprimieren, die sie als ES-ähnlich charakterisieren (Takahashi \& Yamanaka 2006; Maherali et al. 2007; Okita et al. 2007; Wernig et al. 2007).

Die Ähnlichkeit von miPS mit mES konnte anhand der Genexpression (Okita et al. 2007), DNA-Methylierung (Maherali et al. 2007) und Histon Modifikation (Wernig et al. 2007) größtenteils gezeigt werden. Außerdem besaßen die iPS die Fähigkeit, sich in sämtliche Zellen der drei Keimblätter zu differenzieren (Okita et al. 2007), weshalb sich zur weiteren Charakterisierung der iPS der Nachweis von Keimblattmarkern eignete.

Auch wenn sich daraus ein hohes medizinisches Potenzial und beachtliche Implikationen für die regenerative Medizin ergeben, da u.a. auch die Forschung an innen mit weniger ethischen Problemen behaftet ist als die an ES, ist letztendlich unklar, ob sich iPS von ES bei der klinischen Anwendung unterscheiden. 


\subsubsection{Zell-basierte Therapie der Herzregeneration - Stand der Technik}

Doch welche Quelle soll für Zell-basierte kardiale Regeneration verwendet werden?

Bereits 1999 wurde mit transplantierten fetalen Kardiomyozyten die Bildung eines neuen und voll entwickelten Myokards mit der Fähigkeit zur elekromechanischen Kopplung mit dem geschädigten Wirts-Myokard der Ratte erreicht. Allerdings sahen die Autoren für eine optimale Wiederherstellung das Problem einer zu starken Isolierung des Transplantats durch Narbengewebe und die geringe Verfügbarkeit der fetalen Kardiomyozyten (Reinecke et al. 1999).

Eine weitere Strategie war die Injektion von autologen Skelettmyoblasten (Menasché 2007). Myoblasten zeigen eine Ischämie-Resistenz und können sich in vivo in Myotuben entwickeln, jedoch nicht in Kardiomyozyten (Laflamme \& Murry 2005). In Tierexperimenten zeigte sich, dass sie die ventrikuläre Funktion verbessern können (Menasché 2007). Es zeigte sich jedoch auch, dass keine elektrische Integration der Myotuben mit den überlebenden Kardiomyozyten erfolgte und somit keine synchrone Kontraktion mit der myokardialen Umgebung stattfand (Laflamme \& Murry 2005; Segers \& Lee 2008).

Die ersten Zellen, bei denen nach Transplantation in infarzierte Mäuseherzen eine Differenzierung in Kardiomyozyten gezeigt werden konnte, waren KnochenmarkStammzellen (Leri et al. 2005). 2002 konnten Quaini et al. zeigen, dass adulte Knochenmark-abstammende Vorläuferzellen in erwachsenen, humanen Herzen an der Genese von Kardiomyozyten beteiligt sind (Quaini et al. 2002). Es folgten Tierexperimente, bei denen Knochenmark mit markierten hämatopoetischen Stammzellen in Tiere mit Myokardinfarkt transplantiert wurde. Hierbei ergab sich ein sehr geringer Anteil an Kardiomyozyten, die von den transplantierten Zellen abstammten (Jackson et al. 2001). Unabhängig davon zeigten jedoch zahlreiche weitere Studien weder eine kardiomyozytäre Differenzierung von hämatopoetischen Vorläuferzellen, noch eine Verbesserung der kardialen Funktion (Murry et al. 2004; Balsam et al. 2004; Leri et al. 2005; Stuckey et al. 2006).

Auch Guan und Hasenfuss sahen bei ihrer Beurteilung klinischer Daten nur einen geringen Benefit für den Patienten, wenn Stammzellen aus Knochenmark und Myoblasten eingesetzt werden. Die myokardiale Regeneration verlangt die Bildung von Kardiomyozyten, vaskulären Endothelzellen und glatten Muskelzellen, was am 
ehesten mit multipotenten Zellen wie z.B. ES zu erreichen sein dürfte (Guan \& Hasenfuss 2007).

Eine weitere Quelle, mit der beispielsweise u. a. auch eine immunologische Abstoßungsreaktion umgangen werden könnte, stellen endogene kardiale Stammzellen dar. Es gibt einen kleinen Anteil an myokardialen Stammzellen, die bei Säugetieren vorkommen und den Oberflächenmarker (tyrosine-protein kinase Kit) (Kit) (Beltrami et al. 2003) oder stem cell antigen-1 (Sca1) exprimieren. Dies würde eine Möglichkeit bieten, um diese Zellen zu isolieren. Es konnte gezeigt werden, dass aus Kit- und/oder Sca1- positiven Zellen sowohl in vitro, als auch in vivo Kardiomyozyten generiert werden können (Mouquet et al. 2005). Neben den genannten Markern konnte eine weitere Population kardialer Stammzellen ausgemacht werden, die eine Expression des Transkriptionsfaktors Insulin gene enhancer protein (IsI1) zeigte (Laugwitz et al. 2005). Weitere Experimente zeigten, dass Isl1-positive Zellen sich in endotheliale, endokardiale, Reizleitungszellen, rechtsventrikuläre, atriale und Zellen der glatten Muskulatur während der embryonalen Herzentwicklung differenzieren können (Moretti et al. 2006). Die Isl1positiven Zellen finden sich auch in adulten Säugerherzen, sie sind jedoch auf den rechten Vorhof beschränkt und in deutlich geringerer Zahl vorhanden als in embryonalen Herzen. Außerdem ist ihre physiologische Funktion unklar (Laugwitz et al. 2005). Auch bei der Therapie mit kardialen Stammzellen bleiben noch zahlreiche Fragen unbeantwortet. Kann ihr in vitro gezeigtes Proliferations- und Differenzierungspotenzial auch längerfristig in vivo funktionieren? Und inwiefern behalten die Zellen ihr kardiogenes Potenzial auch in pathologischen bzw. gealterten Herzen (Segers \& Lee 2008) (Abb. 4)? 


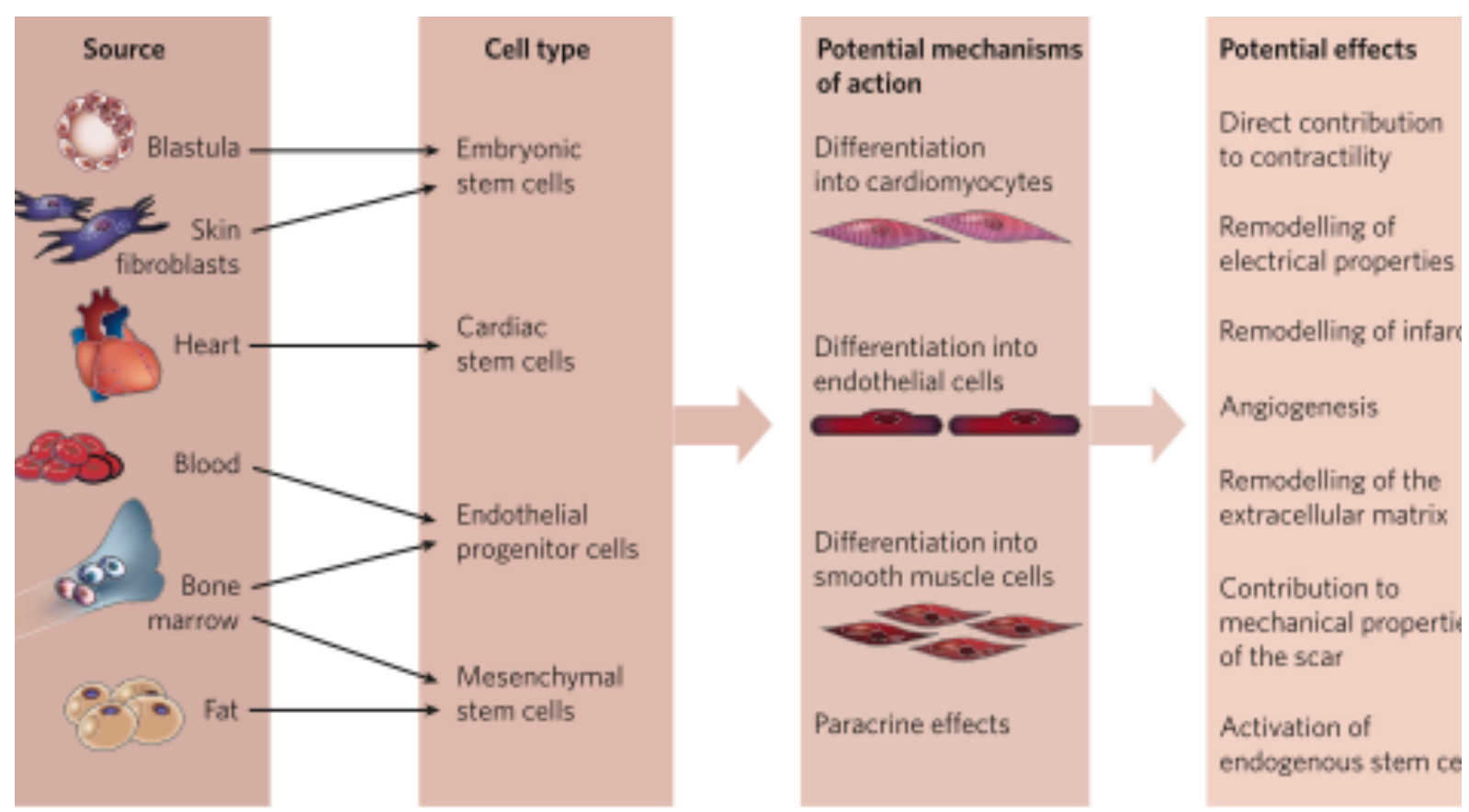

Abb. 4: Für die kardiale Therapie zur Verfügung stehende Zelltypen und Mechanismen.

Stamm- und Vorläuferzellen können aus autologen oder allogenen Quellen gewonnen werden. Es konnte gezeigt werden, dass verschiedene Typen von Stamm- und Vorläuferzellen die kardiale Funktion durch verschiedene Mechanismen verbessern können. Hierzu zählt die Neuformation von Myozyten, Endothel- und glatten Muskelzellen sowie der Einfluss parakriner Effekte (Segers \& Lee 2008).

Die in dieser Dissertation untersuchten Zellen könnten eine weitere Option der Zelltherapie bei strukturellen Herzerkrankungen sein. Es handelt sich um ES und iPS der Maus. Zu der Vielzahl verschiedener Zellarten, die zur Regenerierung von geschädigtem Herzmuskelgewebe eingesetzt werden, gehören auch die zu Kardiomyozyten differenzierten ES (Guan \& Hasenfuss 2007; Rubart \& Field 2008).

ES und iPS sind pluripotente Zellen, die ein unbegrenztes Fortpflanzungspotenzial besitzen und sowohl in vitro als auch in vivo in Zellen aller drei Keimblätter differenzieren (Yoshida \& Yamanaka 2011). In Tiermodellen zahlreicher Erkrankungen konnten bereits therapeutische Effekte durch humane ES und iPS dargestellt werden (Keirstead et al. 2005; Laflamme et al. 2007; Yang et al. 2008; Lamba et al. 2009). 2009 konnte gezeigt werden, dass nach intramyokardialer Applikation von murinen iPS die Regeneration des kardialen Gewebes und zusätzlich die postischämische kardiale Funktion verbessert werden konnte (Nelson et al. 2009). Durch ein mäßiges Überleben wird jedoch eine adäquate Integration der transplantierten Zellen im Myokard des Empfängers verhindert (Yoshida \& 
Yamanaka 2011). Es gibt jedoch Arbeiten, die zeigen, dass eine Transplantation von in vitro kultivierten Kardiomyozytenaggregaten das Überleben der transplantierten Zellen verbessert (Shimizu et al. 2006; Hattori et al. 2010). Letztendlich müssen jedoch für die Anwendung am Menschen mehrere Probleme gelöst werden, bevor man ES bzw. iPS therapeutisch nutzen kann: Die generierten iPS sollten keine genomische Integration des retroviralen Vektors zeigen (Takahashi \& Yamanaka 2006), und C-Myc als ein Bestandteil des Vektors sollte vermieden werden. Das Regulatorgen c-Myc ist als Onkogen bekannt und kann somit für eine Tumorgenese verantwortlich sein (Okita et al. 2007). Ferner ist man mit dem Problem der immunologischen Abstoßungsreaktion des Empfängers und mit der Eigenschaft pluripotenter Zellen, in vivo Teratome zu bilden, konfrontiert (Laflamme \& Murry 2005; Nussbaum et al. 2007). Zumindest die immunologische Komponente könnte durch die Verwendung von Empfänger-eigenen iPS umgangen werden.

Neben der Verwendung von iPS bei der Zellersatztherapie gibt es noch weitere Anwendungsmöglichkeiten der iPS-Technologie im Zusammenhang mit der Herzinsuffizienz. Das Screening auf Patienten-spezifische Arzneimitteltherapie, toxikologische Tests und das Erstellen von Modellen monogenetischer bzw. komplexer Erkrankungen zur Analyse molekularer bzw. pathophysiologischer Prozesse sind nur einige Beispiele (Chun et al. 2011).

\section{$1.3 \quad$ Zielsetzung}

Das Ziel dieser Dissertation war es, die für diese Arbeit generierten iPS bezüglich ihrer Morphologie, Proliferation und Pluripotenz zu charakterisieren, die Zellen in Kardiomyozyten zu differenzieren und gleichzeitig mittels des myosin heavy chain (MHC)-gekoppelten Fluoreszenzfarbstoffes enhanced green fluorescence protein (eGfp) sichtbar zu machen, um somit ihre Morphologie analysieren zu können. Des Weiteren wurden die iPS-Linien mit einer ES-Linie in sämtlichen untersuchten Eigenschaften verglichen.

Zur Identifizierung geeigneter muriner Zelllinien wurden im Vorfeld meiner Arbeit aus Fibroblasten zweier doppelt-transgener Mäuse iPS mit Hilfe einer lentiviralen STEMCCA mit den vier Reprogrammierungsfaktoren OCT4, SOX2, KLF4 und C-MYC (Sommer et al. 2009) generiert, die im Rahmen dieser Dissertation mit einer ebenfalls doppelt-transgenen mES-Linie verglichen werden sollten. Denn auch wenn 
das Differenzierungspotenzial der iPS gegenüber der ES als äquivalent angesehen wird, konnte dies noch nicht endgültig bewiesen werden (Schenke-Layland et al. 2008). Um sich diesem Beweis anzunähern, wurden die Zelllinien im pluripotenten Zustand bezüglich ihrer Proliferation, ihres Karyotyps und ihrer Pluripotenz analysiert. Die Zellen wurden mittels hanging drop-Methode in Kardiomyozyten differenziert, selektiert und letztendlich quantitativ, morphologisch und anhand kardialer Marker charakterisiert. 


\section{Material und Methoden}

\subsection{Zelllinien}

Die verwendeten folgenden Zelllinien stammten aus dem Stammzelllabor der Abteilung Kardiologie/Pneumologie der Universitätsmedizin Göttingen, Robert-Koch Str. 40, 37075 Göttingen.

la*: MEFs der doppelt transgenen Maus I (Mhc-Neo/Mhc-eGfp, siehe 2.5) mit Dilute Brown Non-Agouti-Hintergrund (DBA) (siehe 2.6.3). Sie wurden als Kontrolle bei der epigenetischen Analyse verwendet.

IMOI1: Im Vorfeld dieser Arbeit generierte miPS, gewonnen aus MEFs (la*) der doppelt transgenen Maus I mit DBA-Hintergrund mittels Transduktion des lentiviralen STEMCCA-Virus (siehe 2.6.3). Zur Verfügung gestellt von Dr. A. Becker (Abteilung Kardiologie/Pneumologie der Universitätsmedizin Göttingen).

V1*: MEFs der doppelt transgenen Maus V (Mhc-Neo/Mhc-eGfp, siehe 2.5) mit DBAHintergrund (siehe 2.6.3). Sie wurden als Kontrolle bei der epigenetischen Analyse verwendet.

VMOI1: miPS, gewonnen aus MEFs $\left(\mathrm{V}^{*}\right)$ der doppelt transgenen Maus $\mathrm{V}$ mit DBAHintergrund mittels Transduktion des lentiviralen STEMCCA-Virus (siehe 2.6.3). Zur Verfügung gestellt von Dr. A. Becker.

ES-7: mES, isoliert aus der Blastozyste einer doppelt transgenen Mhc-Neo/MhceGfp-DBA-Maus (siehe 2.6.2). Zur Verfügung gestellt von Dr. A. Becker.

ES-9: eGfp-freie murine ES-Linie isoliert aus der Blastozyste einer DBA-Maus (siehe 2.6.2).

MPI-II: mES namens Max Planck Institut II, die als Positivkontrolle bei der mRNAAnalyse der Pluripotenzmarker dienten und von Prof. P. Gruss (Max Planck Institut für biophysikalische Chemie) zur Verfügung gestellt wurden. 
MEF: In dieser Arbeit generierte MEFs aus NMRI-Maus-Embryonen zur Kokultivierung der mES und miPS (siehe 2.6.1).

\subsection{Medien, Lösungen und Substanzen}

\begin{tabular}{|c|c|}
\hline DPBS: & $\begin{array}{l}\text { Dulbeccos Phosphat- gepufferte } \\
\text { Salzlösung 1x (DPBS, Life Technologies, } \\
\text { 14190) }\end{array}$ \\
\hline BSA-Lösung: & $\begin{array}{l}\text { 7,5\% Rinderserumalbumin (BSA, Gibco, } \\
15260-037) \text { mit } 1 \times \text { DPBS auf } \\
\text { gewünschten Gehalt verdünnt }(0,1-4 \%)\end{array}$ \\
\hline DMEM/F 12: & $\begin{array}{l}\text { Dulbeccos modifiziertes Eagle } \\
\text { Medium/F12 + GlutaMAX }{ }^{\mathrm{TM}} \text { (Life } \\
\text { Technologies, 32331) }\end{array}$ \\
\hline Kollagenase IV: & $\begin{array}{l}\text { Kollagenase IV (Worthington } \\
\text { Biochemicals Corp.) angesetzt in } \\
\text { DMEM/F12 (2000 U/ml), aliquotiert, } \\
\text { Lagerung bei }-20^{\circ} \mathrm{C} \text {. Vor Gebrauch } 1: 10 \\
\text { Verdünnung mit DMEM/F12 auf } 200 \\
\text { U/ml }\end{array}$ \\
\hline $\begin{array}{l}\text { 4',6-Diamidino-2-phenylindole (DAPI) 0,4 } \\
\mu \mathrm{g} / \mathrm{ml} \text { : }\end{array}$ & $\begin{array}{l}\text { Stocklösung (2 mg/ml), } 5 \mathrm{mg} \text { DAPI } \\
\text { (Sigma) in } 2,5 \mathrm{ml} \text { entionisiertem Wasser } \\
\text { gelöst. Vorverdünnung } 1: 100 \text { in DPBS } \\
\text { dann weitere Verdünnung von } 1: 50 . \\
\text { Lagerung in lichtundurchlässiger Box bei } \\
4^{\circ} \mathrm{C}\end{array}$ \\
\hline DMEM: & $\begin{array}{l}\text { Dulbeccos modifiziertes Eagle Medium } \\
\text { mit } 4,5 \mathrm{~g} / \mathrm{l} \text { Glucose (Life Technologies, } \\
11960 \text { ) }\end{array}$ \\
\hline Demecolcin-Stammlösung: & 10 g/ml Demecolcin-Lösung (Sigma) \\
\hline 5x TB-Puffer (1000 ml): & $\begin{array}{l}54 \mathrm{~g} \text { Tris (Roth, } 5429.3), 27,5 \mathrm{~g} \text { Borsäure } \\
\text { (Sigma, 15663) in } 1000 \mathrm{ml} \text { Aqua dest. }\end{array}$ \\
\hline 1\% DNA-Agar-Gel: & $\begin{array}{l}1 \text { g DNA-Agar (Serva) in } 100 \mathrm{ml} \text { 1x TB- } \\
\text { Puffer unter Hitze lösen und } 5-7 \mu \mathrm{ll} 1 \% \\
\text { Ethidium-Bromid-Lösung } \\
\text { hinzufügen }\end{array}$ \\
\hline
\end{tabular}




\begin{tabular}{|c|c|}
\hline 6x DNA-Ladepuffer: & $\begin{array}{l}\text { 0,25\% Bromphenolblau (Sigma, B7021), } \\
0,25 \% \text { Xylencyanol (Sigma, X4126) und } \\
30 \% \text { Glycerin (Sigma, G7043) in Aqua } \\
\text { dest. }\end{array}$ \\
\hline 50x EDTA-Lösung: & $\begin{array}{l}1 \mathrm{~g} \text { Ethylendiamintetraessigsäure } \\
\text { (EDTA, Sigma, E6758) in } 100 \mathrm{ml} \text { DPBS } \\
\text { gelöst, } \mathrm{pH}=7,0 \text {, steril filtriert, Lagerung } \\
\text { bei } 4^{\circ} \mathrm{C}\end{array}$ \\
\hline Einfrier-Medium: & $\begin{array}{l}\text { DMEM, } 20 \% \text { fetales Kälberserum (FKS, } \\
\text { Lonza, F-6SB0011, durch Hitze für } 30 \\
\text { min bei } 56^{\circ} \mathrm{C} \text { inaktiviert) (Lonza), } 8 \% \\
\text { DMSO (Sigma) }\end{array}$ \\
\hline 100x Glutamin: & 200 mM L-Glutamin (Gibco) \\
\hline FL-Medium: & $\begin{array}{l}\text { DMEM mit 15\% FKS, 1x Glutamin (Life } \\
\text { Technologies, 25030) }\end{array}$ \\
\hline G418 (Geneticin)-Sulfat: & $\begin{array}{l}\text { Stocklösung }(100 \mathrm{mg} / \mathrm{ml}), 100 \mathrm{mg} \\
\text { G418-Sulfat (Clontech) in } 1 \mathrm{ml} \\
\text { entionisiertem Wasser lösen, steril } \\
\text { filtrieren, Lagerung bei } 4^{\circ} \mathrm{C}\end{array}$ \\
\hline 0,02\% Giemsa-Färbung (modifiziert): & $\begin{array}{l}10 \mathrm{ml} \text { 0,4\% Giemsa-Färbung } \\
\text { (Accustain), modifiziert (Sigma) mit } 190 \\
\text { ml Aqua dest. }\end{array}$ \\
\hline 100x $\beta$-ME-Stammlösung: & $\begin{array}{l}7 \mu \mathrm{ll} \beta \text {-Mercaptoethanol ( } \beta \text {-ME, Promega, } \\
\text { Z523C) in } 10 \mathrm{ml} 1 \times \text { DPBS, steril filtriert }\end{array}$ \\
\hline LIF: & $\begin{array}{l}10^{3} \mathrm{U} / \mu \mathrm{l} \text { Leukemia Inhibitory Factor (LIF; } \\
\text { Chemicon, 1107) }\end{array}$ \\
\hline FlII-Medium: & $\begin{array}{l}\text { MEM Alpha Medium mit 4,5\% FKS, 4,5\% } \\
\text { KOSR, 1x B-ME, 0,35\% D-(+)-Glucose } \\
\text { (Sigma, G8769), 103 U/ml LIF }\end{array}$ \\
\hline hbFGF: & $\begin{array}{l}\text { human basic fibroblast growth factor } \\
\text { (hbFGF, Peprotech, } 100-18 \text { ), } \\
\text { Stocklösung: } 10 \mu \mathrm{g} \text { hbFGF in } 200 \mu \mathrm{ll} \\
\text { DPBS mit } 0,1 \% \mathrm{BSA} \text { gelöst, aliquotiert, } \\
\text { Lagerung bei }-20^{\circ} \mathrm{C} \text {. Zum Gebrauch auf } \\
5 \mathrm{ng} / \mu \mathrm{l} \text { in } 0,1 \% \mathrm{BSA} \text { verdünnt }\end{array}$ \\
\hline MTG-Lösung: & $\begin{array}{lllll}1 & \mathrm{ml} \text { Iscove-Medium } & \text { mit } 13 & \mu \mathrm{l} \\
\text { Monothioglycerol (MTG, } & \text { Sigma, } & \text { M- } \\
\text { 6145), steril filtriert }\end{array}$ \\
\hline
\end{tabular}




\begin{tabular}{|c|c|}
\hline $\begin{array}{l}\text { 100x MEM nicht } \\
\text { Aminosäuren (NEAA): }\end{array}$ & 10 mM MEM NEAA (Gibco) \\
\hline Iscove-Medium: & 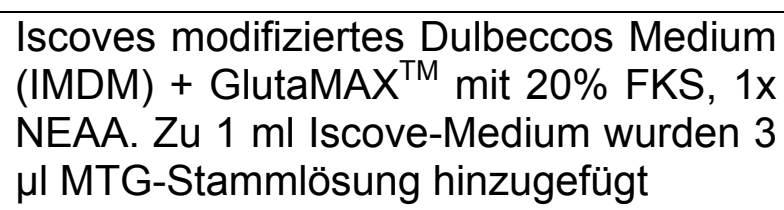 \\
\hline 0,4\% KCl-/ 0,4\% Natrium-Zitrat-Lösung: & $\begin{array}{l}400 \mathrm{mg} \mathrm{KCl} \text { (Roth) und } 400 \mathrm{mg} \text { Tris- } \\
\text { Natrium-Zitrat-Dihydrat (Roth) in } 100 \mathrm{ml} \\
\text { entionisiertem Wasser lösen, Lagerung } \\
\text { bei RT }\end{array}$ \\
\hline KMSZ-Medium: & 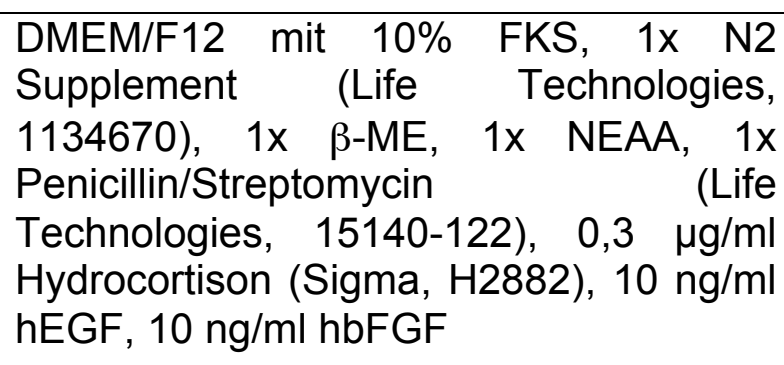 \\
\hline mES-Medium: & $\begin{array}{l}\text { DMEM mit } 15 \% \text { FKS, 1x Glutamin, 1x } \\
\text { NEAA (Life Technologies, 11140-035), } \\
1 \times \beta-M E, 10^{3} \mathrm{U} / \mathrm{ml} \text { LIF (Chemicon, 1107) }\end{array}$ \\
\hline MMC-Lösung $(200 \mu \mathrm{g} / \mathrm{ml})$ : & $\begin{array}{l}2 \mathrm{mg} \text { Mitomycin C }(\mathrm{MMC} \text {, Serva, } \\
29805.02) \text { in } 10 \mathrm{ml} \text { DPBS gelöst, } \\
\text { aliquotiert, Lagerung bei }-20^{\circ} \mathrm{C}\end{array}$ \\
\hline hEGF: & $\begin{array}{l}\text { human epidermal growth factor (hEGF, } \\
\text { Peprotech, } 100-15 \text { ), Stocklösung: } 0,1 \mathrm{mg} \\
\text { hEGF in } 100 \mu \mathrm{ll} \text { DPBS mit } 0,1 \% \mathrm{BSA} \\
\text { gelöst, aliquotiert, Lagerung bei }-20^{\circ} \mathrm{C} \text {. } \\
\text { Zum Gebrauch auf } 10 \mathrm{ng} / \mathrm{\mu l} \text { in } 0,1 \% \mathrm{BSA} \\
\text { verdünnt }\end{array}$ \\
\hline 100x Penicillin/Streptomycin-Lösung: & $\begin{array}{l}\text { (Sigma, P4333), } \\
\text { Gebrauchskonzentration 1x in jeweiligem } \\
\text { Medium }\end{array}$ \\
\hline 4\% PFA-Lösung: & $\begin{array}{l}\text { 4\% Paraformaldehyd (PFA, Sigma, } \\
\text { P6148) unter Hitze gelöst in DPBS }\end{array}$ \\
\hline Hexadimethrin-Bromid (Polybrene) & $\begin{array}{l}\text { Stammlösung }(1 \mathrm{mg} / \mathrm{ml}): 1 \mathrm{mg} \text { Polybrene } \\
\text { (Sigma) in } 1 \mathrm{ml} \text { Aqua dest. Iösen, steril } \\
\text { filtrieren, bei } 4^{\circ} \mathrm{C} \text { lagern. }\end{array}$ \\
\hline RNA-Lysis-Puffer (10 ml): & \begin{tabular}{lllll}
$9,8 \quad \mathrm{ml}$ & \multicolumn{2}{c}{ RNA-Lysis-Puffer } & (Promega, \\
Z305E) mit $\quad 200$ & Hl & $48,7 \%$ & $\beta-\mathrm{ME}$ \\
(Promega, Z523C) & & &
\end{tabular} \\
\hline
\end{tabular}




\begin{tabular}{|l|l|}
\hline $0,1 \%$ Gelatinelösung: & $\begin{array}{l}1 \% \text { Gelatine (Fluka Biochemica, 48720) } \\
\text { in Aqua dest., autoklaviert und 1:10 mit } \\
\text { Aqua dest. verdünnt }\end{array}$ \\
\hline $0,1 \%$ Triton-X-100 (T-X-100): & $\begin{array}{l}10 \mu \mathrm{ll} \text { T-X-100 (Sigma) in } 990 \mu \mathrm{LPBS} \\
\text { lösen um 1\% T-X-100 zu bekommen, } \\
\text { dann 1:10 in DPBS endverdünnen. }\end{array}$ \\
\hline $0,2 \%$ Trypsin-Lösung: & $\begin{array}{l}2 \mathrm{~g} \text { Trypsin (Life technologies, 27250- } \\
018) \text { in } 1000 \mathrm{ml} \text { DPBS gelöst, steril } \\
\text { filtriert, Lagerung bei -20 } \mathrm{C}\end{array}$ \\
\hline $0,1 \%$ Trypsin/EDTA-Lösung (T/E): & $\begin{array}{l}50 \mathrm{ml} 0,2 \% \text { Trypsin-Lösung, 49 ml } \\
\text { DPBS, } 1 \mathrm{ml} 50 x \text { EDTA-Lösung }\end{array}$ \\
\hline $0,05 \%$ Trypsin/EDTA-Lösung (T/E): & $\begin{array}{l}50 \mathrm{ml} 0,1 \% \text { Trypsin/EDTA-Lösung, } 50 \mathrm{ml} \\
\text { DPBS }\end{array}$ \\
\hline
\end{tabular}

\subsection{Oligonukleotide}

Die verwendeten Oligonukleotide bzw. Primer stammen von der Firma MWG Eurofins Operon. Die Iyophilisierten Primer wurden in Aqua dest. gelöst und bei $20^{\circ} \mathrm{C}$ gelagert. Die Vorwärtssequenzen (f) und Rückwärtssequenzen ( $r$ ), Annealingtemperaturen $\left(T_{A}\right)$, Fragmentlänge $(F)$ sowie die Zyklenanzahl $(Z)$ sind in Tab. 1 dargestellt.

Tab. 1: Oligonukleotide

\begin{tabular}{|l|l|l|l|l|}
\hline Gen & Vorwärts- und Rückwärtssequenzen & $\left.\mathrm{T}_{\mathbf{A}} \mathbf{(}^{\circ} \mathbf{C}\right)$ & $\mathbf{F}$ (bp) & $\mathbf{Z}$ \\
\hline $\begin{array}{l}\text { KLF4/ } \\
\text { IRES }\end{array}$ & $\begin{array}{l}\text { f A141: 5'-GTC TTG AGG AAG TGC TGA G-3' } \\
\text { r B106: 5'-AGA GGA ACT GCT TCC TTC ACG } \\
\text { ACA-3' }\end{array}$ & 55 & 600 & 32 \\
\hline Afp & $\begin{array}{l}\text { f F91: 5'-CCC ACC CTT CCA GTT TCC-3' } \\
\text { r F92: 5'-TCG TAC TGA GCA GCC AAG G-3' }\end{array}$ & 58 & 150 & 37 \\
\hline Anf & $\begin{array}{l}\text { f F67: 5'-TGA TAG ATG AAG GCA GGA AGC } \\
\text { CGC-3' } \\
\text { r F68: 5'-AGG ATT GGA GCC CAG AGT GGA } \\
\text { CTA GG-3' }\end{array}$ & $\begin{array}{l}\text { f' F51: 5'-CTG CTG GAG AGG TTA TTC CTC G- } \\
\text { r F52: 5'-GGA AGA GTG AGC GGC GCA TCA } \\
\text { AGG-3' }\end{array}$ & 203 & 33 \\
\hline $\boldsymbol{\alpha - M h c}$ & 301 & 32 \\
\hline
\end{tabular}




\begin{tabular}{|c|c|c|c|c|}
\hline Gapdh & $\begin{array}{l}\text { f A79: 5'-GCA GTG GCA AAG TGG AGA TT-3' } \\
\text { r A80: 5'-TCT CCA TGG TGG TGA AGA CA-3' }\end{array}$ & 56 & 249 & 31 \\
\hline Gata4 & $\begin{array}{l}\text { f K47: 5'-CTG TCA TCT CAC TAT GGG CA-3' } \\
\text { r K48: 5'-CCA AGT CCG AGC AGG AAT TT-3' }\end{array}$ & 57 & 257 & 34 \\
\hline Lin28 & $\begin{array}{l}\text { f B130: 5'-TCC TCC TGT GTC TCC CAT TC-3' } \\
\text { r B131: 5'-AGA GTG AGG CCC TGT CTC AA-3' }\end{array}$ & 59 & 214 & 36 \\
\hline Mash1 & $\begin{array}{l}\text { f F131: 5'-CTC GTC CTC TCC GGA ACT GAT } \\
\text { G-3' } \\
\text { r F132: 5'-CGA CAG GAC GCC GCG CTG AAA } \\
\text { G-3' }\end{array}$ & 64 & 301 & 38 \\
\hline MIc2v & $\begin{array}{l}\text { f F57: 5'-TGT GGG TCA CCT GAG GCT GTG } \\
\text { GTT CAG-3' } \\
\text { r F58: 5'-GAA GGC TGA CTA TGT CCG GGA } \\
\text { GAT GC-3' }\end{array}$ & 60 & 189 & 30 \\
\hline Nanog & $\begin{array}{l}\text { f F41: 5'-AGG GTC TGC TAC TGA GAT GCT } \\
\text { CGT-3' } \\
\text { r F42: 5'-CAA CCA CTG GTT TTT CTG CCA } \\
\text { CCG-3' }\end{array}$ & 66 & 363 & 34 \\
\hline Nkx2.5 & $\begin{array}{l}\text { f K45: 5'-CAG TGG AGC TGG ACA AAG CC-3' } \\
\text { r K46: 5'-TAG CGA CGG TTC TGG AAC CA-3' }\end{array}$ & 65 & 217 & 35 \\
\hline Oct4 & $\begin{array}{l}\text { f F37: 5'-GGC GTT CTC TTT GGA AAG GTG } \\
\text { TTC-3' } \\
\text { r F38: 5'-CTC GAA CCA CAT CCT TCT CT-3' }\end{array}$ & 61 & 312 & 38 \\
\hline $\operatorname{Rex1}$ & $\begin{array}{l}\text { f F59: 5'-GGC CAG TCC AGA ATA CCA GA-3' } \\
\text { r F60: 5'-GAA CTC GCT TCC AGA ACC TG-3' }\end{array}$ & 59 & 232 & 28 \\
\hline
\end{tabular}

\subsection{Antikörper}

Die spezifischen Epitope, die verwendete Verdünnung und die Herkunft der zur Immunfluoreszenz-Analyse verwendeten primären und sekundären Antikörper sind in den Tab. 2 und 3 aufgeführt.

Tab. 2: Primärantikörper

\begin{tabular}{|l|l|l|l|l|}
\hline Antigen & Klon & Spezies/lsotyp & Herkunft & Verdünnung \\
\hline a-Actinin & BM75.2 & Monoklonal Maus IgM & $\begin{array}{l}\text { Sigma } \\
\text { A5044 }\end{array}$ & $1: 500$ \\
\hline Nanog & - & Polyklonal Kaninchen IgG & $\begin{array}{l}\text { Abcam } \\
\text { ab80892 }\end{array}$ & $1: 500$ \\
\hline Oct4 & - & Polyklonal Kaninchen IgG & $\begin{array}{l}\text { Abcam } \\
\text { ab19857 }\end{array}$ & $1: 500$ \\
\hline Sox2 & - & Polyklonal Kaninchen IgG & $\begin{array}{l}\text { Abcam } \\
\text { ab97959 }\end{array}$ & $1: 500$ \\
\hline SSEA-1 & MC480 & Monoklonal Maus IgM & $\begin{array}{l}\text { Abcam } \\
\text { ab16285 }\end{array}$ & $1: 100$ \\
\hline
\end{tabular}


Tab. 3: Sekundärantikörper

\begin{tabular}{|l|l|l|l|}
\hline Fluoreszenz & Typ & Herkunft & Verdünnung \\
\hline Alexa Fluor 555 & $\begin{array}{l}\text { Ziege-anti-Maus } \\
\text { lgM }\end{array}$ & $\begin{array}{l}\text { Life Technologies } \\
\text { A21426 }\end{array}$ & $1: 200$ \\
\hline $\mathbf{C y}^{3}$ & $\begin{array}{l}\text { Ziege-anti-Maus } \\
\text { IgG+IgM }\end{array}$ & $\begin{array}{l}\text { Jackson } \\
\text { ImmunoResearch } \\
115-165-068\end{array}$ & $1: 500$ \\
\hline FITC & $\begin{array}{l}\text { Ziege-anti- } \\
\text { Kaninchen IgG }\end{array}$ & $\begin{array}{l}\text { Jackson } \\
\text { ImmunoResearch } \\
111-095-045\end{array}$ & $1: 200$ \\
\hline
\end{tabular}

\subsection{Versuchstiere: Mhc-Neo/Mhc-eGfp-Mäuse}

Die im Rahmen dieser Doktorarbeit durchgeführten Tierversuche wurden durch die Tierschutzbehörde des Landes Niedersachsen geprüft und genehmigt (Tierschutzantrag: 33.9.42502-04-060/09). Die Haltung der Tiere erfolgte in der Zentralen Tierexperimentellen Einrichtung (ZTE) der Universitätsmedizin Göttingen in einem 12-stündigen Hell-Dunkel-Rhythmus. Außerdem erhielten die Mäuse spezifisches Wasser und Futter.

Die doppelt transgenen Mhc-Neo/Mhc-eGfp-Mäuse besitzen eine NeomycinGeneticin-Antibiotikaresistenz (Neo) und weisen den Fluoreszenzfarbstoff eGfp auf. Diese werden über den kardialen Promotor Mhc reguliert. Die Tiere haben einen DBA-Hintergrund und wurden freundlicherweise von Prof. Dr. Loren J. Field (Indiana University School of Medicine, USA) zur Verfügung gestellt.

\subsection{Gewinnung und Kultivierung von mES und miPS}

Für die Zellkultur wurden sterile Materialien und Lösungen verwendet. Sämtliche Arbeiten wurden unter einer Umluft-Sterilbank (Heraeus Instruments) durchgeführt. Die Zellen wurden bei $37^{\circ} \mathrm{C}$ bei $95 \%$ Luftfeuchtigkeit und $5 \%$ Kohlenstoffdioxid in einem Inkubator der Firma Heraeus Instruments inkubiert. Die Zentrifugation der Zellen erfolgte für 5 Minuten bei $445 \mathrm{~g}$. Des Weiteren wurden täglich Morphologie, Dichte und Differenzierungsgrad der Zellen lichtmikroskopisch beurteilt. Das Mikroskop Zeiss Axio Observer A1 sowie das digitale Bildverarbeitungsprogramm Axio Vision 4.6 dienten für lichtmikroskopische Aufnahmen. 


\subsubsection{Gewinnung von mouse embryonic fibroblasts (MEFs)}

MEFs dienen der Bereitstellung von Faktoren, die den pluripotenten Zustand von miPS und mES aufrechterhalten.

Die Zellen wurden im Entwicklungsstadium E14,5-16 aus NMRI-Maus-Embryonen isoliert. Daraufhin wurden sie auf $10 \mathrm{~cm} \varnothing$ Zellkulturschalen (Cyto One) kultiviert und je nach Zelldichte alle zwei bis vier Tage umgesetzt. Es erfolgte täglich ein Mediumwechsel mit FL-Medium. Um das Zellwachstum zu stoppen, wurde dem FLMedium MMC (10 $\mu \mathrm{g} / \mathrm{ml})$ für 3-4 Stunden bei $37^{\circ} \mathrm{C}$ hinzugefügt. Hiernach wurden die MEFs 3x mit DPBS gewaschen und mit 0,2\% Trypsin verdaut. Nachdem die Zellen gezählt worden waren, wurden sie in der benötigten Anzahl auf mit 0,1\% Gelatine beschichteten Zellkulturschalen plattiert. Es wurden $3 \times 10^{5}$ Zellen auf eine $6 \mathrm{~cm} \varnothing$ Schale ausplattiert. Am Folgetag waren die MEFs zum Gebrauch bereit.

\subsubsection{Gewinnung von mES}

Die Generierung der murinen ES-Linie 7 (ES-7) erfolgte im Vorfeld dieser Arbeit durch die Entnahme der Blastozyste von doppelt transgenen (Mhc-Neo/Mhc-eGfp) Mäusen. Nach erfolgreicher Befruchtung wurde den Tieren nach 3,5 Tagen die Blastozyste entnommen und auf eine Zellkulturschale übertragen. Diese wurde nun 8 weitere Tage kultiviert, bis die ICM visuell vom Trophoektoderm abgrenzbar war und somit entnommen werden konnte. Die Zellen der ICM wurden auf eine weitere Zellkulturschale übertragen, einzelne morphologisch verwertbare Kolonien wurden gepickt und auf separaten Zellkulturschalen mit MEFs passagiert.

Der Nachweis des genetischen Hintergrundes erfolgte durch eine polymerase chain reaction (PCR)-Analyse mit eGfp- und Neomycin-Primern.

Die in der Durchflusszytometrie verwendete eGfp-freie murine ES-Linie 9 wurde ebenfalls aus der Blastozyste einer DBA-Maus isoliert. Die nachfolgende PCRAnalyse ergab keinen Nachweis für das Mhc-Neo/Mhc-eGfp Konstrukt. Die Zellen wurden freundlicherweise von Dr. A. Becker (Abteilung Kardiologie/Pneumologie der Universitätsmedizin Göttingen) zur Verfügung gestellt. 


\subsubsection{Gewinnung von miPS}

Die Generierung der miPS-Linien IMOI1 und VMOI1 erfolgte im Vorfeld dieser Arbeit mittels MEFs doppelt transgener (Mhc-Neo/Mhc-eGfp) Mäuse.

Die Zellen wurden im Entwicklungsstadium E14,5-16 aus DBA-Maus-Embryonen isoliert. Daraufhin wurden sie auf $10 \mathrm{~cm} \varnothing$ Zellkulturschalen (Cyto One) kultiviert und je nach Zelldichte alle zwei bis vier Tage umgesetzt. Es erfolgte täglich ein Mediumwechsel mit FL-Medium. Um das Zellwachstum zu stoppen, wurde dem FLMedium MMC (10 $\mu \mathrm{g} / \mathrm{ml})$ für 3-4 Stunden bei $37^{\circ} \mathrm{C}$ hinzugefügt. Hiernach wurden die MEFs 3x mit DPBS gewaschen und mit 0,2\% Trypsin verdaut. Nachdem die Zellen gezählt worden waren, wurden sie in der benötigten Anzahl auf mit 0,1\% Gelatine beschichteten Zellkulturschalen plattiert.

Um die gewonnenen MEFs in pluripotente Stammzellen mit Hilfe der vier Transkriptionsfaktoren OCT4, SOX2, c-MYC und KLF4 zu reprogrammieren (Wernig et al. 2007), wurden die isolierten MEFs mit dem lentiviralen STEMCCA-Virus transduziert (Abb. 5). Das humanisierte exzidierbare lentivirale STEMCCA System enthält die vier Reprogrammierungsfaktoren OCT4, SOX2, KLF4 und C-MYC in einer einzelnen stem cell cassette (pHAGE2-EF1aFull-hOct4-F2A-hKIf4-IRES-hSox2-P2AhcMyc-W-loxP) (Sommer et al. 2009; Somers et al. 2010). Sie wurde freundlicherweise von Prof. Darrell Kotton der Universität Boston zur Verfügung gestellt.

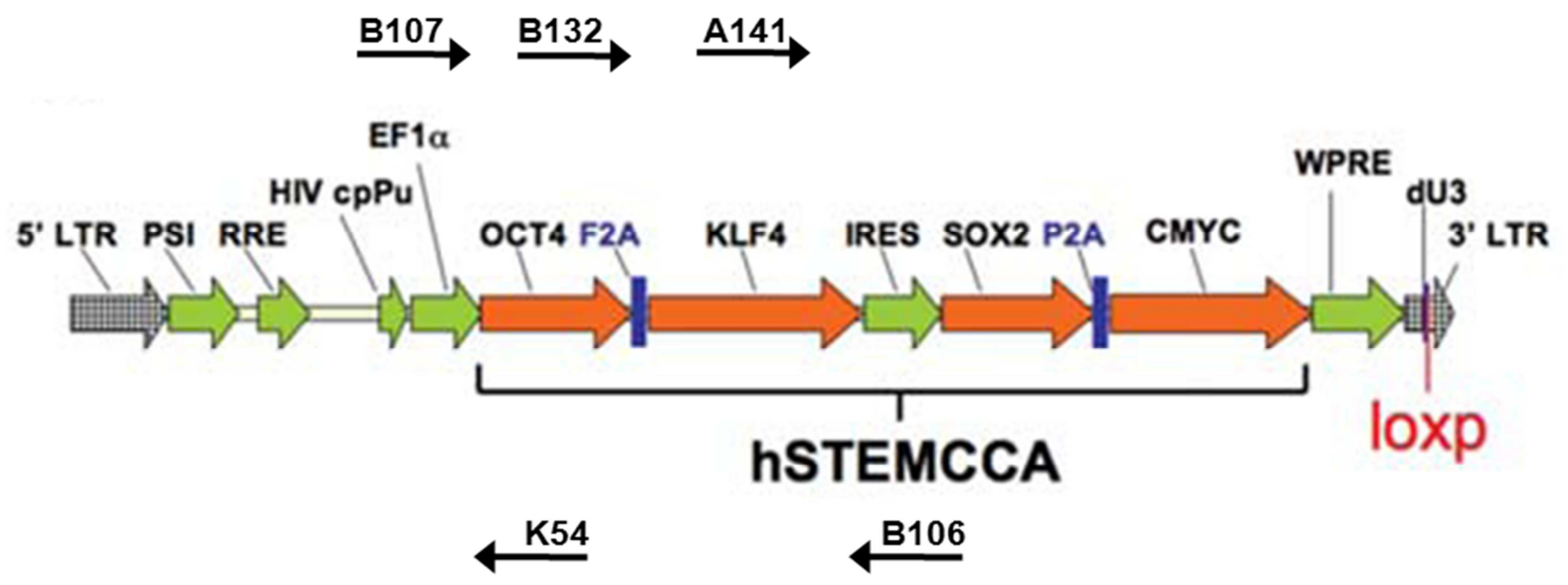

Abb. 5: Das humanisierte lentivirale STEMCCA-System.

Gezeigt sind die Annealing-Stellen der Integrations-Marker. Modifiziert aus Somers et al. 2010, Seite $1728-1740$. 
Hierdurch wurden die vier enthaltenen, spezifischen Pluripotenzgene OCT4, KLF4, SOX2 und $c-M Y C$ in den Fibroblasten überexprimiert.

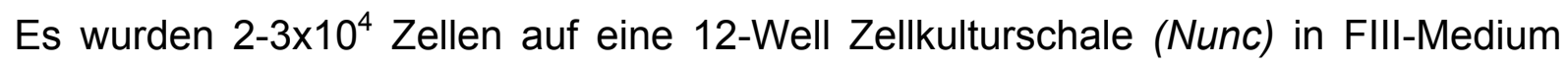
ausplattiert. Am folgenden Tag wurde die Transduktion durchgeführt. Hierfür wurde eine $\mathrm{MOI}$ von 1 verwendet. $\mathrm{MOI}$ bedeutet Multiplizität der Infektion und gibt das zahlenmäßige Verhältnis von Viruspartikeln gegenüber der Zielzelle an. Ein Well der 12-Well-Schale enthielt $700 \mu \mathrm{l}$ FIII-Medium, hinzugefügt wurde die benötigte Menge Virus, $5 \mu \mathrm{l} / \mathrm{ml}$ Polybrene und einfache Penicillin/Streptomycin-Lösung. Anschließend erfolgte eine 24-stündige Inkubation bei $37^{\circ} \mathrm{C}$. Die Entfernung des Virus erfolgte durch zweimaliges Waschen mit DPBS und die Zellen wurden weiterhin mit FIIIMedium kultiviert, wobei täglich ein Mediumwechsel erfolgte. Nach 6-7 Tagen konnten die Zellen auf MEF-beschichtete $6 \mathrm{~cm}$ Zellkulturschalen (Cyto One) überführt und dort mittels $0,1 \%$ T/E passagiert werden. Hierbei wurde das Medium schrittweise auf mES-Medium umgestellt. Schließlich konnten einzelne reprogrammierte Kolonien gepickt, vermehrt und als Zelllinien analysiert werden. Die Zellen wurden von Dr. A. Becker zur Verfügung gestellt.

\subsubsection{Kokultivierung der undifferenzierten murinen ES und iPS mit MEFs}

Die mES bzw. miPS wurden im undifferenzierten Zustand auf mitotisch inaktivierten MEFs in mES-Medium bei $37^{\circ} \mathrm{C}$ kultiviert. Die Zellen wurden alle 24-48 Stunden je nach Koloniedichte passagiert. Hierfür wurden die Zellen mit DPBS gewaschen und dann ca. 5 min bei RT mit 0,1\% T/E inkubiert. Die abgelösten Zellen wurden dann mit DMEM in ein $15 \mathrm{ml}$ Falcon Röhrchen übertragen, bei $445 \mathrm{~g} 5 \mathrm{~min}$ zentrifugiert und schließlich mit mES-Medium auf MEF-beschichtete $6 \mathrm{~cm} \varnothing$ Zellkulturschalen übertragen. Je nach gewünschter Dichte wurden die Zellen im Verhältnis 1:1 bis 1:6 umgesetzt.

Zur Lagerung der Zellen wurden die Zellen in flüssigem Stickstoff eingefroren. Hierfür wurde das Zellpellet nach Verdau mittels $0,1 \%$ T/E und Zentrifugation in $1000 \mu \mathrm{l}$ Einfrier-Medium resuspendiert und in ein 2-ml-Kryoröhrchen (Starlab) übertragen. Diese wurden für die ersten 24 Stunden in einem NalgeneTM Cryo $1^{\circ} \mathrm{C}$ Freezing Container bei $-80^{\circ} \mathrm{C}$ eingefroren, dann in eine Gefrierbox umgelagert und bei längerer Lagerung in flüssigen Stickstoff überführt. 
Für das Auftauen der Zellen wurden diese in einem $37^{\circ} \mathrm{C}$ Wasserbad erwärmt und in ein mit $10 \mathrm{ml}$ kaltem DMEM gefülltes 15-ml-Falcon-Röhrchen übertragen. Nachdem die Zellen bei $445 g$ für 5 min zentrifugiert wurden, erfolgte die Resuspension des Pellets mit mES-Medium und das Ausplattieren auf eine MEF-beschichtete $6 \mathrm{~cm} \varnothing$ Zellkulturschale (Cyto One).

\subsection{In-vitro-Differenzierung von mES und miPS}

Die In-vitro-Differenzierung der murinen iPS-Linien IMOI1 und VMOI1 sowie der murinen ES-Linie ES-7 und der damit verbundene Pluripotenznachweis wurde mittels hanging drop-Methode durchgeführt. Hierfür wurden die auf MEFs kultivierten Zellen mittels preplating von den Fibroblasten getrennt. Die Zellen wurden einmal mit DPBS gewaschen und dann für ca. 5 min bei RT mit 0,1\% T/E inkubiert. Hiernach wurden die abgelösten Zellen mit DMEM Basalmedium in ein $15 \mathrm{ml}$ Falcon Röhrchen übertragen und bei $445 \mathrm{~g} 5$ min zentrifugiert. Die Zellen wurden dann in ES-Medium resuspendiert und auf einer mit $0,1 \%$ Gelatine beschichteten $10 \mathrm{~cm} \varnothing$ Zellkulturschale für 1 Stunde bei $37^{\circ} \mathrm{C}$ ausplattiert. Da die miPS und mES eine geringere Adhärenz als die MEFs aufweisen, ließen sich so die unterschiedlichen Zellpopulationen von einander trennen. Die miPS und mES wurden nach der Trennung zentrifugiert und in Iscove-Medium resuspendiert und mittels Thoma neu Zählkammern gezählt. Es wurden schließlich 140-160 Tropfen á $20 \mu \mathrm{l}$ mit je 300 Zellen mittels Multikanalpipette auf den Deckel einer Bakterienkulturschale (Greiner) pipettiert. Um die Tropfen vor einem Austrocknen zu schützen, wurde vorher der Boden der Bakterienkulturschale mit DPBS gefüllt und schließlich der Deckel in einer fließenden Bewegung vorsichtig aufgelegt. Die hanging drop-Schalen wurden bei $37^{\circ} \mathrm{C}$ für 5 Tage inkubiert. In den 5 Tagen bildeten sich sog. embryoid bodies (EBs).

An Tag 5 wurden die EBs mit Iscove-Medium abgespült und auf mit 0,1\% Gelatine beschichte $10 \mathrm{~cm} \varnothing$ Zellkulturschalen übertragen. Hierbei wurden die EBs von 3 hanging drop Schalen auf eine Zellkulturschale transferiert. Die Zellen wurden bei $37^{\circ} \mathrm{C}$ inkubiert, und es erfolgte alle 48-72 Stunden ein Mediumwechsel. Ab dem Zeitpunkt des Ausplattierens der EBs wurde die Zählweise der Tage mit „5+...“ bezeichnet. 


\subsubsection{Selektion der Kardiomyozyten}

Die Selektion der aus miPS und mES differenzierten Kardiomyozyten wurde an Tag $5+6$ begonnen (Abb. 6).

Hierfür wurde dem zur Differenzierung dienenden Iscove-Medium das Antibiotikum Geneticin (G418) in der Konzentration $800 \mu \mathrm{g} / \mathrm{ml}$ beigefügt. Somit konnte bereits in der folgenden viertägigen Inkubation bei $37^{\circ} \mathrm{C}$ ein Großteil der G418-resistenten Kardiomyozyten selektiert werden.

Um die Kardiomyozyten von den übrigen Zellpopulationen zu trennen, erfolgte an Tag 5+10 ein Verdau. Hierfür wurden die Zellen einmal mit DPBS gewaschen und anschließend für $40 \mathrm{~min}$ bei $37^{\circ} \mathrm{C}$ mit Kollagenase IV verdaut (200 U/ml). Daraufhin wurden die Zellen in ein 50-ml-Falcon-Röhrchen übertragen und bei $445 \mathrm{~g} 5 \mathrm{~min}$ zentrifugiert, mit $0,1 \%$ T/E resuspendiert und erneut für $10 \mathrm{~min}$ bei RT inkubiert. Schließlich nach erneuter Zentrifugation wurde das Pellet mit Iscove-Medium resuspendiert und auf eine mit MEFs beschichtete 3-cm- $\varnothing$-Zellkulturschale ausplattiert. Hierbei dienten die MEFs einem verbesserten Anheften der Kardiomyozyten.

An Tag 5+12 begann eine erneute Selektion mit G418, um die Kardiomyozyten von weiteren Zellresten und den MEFs zu trennen. Zu diesem Zeitpunkt enthielt das verwendete Iscove-Medium eine G418-Konzentration von $400 \mu \mathrm{g} / \mathrm{ml}$. Unter dieser Selektion wurden die Zellen bis Tag $5+17$ bei $37^{\circ} \mathrm{C}$ inkubiert. Die zu diesem Zeitpunkt 22 Tage alten Kardiomyozyten standen nun für weitere Analysen wie PCR, fluorescence associated cell sorting (FACS) und In-vitro-Färbung zur Verfügung. 


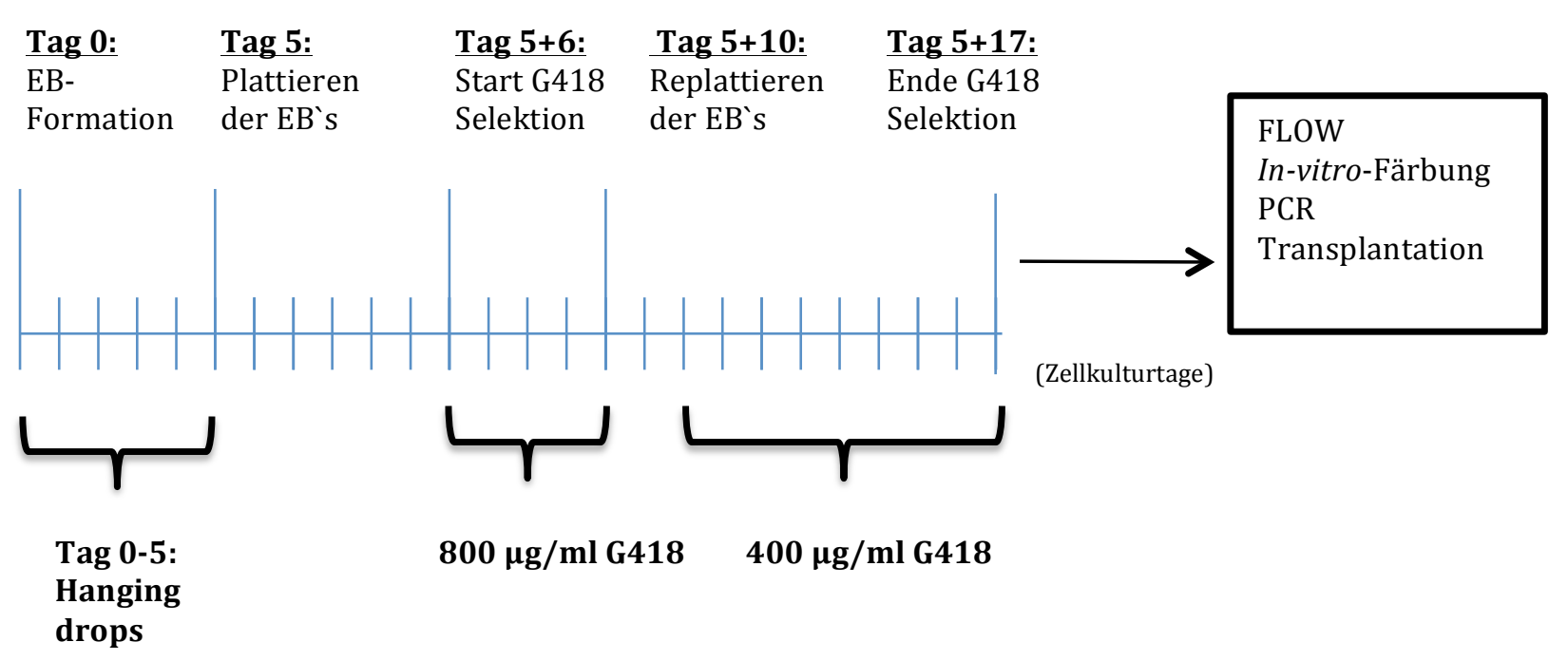

Abb. 6: Protokoll der kardialen Differenzierung und Selektion

\subsection{Analyse der expandierenden undifferenzierten pluripotenten Zellen}

\subsubsection{Zellzählung}

Zur Analyse der Zellproliferation wurden jeweils 50.000 Zellen der Zelllinien IMOI1, VMOI1 und ES-7 zu drei Zeitpunkten untersucht. Die Zellen wurden wie folgt vorbereitet: Nach Kultivierung auf MEF beschichteten $6 \mathrm{~cm} \varnothing$ Zellkulturschalen wurden die Zellen mittels DPBS gewaschen, durch 0,1\% T/E verdaut und in $15 \mathrm{ml}$ Falcon Röhrchen 5 min bei $445 \mathrm{~g}$ zentrifugiert. Hiernach wurden die Zellen in mESMedium resuspendiert und zur Trennung der MEFs auf mit Gelatine beschichtete Zellkulturschalen $(10 \mathrm{~cm} \varnothing)$ ausplattiert (preplating). Das preplating erfolgte für 60 min bei $37^{\circ} \mathrm{C}$. Hiernach wurde der Überstand in ein $15 \mathrm{ml}$ Falcon Röhrchen überführt und erneut $5 \mathrm{~min}$ bei $445 \mathrm{~g}$ zentrifugiert. Die Zellen wurden mittels DPBS resuspendiert und unter Verwendung von Thoma neu Zählkammern gezählt. Es wurden pro Zelllinie 9 mit Gelatine beschichtete Zellkulturschalen $(6 \mathrm{~cm} \varnothing)$ mit je 50.000 Zellen ausplattiert. Somit konnten nach Tag 1, Tag 2 und Tag 3 jeweils $n=3$ Schalen jeder Zelllinie mittels Thoma neu Zählkammern analysiert werden.

Die Wachstumsrate (Verdopplungszeit) der Zellen wurde aus der halblogarithmischen (In) Darstellung der Wachstumskurven errechnet. 


\subsubsection{Karyotypisierung}

Die Zelllinien IMOI1, VMOI1 und ES-7 wurden für die Karyotypisierung höher passagiert (mind. p20) verwendet. Um die Qualität und Quantität der MetaphaseChromosomen untersuchen zu können, wurden von jeder Zelllinie jeweils eine gut gefüllte 6 -cm- $\varnothing$-Zellkulturschale 1:3 auf $3 \times 6-\mathrm{cm}-\varnothing$-Zellkulturschalen umgesetzt. Nach zwei Tagen befanden sich die Zellen in ausgeprägter Proliferation, so dass zum Blocken des Zellzyklus in der Metaphase Demecolcin $(0,1 \mu \mathrm{g} / \mathrm{ml})$ zum Medium hinzugefügt werden konnte. Hiermit wurden die Zellen für 16 Stunden bei $37^{\circ} \mathrm{C}$ inkubiert. Nach der Inkubation wurde der Überstand in ein 15-ml-Falcon-Röhrchen überführt und die Zellen mit DPBS gewaschen. Des Weiteren wurden die Zellen für 5 min bei $37^{\circ} \mathrm{C}$ mit $0,1 \% \mathrm{~T} / \mathrm{E}$ inkubiert. Nach dem Verdau wurde ein Teil des vorher gesammelten Überstandes genutzt, um die Zellen in ein $15 \mathrm{ml}$ Falcon Röhrchen zu übertragen. Die Zellen wurden für 6 min bei $200 \mathrm{~g}$ zentrifugiert. Hiernach wurden die Zellen mit einem weiteren Rest des Überstandes resuspendiert, und es wurde tröpfchenweise $1 \mathrm{ml}$ vorgewärmte, hypotone 0,4\% Kaliumchlorid ( $\mathrm{KCl}$ )- und 0,4\% Natriumzitrat-Lösung hinzugefügt. Nachdem die Zell-Suspension auf $2 \mathrm{ml}$ aufgefüllt worden war, erfolgte eine $7 \mathrm{~min}$ Inkubation bei $37^{\circ} \mathrm{C}$. Es folgte eine erneute Zentrifugation, woraufhin das Pellet wiederholt mit einer geringen Menge des übertragenen Überstandes resuspendiert wurde. Zur Fixierung wurde $1 \mathrm{ml}$ MethanolEisessig in einem Verhältnis 3:1 tröpfchenweise hinzugefügt. Nachdem die Zellsuspension auf $2 \mathrm{ml}$ aufgefüllt worden war, erfolgte eine 30-minütige Inkubation bei RT. Die Zellen wurden zentrifugiert und mit $2 \mathrm{ml}$ des Fixativs erneut vorsichtig resuspendiert. Es erfolgte eine weitere Inkubation für $20 \mathrm{~min}$ bei RT. Nach wiederholtem Zentrifugieren wurden die Zellen mit einer kleinen Menge des Fixativs resuspendiert und auf $4^{\circ} \mathrm{C}$ vorgekühlte und in destilliertem Wasser gelagerte sowie mit Fixativ abgespülte Objektträger getropft.

Nachdem die Objektträger getrocknet waren, wurden sie mit einer modifizierten Giemsa-Färbung für 5 min gefärbt und daraufhin $3 x$ mit destilliertem Wasser gewaschen. Die Objektträger konnten nun unter Verwendung eines Zeiss Axio Imager.M2 Mikroskops in Kombination mit Applied Spectral Imaging Software (Case Data Manager 6.0) analysiert werden. 


\subsubsection{Alkalische Phosphatase-Färbung}

Zum Nachweis der Pluripotenz der iPS-Linien IMOI1, VMOI1 und der ES-Linie ES-7 wurde die alkalische Phosphataseaktivität der Zellen überprüft. Hierfür wurde das Mouse Kit $86 \mathrm{C}$ von Sigma verwendet. In Vorbereitung der Färbung wurden $300 \mu \mathrm{l}$ Natriumnitrat 1:1 mit $300 \mu$ FBB-alkalischer Lösung gemischt und für 2 min bei RT inkubiert. Hiernach wurde das Gemisch in $13,5 \mathrm{ml} \mathrm{H}_{2} \mathrm{O}$ pipettiert und unmittelbar vor der Verwendung $300 \mu \mathrm{l}$ Naphtol AS-B hinzugefügt.

Für die Analyse mittels alkalischer Phosphatase-Färbung wurden zu 75\% gefüllte 6 $\mathrm{cm} \varnothing$ Zellkulturschalen verwendet. Das Medium wurde abgesaugt und die Zellen 1x mit DPBS gewaschen. Hiernach wurden die Zellen für $30 \mathrm{~s}$ mit folgender Fixierlösung fixiert: $5 \mathrm{ml}$ Zitrat-Lösung $+13 \mathrm{ml}$ Azeton $+1,6 \mathrm{ml}$ Formaldehyd $(37 \%)$, die bei $2-8^{\circ} \mathrm{C}$ in einer gekühlten Glasflasche angesetzt und zum Gebrauch auf $18-26^{\circ} \mathrm{C}$ erwärmt wurde.

Nach der Fixierung wurden die Zellen für eine Minute mit destilliertem Wasser gewaschen und danach für $15 \mathrm{~min}$ bei RT mit der oben genannten Färbelösung inkubiert. Darauffolgend wurden die Zellen für zwei Minuten mit $\mathrm{H}_{2} \mathrm{O}$ gewaschen und für $10 \mathrm{~s}$ mit Neutral-Rot gegengefärbt. Zum Abschluss wurden die Zellen mehrfach mit Leitungswasser gewaschen und schließlich trocknen gelassen.

\subsection{Isolation von DNA und Methylierungs-Analyse}

Zur Analyse der Zellen auf epigenetischer Ebene wurde aus bei $-80^{\circ} \mathrm{C}$ gelagerten Zellpellets mit dem Quiagen DNA-Mini-Kit inklusive einer Ribonuklease (RNAse) Inkubation DNA isoliert. Hierzu wurde das Zellpellet in $200 \mu$ DPBS resuspendiert. Es wurden $20 \mu \mathrm{l}$ Proteinase $\mathrm{K}$ sowie $4 \mu \mathrm{l}$ RNAse-Lösung $(100 \mathrm{mg} / \mathrm{ml})$ hinzugefügt. Im folgenden wurden $200 \mu \mathrm{l}$ AL-Puffer (Lysierungspuffer) hinzupipettiert und das Gemisch für $15 \mathrm{~s}$ gevortext. Es folgte eine Inkubation von $10 \mathrm{~min}$ bei $56^{\circ} \mathrm{C}$ in einem Heizblock. Nach einer kurzen Zentrifugation wurden $200 \mu$ l reines Ethanol hinzugegeben und das Gemisch für $15 \mathrm{~s}$ gevortext sowie erneut zentrifugiert. Der gesamte Mix wurde nun auf eine von Qiagen bereitgestellte Säule in einem Collection Tube gegeben und bei geschlossenem Deckel für eine Minute bei $8.000 \mathrm{~g}$ zentrifugiert. Anschließend wurde die Säule auf ein frisches $2 \mathrm{ml}$ Tube gesteckt und das Tube mit dem Filtrat verworfen. Jetzt wurden der Säule $500 \mu \mathrm{l}$ AW1-Puffer 
hinzugefügt und $1 \mathrm{~min}$ bei $8.000 \mathrm{~g}$ zentrifugiert. Daraufhin wurde die Säule in ein weiteres unbenutztes Sammeltube überführt und $500 \mu \mathrm{l}$ AW2-Puffer hinzupipettiert. Es folgte eine Zentrifugation von $3 \mathrm{~min}$ bei $14.000 \mathrm{~g}$. Die Säule wurde nun wiederholt auf ein neues Sammeltube gesteckt, und sie wurde nochmals für $1 \mathrm{~min}$ bei $13.000 \mathrm{~g}$ zentrifugiert. Nun erfolgte die Elution. Hierzu wurde die Säule auf ein frisches 1,5 mlEppendorf Tube platziert, und es wurden $55 \mu \mathrm{l}$ Nuklease-freies Wasser hinzugefügt. Es folgte eine 5-minütige Inkubation bei RT und abschließend eine 1-minütige Zentrifugation bei $8.000 \mathrm{~g}$. Die DNA-Konzentration wurde bei $260 \mathrm{~nm} / 280 \mathrm{~nm}$ mit einem Spektrophotometer gemessen und die eluierten Proben bei $-80^{\circ} \mathrm{C}$ gelagert.

Die Methylierungsschemata des Promotors von Oct4 der analysierten iPS-Linien wurde von der Firma Epigenomics AG untersucht. Hierfür wurde jeweils eine DNAProbe der miPS IMOI1 und VMOI1 sowie der jeweiligen Ursprungszellen la* und V1* (MEFs der Mäuse I und V) mit Natriumbisulfit behandelt. Es wurden spezifische Bereiche des Pluripotenzgens analysiert, wobei die Lage der jeweiligen Bereiche zum Abstand des Startcodons angegeben wurde.

Oct4-Gen (NM_013633.2):

Abschnitt $-0,7 \mathrm{~kb}$ bis $+0,1 \mathrm{~kb}$ im Minimalpromotor (MP) des Gesamttransskripts ENSMUST00000025271 beinhaltet das Startcodon des Oct4-Gens. Primer: 5'-TAA GAA TTG AGG AGT GGT TTT-3', 5'-AAA TCT AAA ACC AAA TAT CCA AC-3'

\subsection{0 mRNA-Expressions-Analysen der undifferenzierten, ungerichtet differenzierten Zellen und Kardiomyozyten}

\subsubsection{Isolation von RNA}

Die Isolation von RNA wurde mit dem SV Total RNA Isolation System (Promega) durchgeführt. Zur Lysierung der Zellen wurde RNA-Lysierungspuffer verwendet, der mit $\beta$-ME $(200 \mu \mathrm{l} / 10 \mathrm{ml})$ versetzt wurde. Das Zelllysat wurde mit $95 \%$ Ethanol in einem Verhältnis von 1:1 gemischt und in ein Spin Basket Assembly des Promega kits übertragen. Nach $1 \mathrm{~min}$ Zentrifugation bei $12.000 \mathrm{~g}$ und RT wurden die Proben mit $600 \mu \mathrm{l}$ RNA-Waschlösung gereinigt und erneut zentrifugiert. Darauffolgend wurden $50 \mu \mathrm{l}$ DNAse Mix $(40 \mu \mathrm{l}$ Yellow Core Puffer, $5 \mu \mathrm{l}$ 0,09 M Mangandichlorid $\left(\mathrm{MnCl}_{2}\right), 5 \mu \mathrm{LNAse} \mathrm{I}$ ) auf die Membran des Spin Baskets pipettiert und für $15 \mathrm{~min}$ 
bei RT inkubiert. Hiernach wurden $200 \mu$ LNAse-Stop-Lösung auf die Membran gegeben und erneut zentrifugiert, einmal mit $600 \mu \mathrm{l}$ RNA-Waschlösung und einmal mit $250 \mu \mathrm{l}$ RNA-Waschlösung gereinigt und jeweils danach erneut zentrifugiert. Die Proben wurden nun 2 min bei $12.000 \mathrm{~g}$ und RT zentrifugiert. Schließlich wurde die RNA in 100-200 $\mu$ l Nuklease-freiem Wasser durch erneute Zentrifugation bei $1 \mathrm{~min}$, $12.000 \mathrm{~g}$ und RT eluiert. Die RNA-Konzentration wurde bei $260 \mathrm{~nm} / 280 \mathrm{~nm}$ mit einem Spektrophotometer gemessen und die eluierten Proben bei $-80^{\circ} \mathrm{C}$ gelagert.

\subsubsection{Reverse Transkription}

Zum Nachweis von Pluripontenz- und Differenzierungsmarkern wurden $200 \mathrm{ng}$ der isolierten RNA in komplementäre cDNA transkribiert. Tabelle 4 zeigt die Komponenten von $20 \mu \mathrm{l}$ Reverser Transkriptase-Lösung. Außer der dNTPs von Bioline wurden alle Zusätze von Applied Biosystems bezogen. Tabelle 5 zeigt den Programm-Ablauf.

Tab. 4: Komponenten einer $20 \mu \mathrm{I}$ RT-PCR-Reaktion

\begin{tabular}{ll}
\hline Komponenten & Gesamtvolumen $\mathbf{2 0} \boldsymbol{\mu l}$ \\
\hline $200 \mathrm{ng}$ RNA + DEPC Wasser & $10,2 \mu \mathrm{l}$ \\
10 x PCR Puffer II & $2 \mu \mathrm{l}$ \\
$25 \mathrm{mM} \mathrm{MgCl} 2$ & $4 \mu \mathrm{l}$ \\
$100 \mathrm{mM}$ dNTP & $0,8 \mu \mathrm{l}$ \\
RNAse Inhibitor $(20 \mathrm{U} / \mu \mathrm{l})$ & $1 \mu \mathrm{l}$ \\
Oligo $(\mathrm{dT})_{16}(50 \mu \mathrm{M})$ & $1 \mu \mathrm{l}$ \\
MuLV reverse Transkriptase $(50 \mathrm{U} / \mu \mathrm{l})$ & $1 \mu \mathrm{l}$ \\
\hline
\end{tabular}

Tab. 5: Programm für cDNA-Synthese

\begin{tabular}{|l|l|l|l|l|}
\hline & Schritt 1 & Schritt 2 & Schritt 3 & Schritt 4 \\
\hline Temperatur & $22^{\circ} \mathrm{C}$ & $42^{\circ} \mathrm{C}$ & $95^{\circ} \mathrm{C}$ & $4^{\circ} \mathrm{C}$ \\
\hline Zeit & $10 \mathrm{~min}$ & $50 \mathrm{~min}$ & $10 \mathrm{~min}$ & $\infty$ \\
\hline
\end{tabular}




\subsubsection{Polymerasekettenreaktion (PCR)}

Der Nachweis von Puripotenz- und kardialen Markern wurde u. a. mittels PCR durchgeführt. Hierfür wurden $2 \mu \mathrm{l}$ cDNA zum PCR Master Mix hinzu gegeben, so dass ein Gesamtvolumen von $50 \mu \mathrm{l}$ entstand (Tab. 6).

Tab. 6: Komponenten eines PCR Master Mix (48 $\mu$ l)

\begin{tabular}{ll}
\hline Komponenten & Gesamtvoumen $48 \boldsymbol{\mu l}$ \\
\hline $200 \mathrm{ng}$ cDNA + DEPC Wasser & $30,6 \mu \mathrm{l}$ \\
5 x GoTaq Puffer I & $10,0 \mu \mathrm{l}$ \\
$10 \mathrm{mM}$ dNTP & $3,2 \mu \mathrm{l}$ \\
sense Primer $(10 \mathrm{pmol} / \mu \mathrm{l})$ & $2,0 \mu \mathrm{l}$ \\
antisense Primer $(10 \mathrm{pmol} / \mu \mathrm{l})$ & $2,0 \mu \mathrm{l}$ \\
GoTaq Polymerase $(5 \mathrm{U} / \mu \mathrm{l})$ & $0,2 \mu \mathrm{l}$ \\
\hline
\end{tabular}

Die PCR-Reaktionen wurden mit einem SensoQuest Termocycler durchgeführt. Die verwendeten Programme finden sich in Tab. 7.

Tab. 7: Programm für PCR

\begin{tabular}{|l|l|l|}
\hline Amplifikation & Temperatur & Zeit \\
\hline Initiale Denaturation & $95^{\circ} \mathrm{C}$ & $3 \mathrm{~min}$ \\
\hline Denaturation & $95^{\circ} \mathrm{C}$ & $15 \mathrm{~s}$ \\
\hline Annealing & $52-65^{\circ} \mathrm{C}$ & $15 \mathrm{~s}$ \\
\hline Elongation I & $72^{\circ} \mathrm{C}$ & $30 \mathrm{~s}$ \\
\hline Elongation II & $72^{\circ} \mathrm{C}$ & $10 \mathrm{~min}$ \\
\hline Finale Temperatur & $4^{\circ} \mathrm{C}$ & $\infty$ \\
\hline
\end{tabular}

Die exakten Annealing Temperaturen und Zyklenzahlen finden sich für die verwendeten Primer in Tab. 1. 


\subsubsection{Gelelektrophorese}

Zur Analyse der mittels PCR erstellten Proben wurde eine Gelelektrophorese mit anschließender Betrachtung des Gels unter UV-Licht durchgeführt. Hierfür wurde ein 1\%-iges Agar-Gel erstellt. In $200 \mathrm{ml}$ 1x TB-Puffer wurden $2 \mathrm{~g}$ DNA-Agar durch Erhitzen in einer Mikrowelle gelöst. Daraufhin wurde Ethidiumbromid in der Konzentration $6 \mu \mathrm{l}$ pro $100 \mathrm{ml}$ hinzugefügt und gemischt. Nach dreißigminütigem Aushärten des Gels konnte es für die Elektrophorese verwendet werden.

Die PCR-Produkte wurden bei $120 \mathrm{~V}$ für ca. 60 min separiert und ihre Länge mittels GeneRuler $^{\text {tm }} 100$ bp Plus DNA Ladder (Fermentas) analysiert.

\subsection{Immunfluoreszenz-Analyse der undifferenzierten Zellen und Kardiomyozyten}

Bei der Immunfluoreszenz-Analyse wurden die iPS-Linien IMOI1 und VMOI1 sowie die ES-Linie ES-7 auf Pluripotenz- und Differenzierungsmarker auf Proteinebene untersucht. Hierbei wurden die pluripotenten Zellen auf mit MEFs beschichtete Deckgläschen plattiert.

Um die Kardiomyozyten im differenzierten Zustand analysieren zu können, wurden schlagende, mit G418 selektierte Kardiomyozyten (Tag 5+10) mit DPBS gewaschen und $40 \mathrm{~min}$ bei $37^{\circ} \mathrm{C}$ mit Kollagenase IV verdaut, bei $445 \mathrm{~g} 5 \mathrm{~min}$ zentrifugiert, mit T/E resuspendiert und erneut für $10 \mathrm{~min}$ bei RT inkubiert und schließlich mit Differenzierungsmedium auf mit MEFs beschichtete chamber slides übertragen. Auf den chamber slides wurden die Zellen bis zur Fixierung an Tag 5+17 mit Differenzierungsmedium (Wechsel alle 2 Tage) kultiviert, wobei ab Tag 5+12 erneut mit halber Konzentration G418 selektiert wurde.

Die Zellen wurden mit 4\% PFA 20 min bei RT fixiert. Hiernach wurden die Zellen 3x mit DPBS gewaschen und mit $1 \%$ BSA 12 Stunden bei $4^{\circ} \mathrm{C}$ geblockt. Für die Analyse im Kern lokalisierter Marker wurden die Zellen mit 0,1\% Triton-X-100 für 20 min bei RT inkubiert. Im Folgenden wurden die Zellen erneut $3 x$ mit DPBS gewaschen und in einer feuchten Kammer für 1 Stunde bei $37^{\circ} \mathrm{C}$ mit dem primären Antikörper inkubiert. Nach der Inkubation wurden die Zellen wieder mit DPBS gewaschen und mit dem sekundären Antikörper bei $37^{\circ} \mathrm{C}$ für 1 Stunde inkubiert. Anschließend erfolgte erneut 3x Waschen und eine 10-min-Inkubation bei RT mit DAPI (1:5.000). 


\subsection{Quantitative Analyse der Kardiomyozyten}

Die Durchflusszytometrie wurde durchgeführt, um einen quantitativen Nachweis der eGfp-positiven Kardiomyozyten zu erhalten. Zur Analyse der Zellen wurden diese mittels preplating von ihren MEFs getrennt und vereinzelt, jedoch nicht G418selektiert. Die Zellen wurden in ein $15 \mathrm{ml}$ Falcon Röhrchen übertragen und $3 \mathrm{x}$ hintereinander mit DPBS gewaschen und bei $445 \mathrm{~g} 5 \mathrm{~min}$ zentrifugiert. Dann wurden die Zellen mit $400 \mu$ l 0,5\% BSA resuspendiert und über ein $70 \mu \mathrm{m}$ Zellfilter von $B D$ Bioscience in ein Röhrchen für Durchflusszytometrie von Becton-Dickinson pipettiert. Zur Messung diente ein FACS Canto von Becton-Dickinson und die Sofware FACSDIVA.

Da die Durchflusszytometrie ausschließlich den eGfp-positiven Kardiomyozytenanteil ohne eine Antibiotikaselektion ermittelte, wurde der eGfp-positive Kardiomyozytenanteil zusätzlich nach Antibiotikaselektion bestimmt. Dies erfolgte anhand der in 2.11 beschriebenen DAPI- bzw. a-Aktinin-Färbung der differenzierten Kardiomyozyten. Hierfür wurden unter einem Fluoreszenzmikroskop die sowohl DAPI- als auch a-Aktinin-positiven Kardiomyozyten gezählt und mit der Anzahl ausschließlich DAPI-positiver Zellen verglichen (siehe 3.4.2).

\subsection{Statistische Analysen}

Die Ergebnisse sind als arithmetische Mittelwerte $(x) \pm$ Standardabweichung angegeben. Die Daten wurden mit Hilfe des parametrischen ungepaarten Student tTest analysiert. p-Werte $<0,05$ werden als statistisch signifikant betrachtet. 


\section{Ergebnisse}

Die Charakterisierung der miPS-Linien IMOI1 und VMOI1 sowie der mES-Linie ES-7 erfolgte anhand folgender Kriterien: Es wurde die Morphologie, Pluripotenzmarker, DNA-Methylierung, Zellproliferation der Zelllinien und die In-vitro-Differenzierung untersucht sowie der Karyotyp bestimmt (siehe 3.1, 3.2 und 3.3). Die Analyse der kardialen Differenzierung und der kardialen Differenzierungseffizienz wird unter 3.4 beschrieben.

\subsection{Nachweis der Pluripotenz}

Der Nachweis der Pluripotenz erfolgte zunächst bei den Zelllinien IMOI1, VMOI1 und ES-7 mittels ihrer alkalischen Phosphataseaktivität. Die beiden miPS-Linien und die mES-Linie zeigten eine rege Aktivität der alkalischen Phosphatase. Des Weiteren wiesen alle drei Zelllinien eine für miPS bzw. mES typische Morphologie auf, dies bedeutet eine runde bis ovale kompakte Zellkoloniestruktur mit einem lichtmikroskopisch gut erkennbaren hellen Randsaum (Abb. 7).

Des Weiteren wurde die mRNA-Expression der Pluripotenz Marker cell lineage abnormal 28 (Lin28), Rex1, Nanog und Oct4 überprüft. Hierfür wurden Proben der Zellinien IMOI1, VMOI1 und ES-7 (jeweils $n=3$ ) genommen und ihre RNA isoliert. Die verwendeten Proben waren Zellen zwischen Passage 15 und 20.

Die reverse Transkriptions-PCR (RT-PCR)-Analyse zeigte, dass Lin28, Rex1, Nanog und Oct4 nicht nur in der ES-Linie 7 sondern auch in den untersuchten iPS-Linien IMOI1 und VMOI1 exprimiert wurden. Im Gegensatz hierzu zeigten die MEFs la* und V1*, sowie die analysierten MEFs keine Expression der Pluripotenzmarker. Als Positivkontrolle wurde die etablierte mES-Linie MPI-II verwendet, welche eine Expression von Lin28, Rex1, Nanog und Oct4 zeigte.

Mittels der Primer A141 und B106 wurde die mRNA-Expression der Gensequenz KLF4 und internal ribosomal entry site (IRES) und somit die Expression des STEMCCA-Virus überprüft. Die Zellen IMOI1 und VMOI1 wiesen diese Expression auf, ES-7 nicht. KLF4 und IRES wurden ebenfalls nicht in der mES-Linie MPI-II und den MEFs exprimiert (Abb. 8). 

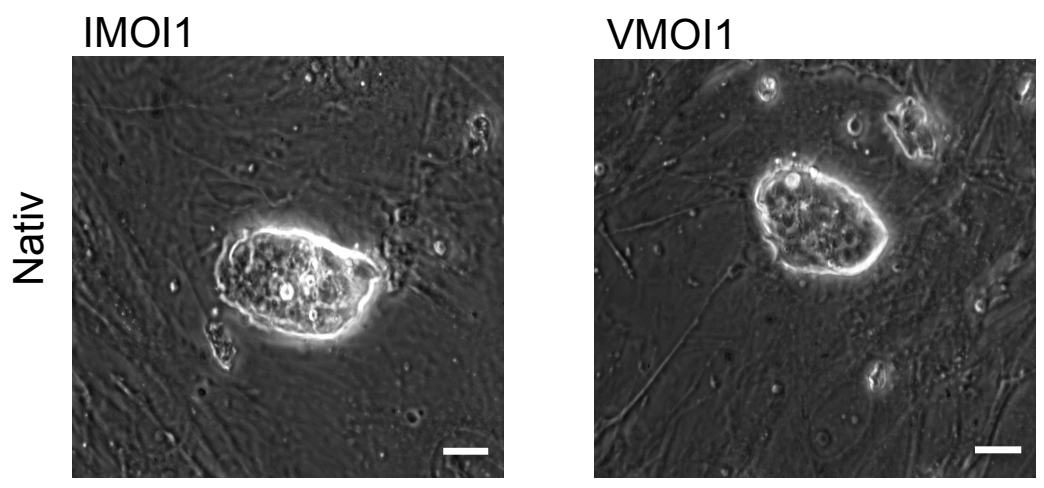

\section{ES-7}
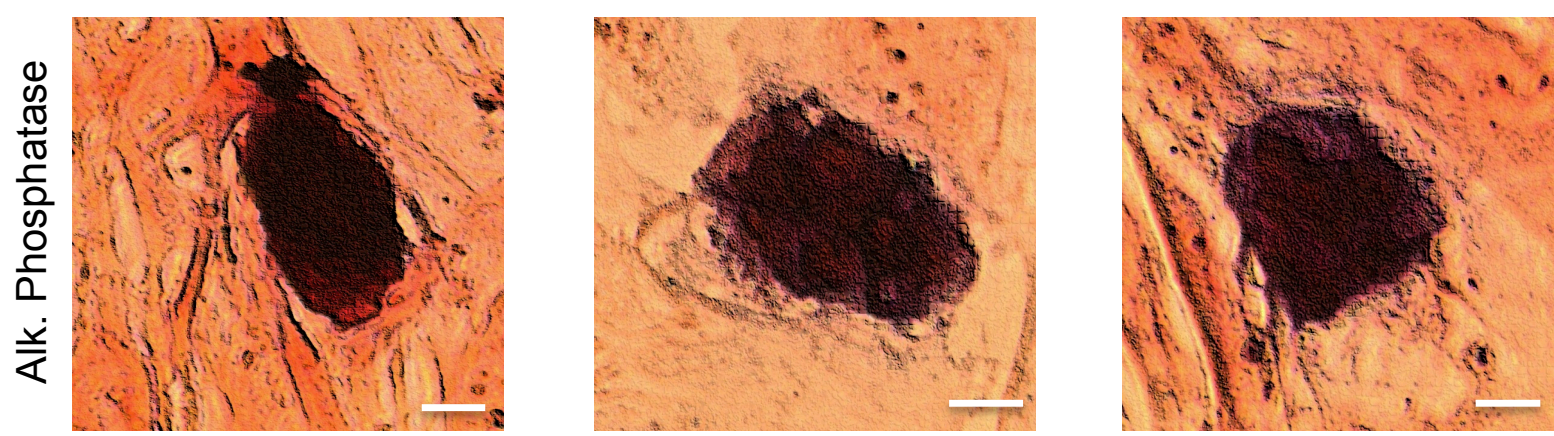

\section{Abb. 7: Morphologie und alkalische Phosphataseaktivität.}

Undifferenzierte murine iPS und ES auf mitotisch inaktivierten MEFs. Die Bilder der oberen Reihe zeigen die Morphologie der analysierten Zellen. Die Zellinien IMOI1, VMOI1 und ES-7 weisen eine typische Morphologie von murinen, pluripotenten Stammzellkolonien auf. Die Abbildungen der unteren Reihe zeigen die Färbung auf alkalische Phosphataseaktivität. Eine Blauviolettfärbung entspricht einer starken alkalischen Phosphataseaktivität, wohingegen rot gefärbte Zellen keine bzw. eine geringe Aktivität aufweisen. Skalierung: $20 \mu \mathrm{m}$. 


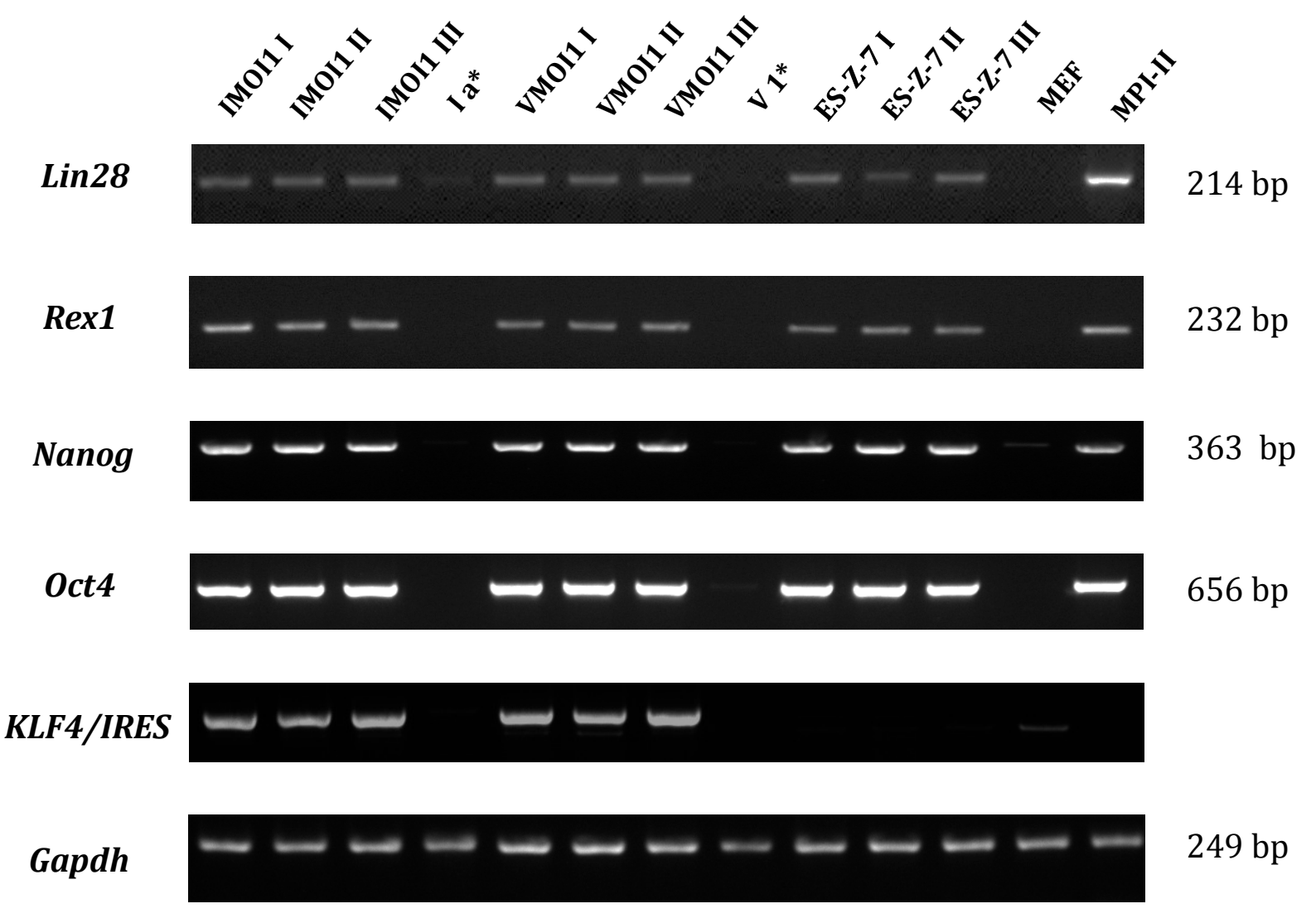

Abb. 8: Genexpressionsanalyse der Zelllinien IMOI1, VMOI1 und ES-7 (jeweils $n=3$ ).

RT-PCR-Analyse der endogenen Expression von Lin28, Rex1, Nanog und Oct4. Die Expression der analysierten Marker der iPS zeigte keine Unterschiede im Vergleich zu den ES. Als Negativkontrolle dienten MEFs. Außerdem wurde anhand der Primer A141/B106 die Expression eines Abschnitts (KLF4 und IRES) des STEMCCA in den iPS-Linien nachgewiesen. Glycerinaldehyd-3-PhosphatDehydrogenase (Gapdh) diente als Referenzgen.

Außerdem wurde die Expression der Stammzellmarker Oct4, Sox2, Nanog und stage-specific embryonic antigen 1 (SSEA-1) auf Proteinebene unter Durchführung von immunzytochemischen Färbungen analysiert (Abb. 9). 

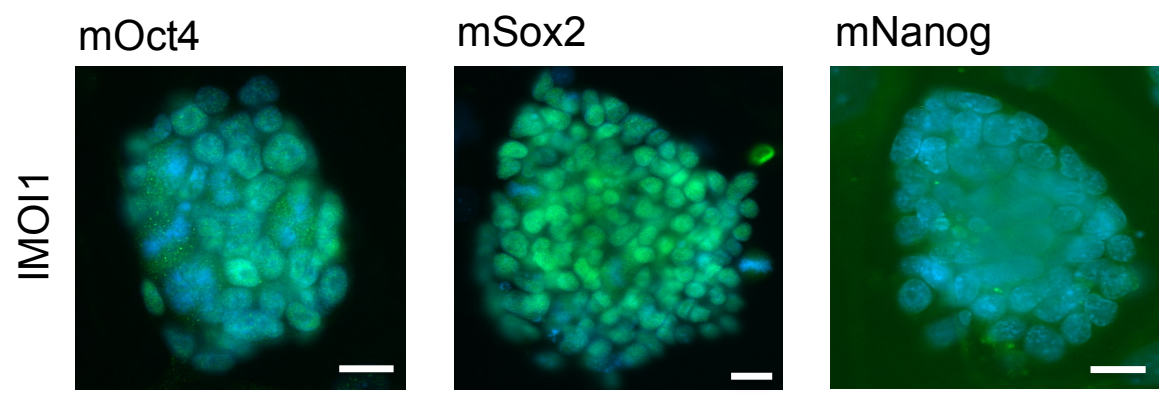

mSSEA-1
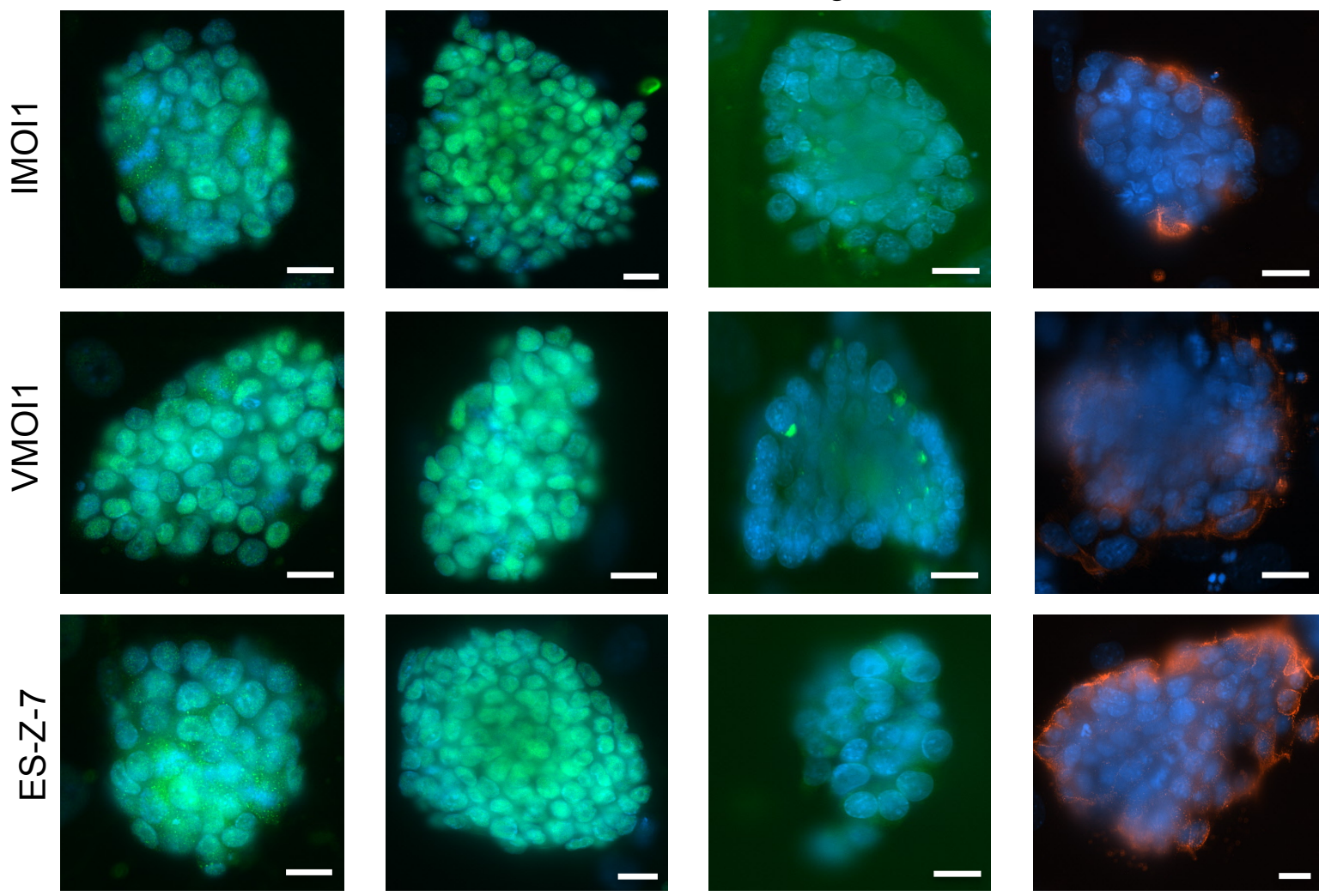

Abb. 9: Immunfluoreszenzfärbungen der Zelllinien IMOI1, VMOI1 und ES-7.

Sowohl die iPS als auch die ES-Linie waren Oct4, Sox2, Nanog und SSEA-1 positiv. Die Zellkerne wurden durch DAPI (blau) gefärbt. Skalierung: $20 \mu \mathrm{m}$.

Die Transkriptionsfaktoren Oct4, Sox2 und Nanog zeigten positive Signale in den Zellkernen der iPS-Linien IMOI1, VMOI1 und der ES-Linie ES-7. Das Signal des Zellmembran-lokalisierten Oberflächenmarkers SSEA-1 war ebenfalls in IMOI1, VMOI1 und ES-7 positiv.

Die iPS-Linien IMOI1 und VMOI1 wurden des Weiteren auf ihr Methylierungsschema durch epigenetische Analysen untersucht (Abb. 10). Bei der DNA-Methylierung werden Methylgruppen durch Methyltransferasen an DNA gebunden. Dies verändert die Funktion der DNA, vor allem um eine Gentranskription zu supprimieren. Die DNA-Methylierung ist essentiell für eine normale Entwicklung und spielt eine wichtige Rolle in Prozessen wie z.B. genomischem Imprinting, Inaktivierung des XChromosoms, Supprimierung repetitiver Sequenzen und Karzinogenese.

Die Analyse erfolgte im Vergleich mit den jeweiligen MEFs, aus denen die iPS im Vorfeld generiert wurden. Es wurden regulatorische Bereiche des Oct4-Gens (Pou5Locus) dargestellt. 
$1 a^{*}$

$\mathrm{V} 1^{*}$

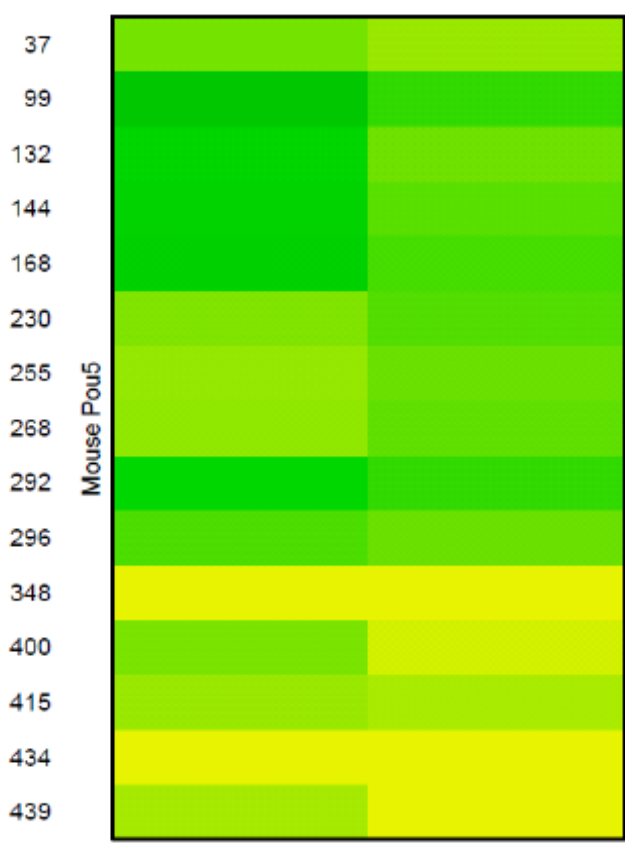

MEF
IMOI1 VMOI1

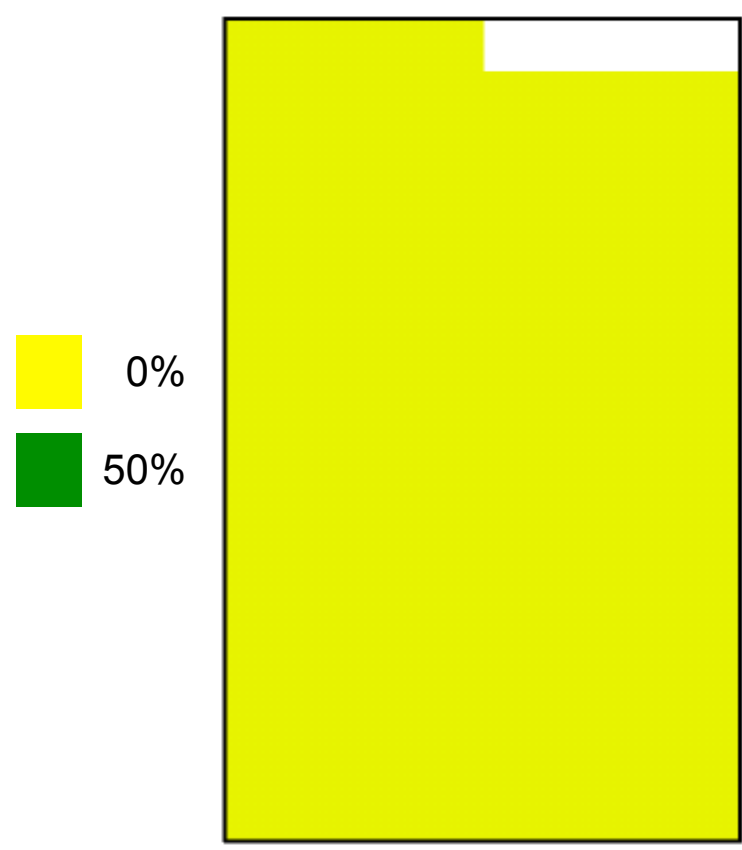

iPS

Abb. 10: Darstellung der Methylierungsgrade der iPS IMOI1 und VMOI1 verglichen mit ihren jeweiligen MEFs.

Die beiden Plots zeigen die Analyse von Maus Pou5 (mPou5/mOct4). Hierbei sind sowohl la* als auch V1* semimethyliert, IMOI1 und VMOI1 liegen demethyliert vor.

Das Differenzierungspotenzial der generierten miPS bzw. mES wurde schließlich durch In-vitro-Differenzierung mittels hanging drop-Methode überprüft.

Die Morphologie der Zellkolonien bzw. EBs der Zelllinien IMOI1, VMOI1 und ES-7 ist in Abb. 11 dargestellt. Hierzu wurden die Zellen an Tag 0, Tag 5+5 und Tag 5+15 dokumentiert. Die zum Zeitpunkt Tag 0 dargestellten Zellen befinden sich unmittelbar vor der EB-Formation noch auf MEFs plattiert. Die an Tag 5+5 bzw. Tag 5+15 gezeigten EBs sind auf 0,1\% Gelatine-Zellkulturschalen plattiert.

Die Zellkolonien erschienen vor Beginn der Differenzierung mittels hanging dropMethode als ovale Zellverbände mit im Lichtmikroskop hell erscheinendem Rand und einem maximalen Durchmesser von ca. $350 \mu \mathrm{m}$. Es konnten keine signifikanten morphologischen Unterschiede zwischen den einzelnen Zelllinien festgestellt 
werden. Die EBs stellten sich an Tag 5+5 als runde bis ovale Strukturen mit homogener Oberfläche dar. Auch zu diesem Zeitpunkt erschienen die EBs der iPS und ES morphologisch gleich aussehend. An Tag 5+15 konnte ein sich um den ursprünglichen EB formierter Zellverband mit heterogener Zelldichte dokumentiert werden. Die Morphologie der EBs der Zelllinien IMOI1, VMOI1 und ES-7 unterschieden sich an Tag 5+15 in der Mehrzahl der Versuche nicht. Es fiel jedoch auf, dass die EBs der iPS-Linie VMOI1 bei einigen Versuchen zu diesem Zeitpunkt eine ähnliche Morphologie wie bereits zum Zeitpunkt Tag 5+5 aufwiesen und ein vermindertes Ausbreiten des peripheren Zellverbandes zeigten.
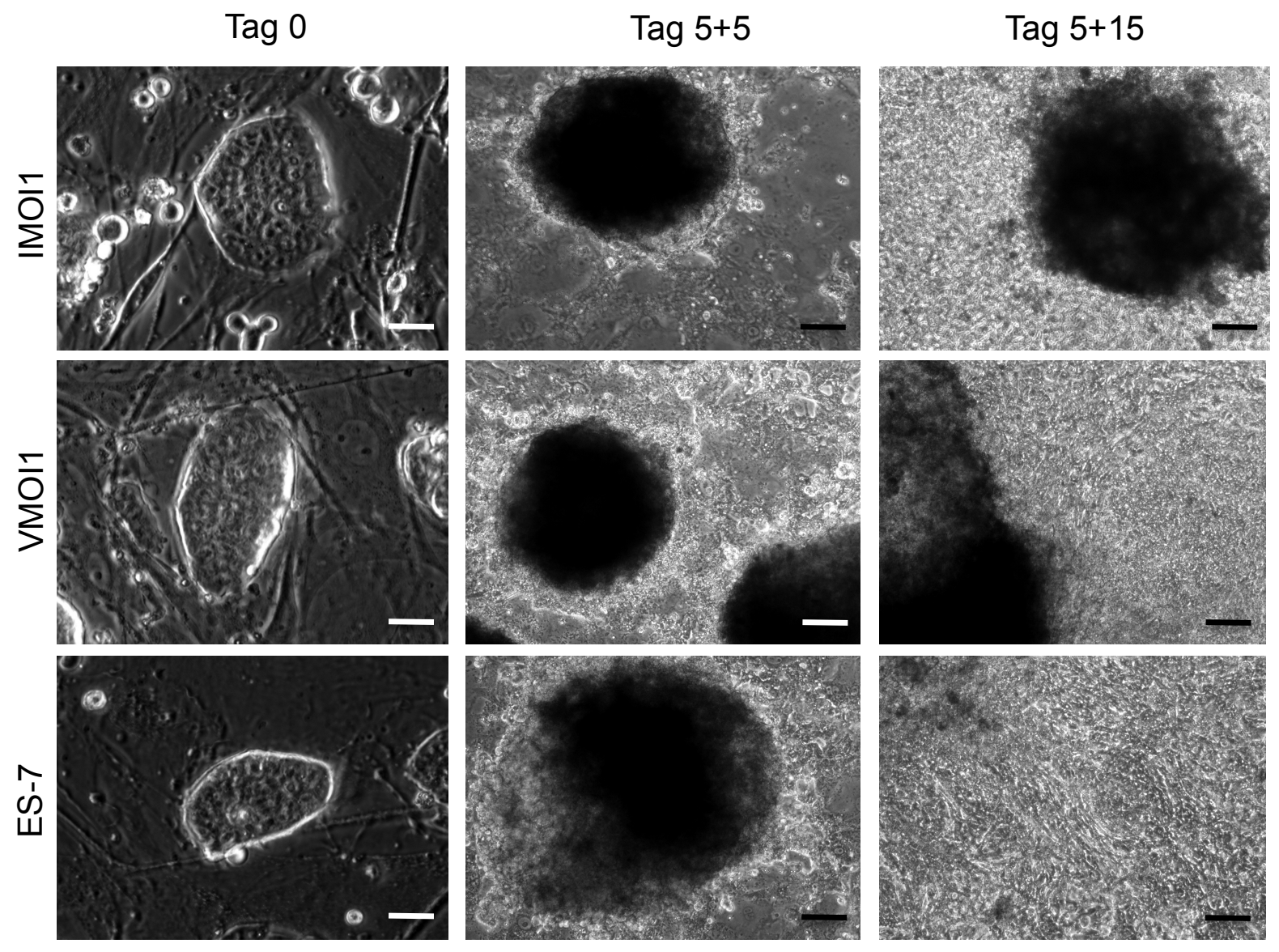

Abb. 11: Morphologie der IMOI1-, VMOI1- und ES-7-Zellen während der Differenzierung.

Zum Zeitpunkt Tag 0 zeigten alle drei Zelllinien im undifferenzierten Zustand Zellkolonien mit einer runden bis ovalen kompakten Zellkoloniestruktur und einem aufgehellten Rand. Zehn Tage nach der EB-Bildung zeigten die EBs eine charakteristische „Kopfsteinpflasterstruktur“. Zum Zeitpunkt Tag 20 konnte ein von den EBs ausgehendes peripheres Zellwachstum beobachtet werden, wobei die drei Zelllinien eine heterogene Morphologie aufwiesen. Skalierung: $100 \mu \mathrm{m}$. 
Zur Analyse des Differenzierungspotenzials der iPS- und ES-Linien auf mRNAEbene wurden Proben der Zellen im undifferenzierten Zustand (Tag 0) und im differenzierten Zustand zu den Zeitpunkten Tag 5 sowie Tag 5+15 genommen. Die RNA der Zellproben wurde isoliert und unter Verwendung von RT-PCR auf spezifische Marker der einzelnen Keimblätter untersucht (Abb. 12).

Die mesodermale Differenzierung konnte durch Expression des kardial-spezifischen Markers $\alpha-M h c$ bestätigt werden. Die $\alpha$-Mhc Expression konnte für IMOI1, VMOI1 und ES-7 ausschließlich an Tag 5+15 gezeigt werden. Der Hepatozyten-spezifische Marker a-Fetoprotein (Afp) zeigte mittels seiner Expression eine endodermale Differenzierung. Afp war ebenfalls bei allen drei untersuchten Zelllinien an Tag 5+15 exprimiert, bei VMOI1 etwas schwächer als bei IMOI1 und ES-7. Die Expression des neuronalen Markers achaete-scute complex like 1 (Ascl1/Mash1) zeigte letztendlich die ektodermale Differenzierungsfähigkeit. Mash1 konnte bei den Zelllinien IMOI1 und ES-7 zu den Zeitpunkten Tag 5 und Tag 5+15 nachgewiesen werden, bei der iPS-Linie VMOI1 zeigte sich eine Expression ausschließlich an Tag 5.

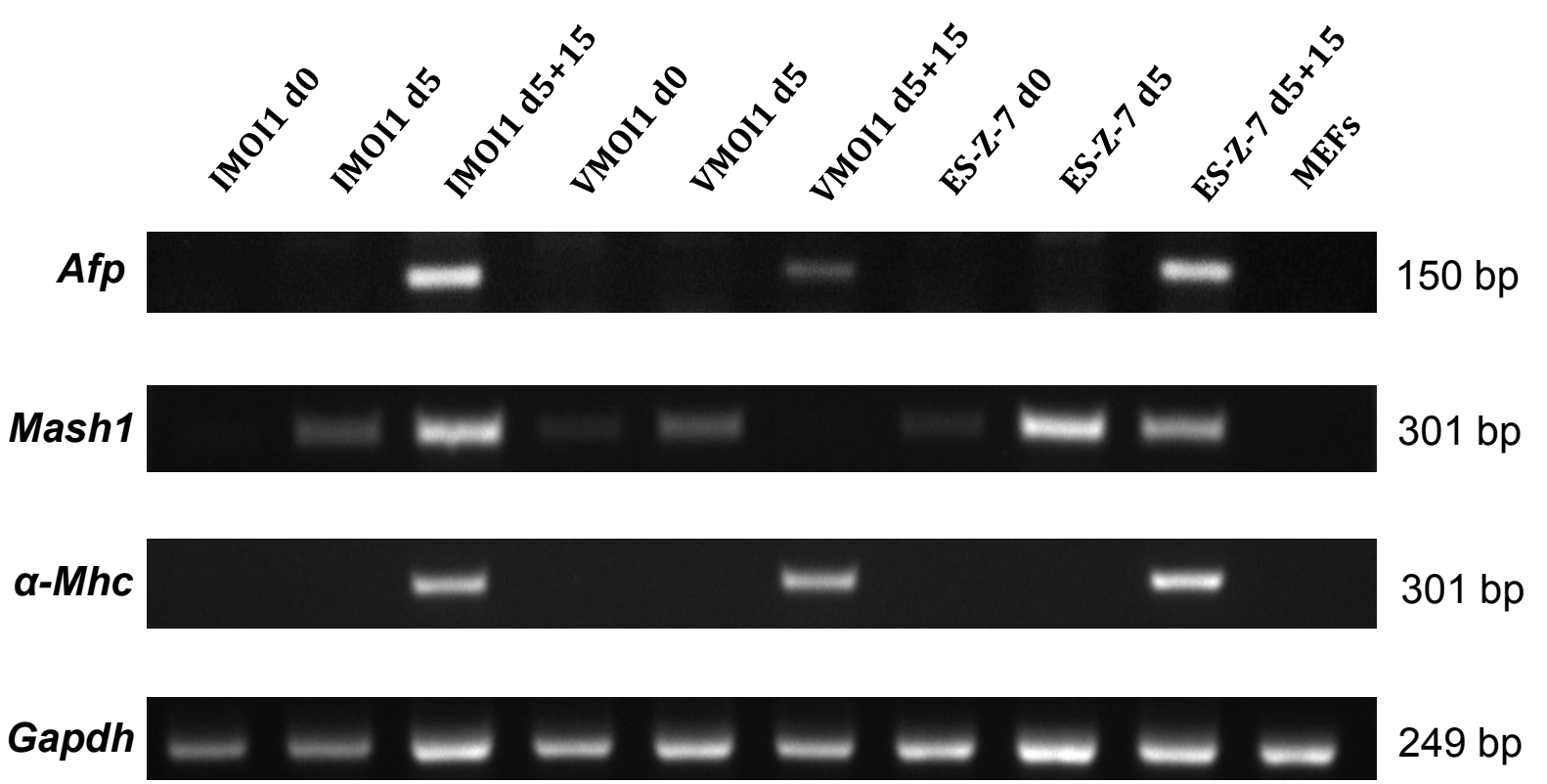

Abb. 12: Genexpressionsanalyse zur Differenzierung der Zelllinien IMOI1, VMOI1 und ES-7.

Die Analyse zeigte, dass alle drei Zellinien im Laufe der Zeit endodermal (Marker: Afp), ektodermal (Marker: Asc/1/Mash1) und mesodermal (Marker: $\alpha-M h c)$ differenzierten, wobei die VMOI1-Zellen eine schwache bis fehlende Expression von Mash1 zeigten. Die Expressionsanalyse erfolgte mit undifferenzierten Zellen (Tag 0), mit EB`s (Tag 5) und gewachsenen EB`s (Tag 5+15). Gapdh diente als interner Standard. 
Zusammenfassend lässt sich sagen, dass die Pluripotenz der Zelllinien IMOI1, VMOI1 und ES-7 bewiesen werden konnte. Dies erfolgte durch den Nachweis ihrer Morphologie, der alkalischen Phosphataseaktivität und der Expression typischer Stammzellmarker. Des Weiteren konnte auch in der In-vitro-Differenzierung gezeigt werden, dass eine Differenzierung mittels hanging drop-Methode erfolgte bzw. die Zellen endo-, meso- und ektodermale Marker auf mRNA-Ebene exprimieren.

\subsection{Analyse der Zellproliferation}

Die Proliferation der miPS IMOI1 und VMOI1 sowie der mES ES-7 wurde durch eine Zellzählung mittels Thoma neu Zählkammern zu drei verschieden Zeitpunkten (Tag 1, Tag 2, Tag 3) ermittelt. Die Analyse erfolgte ausgehend von einer Anfangszellzahl von 50.000 Zellen und es wurden für jede Zelllinie $n=3$ Versuche durchgeführt, die Zellen wurden auf $0,1 \%$ Gelatine kultiviert.

Ausgehend von 50.000 Zellen pro Zellinie, ausplattiert am Tag 0 , waren die Wachstumsraten in jedem Falle von Tag 0 zu Tag 1 niedrig; die Wachstumsrate für ES-7 fiel geringfügig höher aus. Die Unterschiede waren an Tag 1 statistisch nicht signifikant $(p>0,05)$. Zum Zeitpunkt Tag 1 lag der Wert für IMOI1-Zellen bei $53.667 \pm$ 1.528, für VMOI1-Zellen ebenfalls bei $53.667 \pm 3.055$ und für ES-7 $66.667 \pm 13.868$.

Die stärkste Proliferation mit einer nahezu Verdopplung der Zellzahl zeigte die ES-7 von Tag $1 \mathrm{zu}$ Tag 2. Eine wesentlich geringere Zunahme der Zellzahl in diesem Zeitraum zeigten die iPS mit 28\% (IMOI1) bzw. 45\% (VMOI1). Der Unterschied in den Zellzahlen am Tag 2 zwischen den ES-7 einerseits und den iPS andererseits war statistisch signifikant $(p<0,05)$. An Tag 2 betrugen die Mittelwerte für IMOI1 Zellen $68.667 \pm 2.309$, für VMOI1 Zellen $78.000 \pm 28.844$ und für ES-7 $130.333 \pm$ 26.658.

Während die Wachstumskurve für ES-7 zwischen Tag 2 und Tag 3 abflachte - die Zunahme der Zellzahl betrug in diesem Falle 22\% - und auch die Proliferation von IMOI1 nur gering zunahm (7\%), gab es einen sehr ausgeprägten Anstieg der Zellzahl in diesem Zeitraum für die VMOI1 (135\%). Die Unterschiede in den Zellzahlen zwischen ES-7 und IMOI1 $(p<0,05)$ bzw. zwischen VMOI1 und IMOI1 $(p<0,01)$ waren statistisch signifikant. Die Zellzahlen von ES-7 und VMOI1 $(p>0,05)$ unterschieden sich nicht signifikant. An Tag 3 ergaben sich die folgenden Mittelwerte für die 
Zellzahlen: IMOI1 Zellen $73.333 \pm 3.512$, VMOI1 Zellen $183.667 \pm 35.501$ und ES-7 $158.667 \pm 39.273$ (Abb. 13).

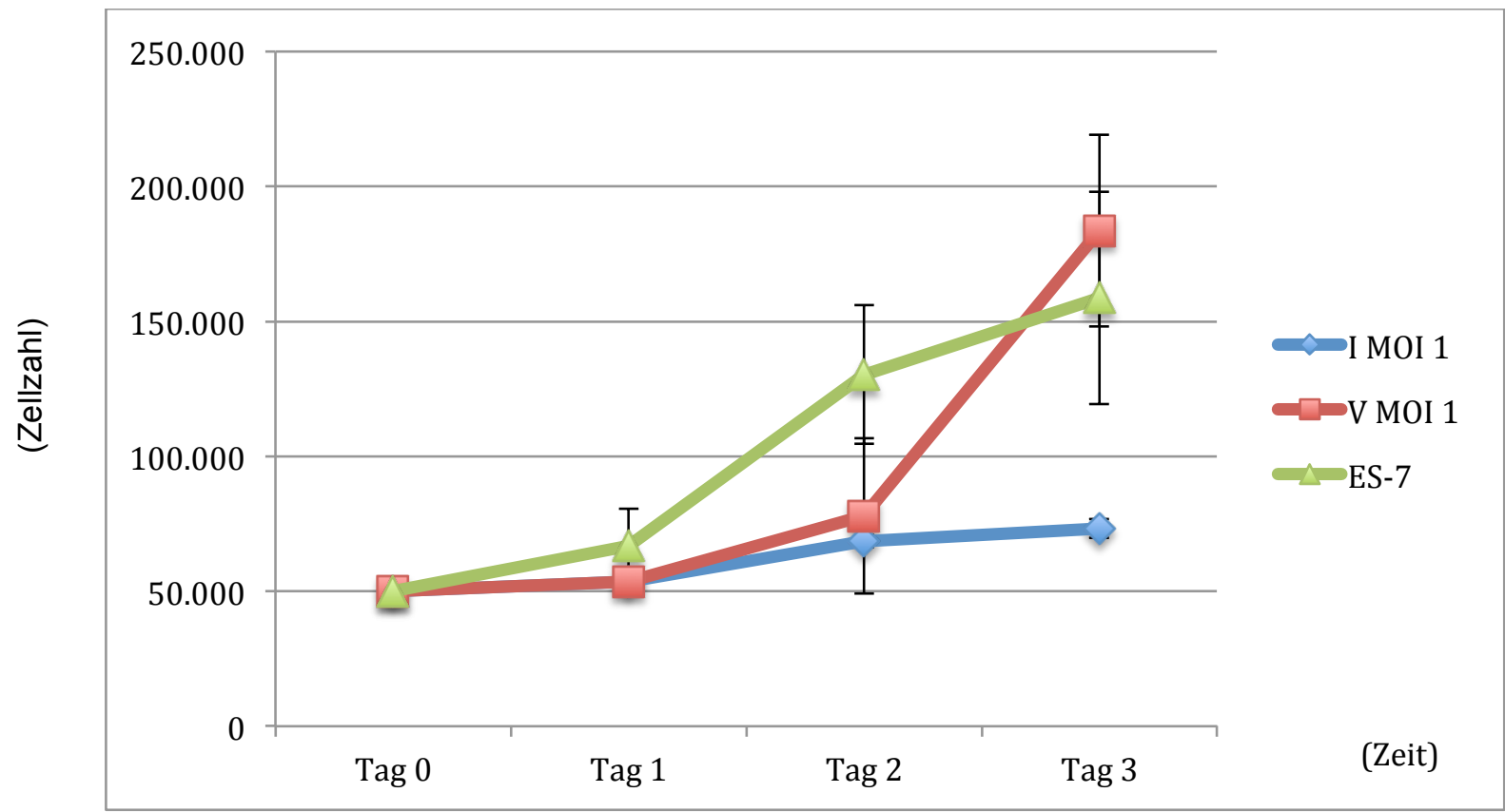

Abb. 13: Zellproliferationsanalyse der Zellen IMOI1, VMOI1 und ES-7.

Alle drei Zelllinien zeigten über den analysierten Zeitraum ein kontinuierliches Wachstum. Hierbei ähnelten sich die Werte von VMOI und ES-7 zum final analysierten Zeitpunkt (Tag 3). IMOI1 lag mit 73.333 (an Tag 3) deutlich darunter. Es wurden $n=3$ Versuche pro Zelllinie untersucht. Angegeben sind Mittelwerte \pm Standardabweichungen.

Die Verdopplungszeit ermittelt aus der halb-logarithmischen (In) Darstellung der Wachstumskurven betrug für die IMOI1 119,6 std, für die VMOI1 34,1 std und für die ES-7 41,5 std.

\subsection{Karyotypisierung der analysierten miPS-Linien und mES-Linie}

Die Karyotypisierung wurde mit den miPS-Linien IMOI1 und VMOI1 sowie der mESLinie ES-7 nach >20 Passagen durchgeführt. Durch diese Analyse sollten numerische Chromosomen-Aberrationen nach Langzeitkultivierung ausgeschlossen werden. Es wurden für alle drei Zelllinien die Metaphase-Chromosomen von je ca. 30 Zellen analysiert. Die Morphologie der Zelllinien IMOI1, VMOI1 und ES-7 zeigte lichtmikroskopisch keine Unterschiede (Abb. 14). 

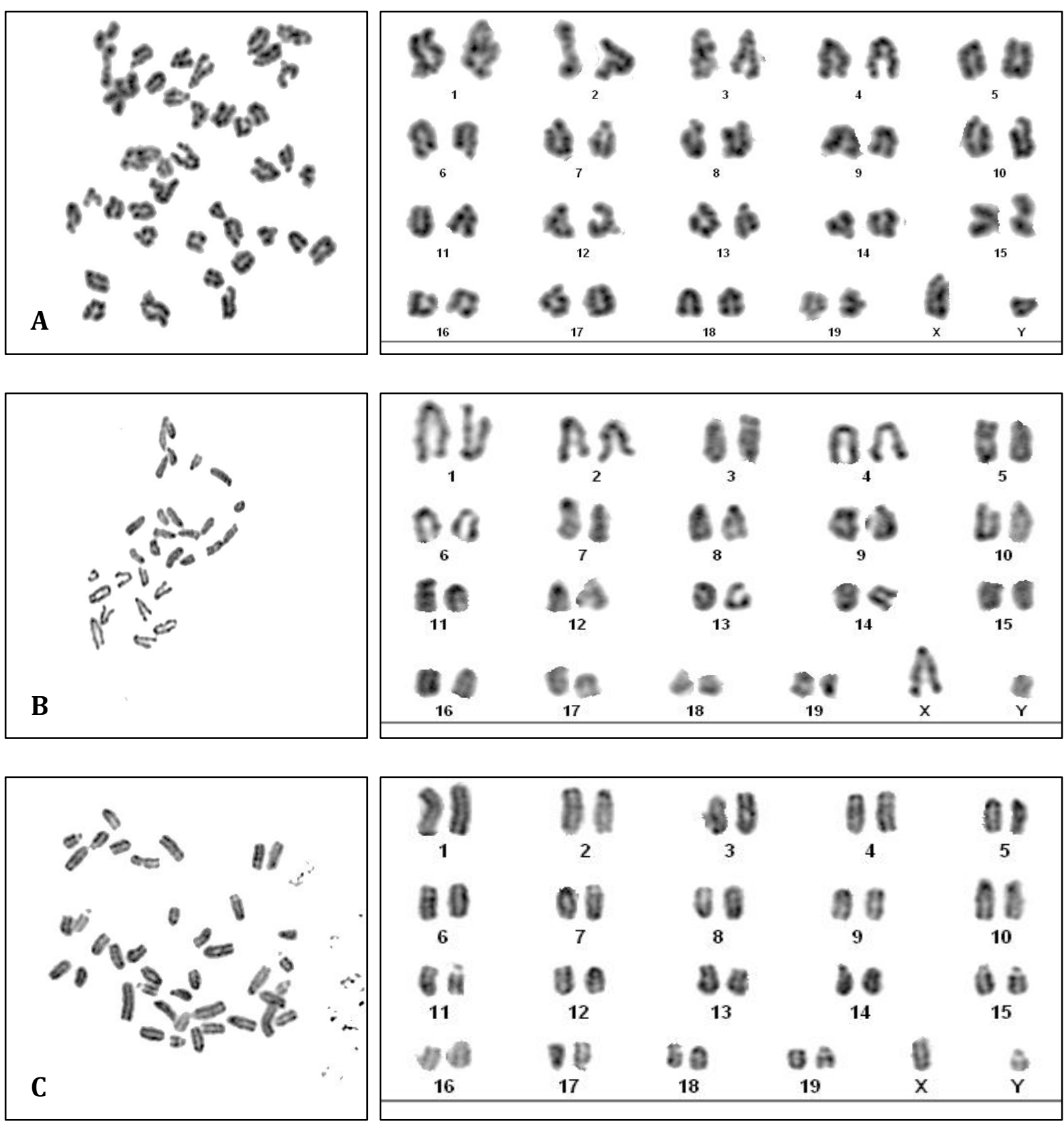

Abb. 14: Analyse des Karyotyps der Zelllinien, A: IMOI1, B: VMOI1, C: ES-7.

Alle drei untersuchten Zellinien zeigten physiologische Chromosomensätze nach LangzeitKultivierung $(p>20)$. Links sind die Metaphase-Chromosomen und rechts die zugehörigen Karyogramme dargestellt.

Die folgende Tab. 8 gibt einen Überblick über die Karyotyp-Analysen der Zellen IMOI1, VMOI1 und ES-7. IMOI1 und ES-7 zeigten jeweils bei 25 analysierten Zellen den Karyotyp 40, XY. VMOI1 zeigte den Karyotyp 40, XY bei 29 Zellen. Bei VMOI1 und ES-7 wurde bei je einer Zelle eine Aberration festgestellt, bei IMOI1 bei zwei Zellen. 
Generell konnte die Karyotypisierung einen physiologischen Karyotyp trotz Langzeitkultivierung der analysierten Zelllinien zeigen.

Tab. 8: Karyotypisierung der Zellen IMOI1, VMOI1 und ES-7.

\begin{tabular}{|c|c|c|c|c|}
\hline & Karyotyp & Zellzahl & Aberration & Zellzahl \\
\hline I MOI 1 & $40, X Y$ & 25 & $43, X Y$ & 2 \\
\hline V MOI 1 & $40, X Y$ & 29 & $25, X Y$ & 1 \\
\hline ES-Z-7 & $40, X Y$ & 25 & $53, X Y$ & 1 \\
\hline
\end{tabular}

\subsection{Kardiale Differenzierung der miPS-Linien und mES-Linie}

Die kardiale Differenzierung der miPS-Linien IMOI1 und VMOI1 sowie der mES-Linie ES-7 wurde qualitativ und quantitativ untersucht. Hierzu wurde ein Nachweis von kardialen Markern auf mRNA- und Proteinebene durchgeführt. Die quantitative Analyse erfolgte anhand einer Durchflusszytometrie.

\subsubsection{Gen- und Proteinexpression kardialer Marker}

Die Expression der kardialen Marker der frühen und späten Entwicklung Gata4, NK2 homebox 5 (Nkx2.5), a-Mhc, myosin regulatory light chain 2 ventricular isoform (MIc2v) und atrialer natriuretischer Faktor (Anf) wurde bei den Zelllinien IMOI1, VMOI1 und ES-7 zum Zeitpunkt Tag 22 analysiert. Als interner Standard diente Gapdh. Die Zellen wurden anhand der hanging drop-Methode differenziert und durch G418 selektiert. Die Kultivierung erfolgte auf mit 0,1\% Gelatine beschichteten Zellkulturschalen. An Tag 22 wurde die RNA der Zellen isoliert und die Expression der kardialen Marker durch eine RT-PCR analysiert. Für die miPS IMOI1 und VMOI1 wurden jeweils $n=3$, für die mES $n=2$ Differenzierungsversuche betrachtet.

Die frühen kardialen Marker Gata4 und Nkx2.5 wurden nur bei je einem Differenzierungsversuch von IMOI1 und ES-7 stark exprimiert; VMOI1 zeigte eine schwache Expression. Die späten kardialen Marker $\alpha-M h c, M l c 2 v$ und Anf wurden bei allen Differenzierungsversuchen der drei Zelllinien exprimiert (Abb. 15). 


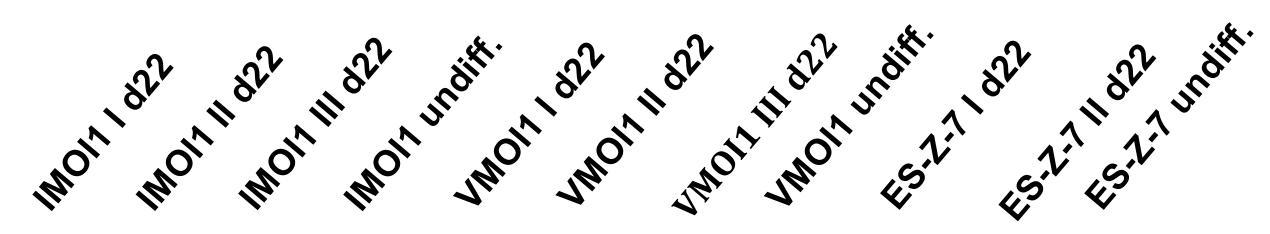

Gata4

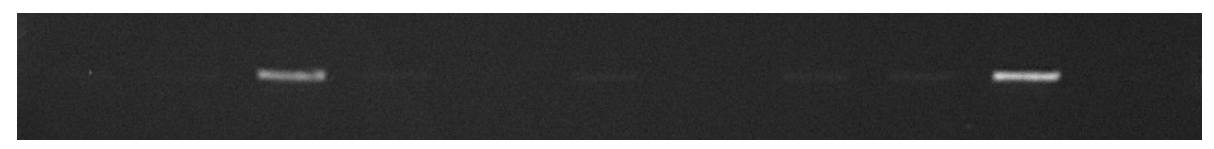

$256 \mathrm{bp}$

Nkx2.5

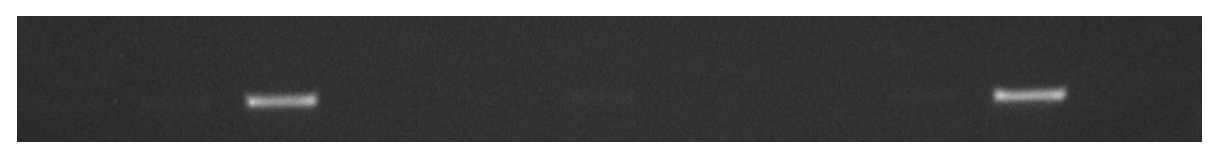

217 bp

$\alpha-M h c$

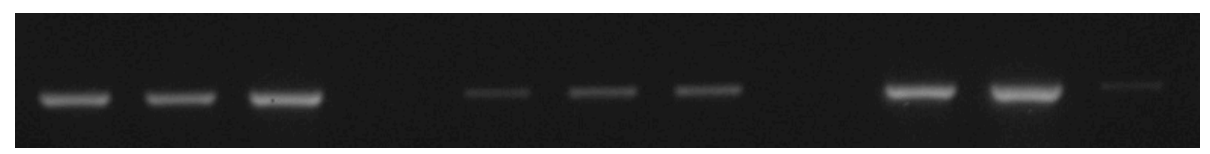

301 bp

$M l c 2 v$

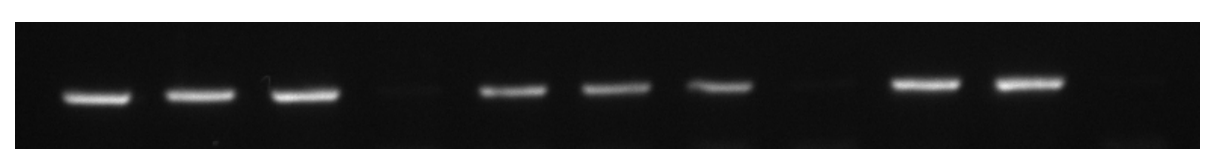

189 bp

Anf

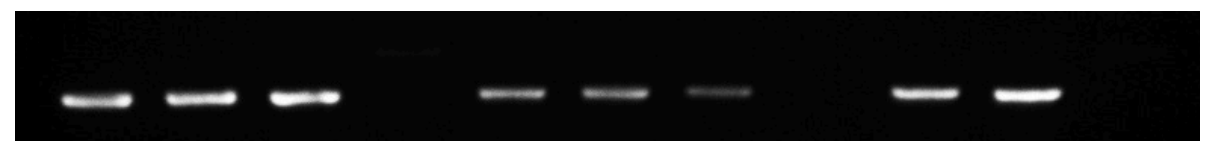

203 bp

Gapdh

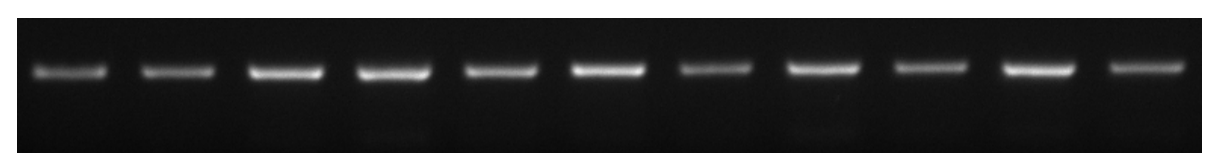

249 bp

Abb. 15: Genexpressionsanalyse kardialer Marker in den Zellen IMOI1, VMOI1 und ES-7.

Die frühen kardialen Marker Gata4 und Nkx2.5 wurden nur bei je einem Differenzierungsversuch von IMOI1 und ES-7 stark exprimiert; VMOI1 zeigte eine schwache Expression. Die späten kardialen Marker $\alpha$-Mhc, Mlc2v und Anf wurden bei allen Differenzierungsversuchen der drei Zelllinien exprimiert. Als Negativkontrolle dienten die undifferenzierten IMOI1, VMOI1 und ES-7. Gapdh wurde als interner Standard verwendet.

Die Expression kardialer Marker wurde ebenfalls auf Protein-Ebene mit Hilfe einer $\alpha-$ Aktinin Immunfluoreszenzfärbung an den Zelllinien IMOI1, VMOI1 und ES-7 an Tag 22 analysiert. Die Zellen wurden wie bei der RT-PCR-Analyse durch die hanging drop-Methode differenziert und durch G418 selektiert. Davon abweichend erfolgte dann nach Verdau ihre Kultivierung auf MEF-beschichteten chamber slides und eine erneute G418-Selektion bis zum Erreichen von Tag 22.

Es konnte gezeigt werden, dass die ausgehend von IMOI1, VMOI1 und ES-7 differenzierten Gfp-positiven Kardiomyozyten a-Aktinin exprimieren. Des Weiteren 
konnte eine physiologische Morphologie und Herzmuskel-typische Querstreifung gezeigt werden. Die Darstellung der Zellkerne erfolgte durch die Zellkernfärbung mit DAPI (Abb. 16a-c).

\section{IMOI1 (d22)}

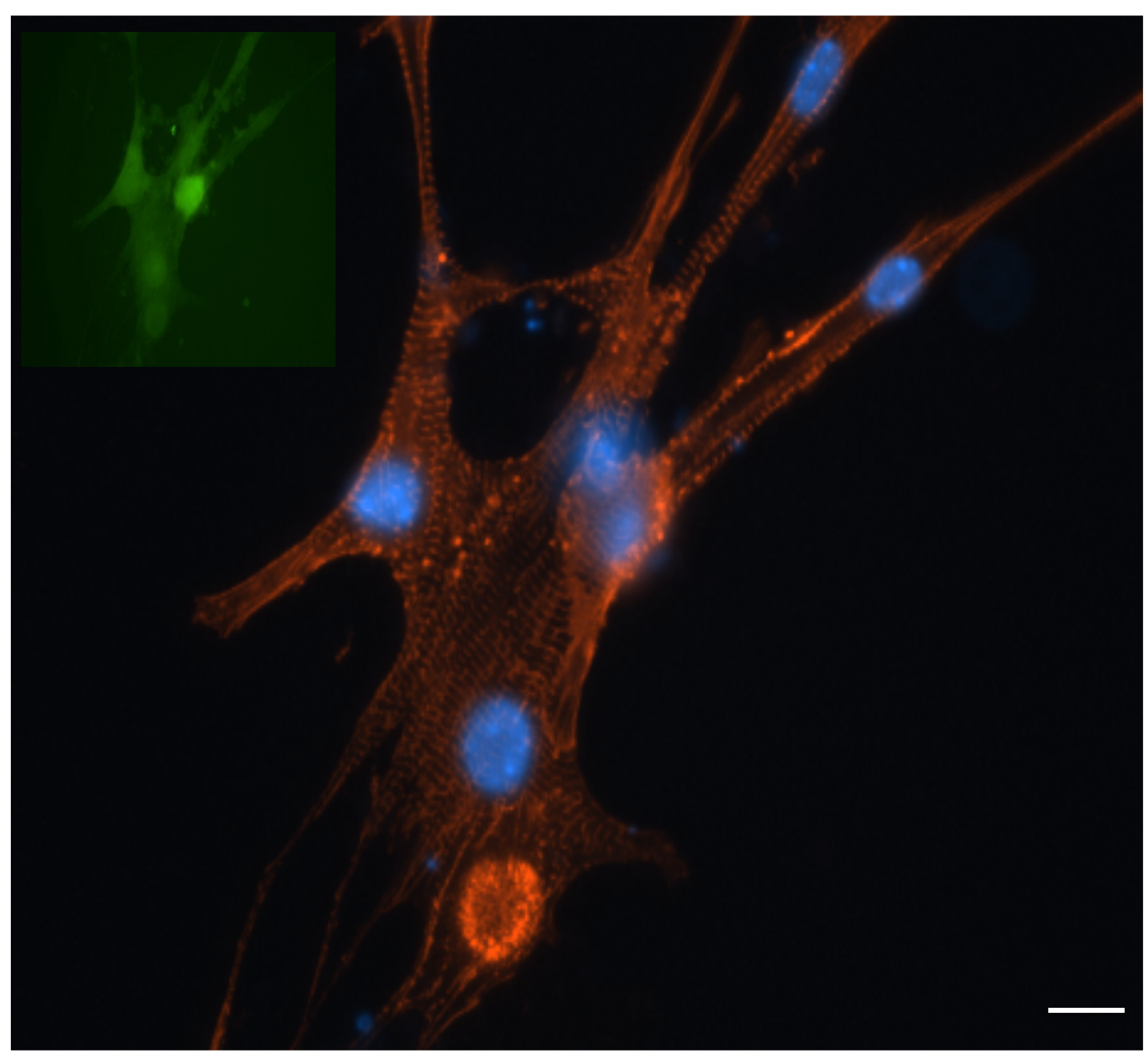

Alpha-act./Dapi (FITC)

Abb. 16a: Immunfluoreszenzfärbung des kardialen Markers $\alpha$-Aktinin in der Zelllinie IMOI1. 


\section{VMOI1 (d22)}

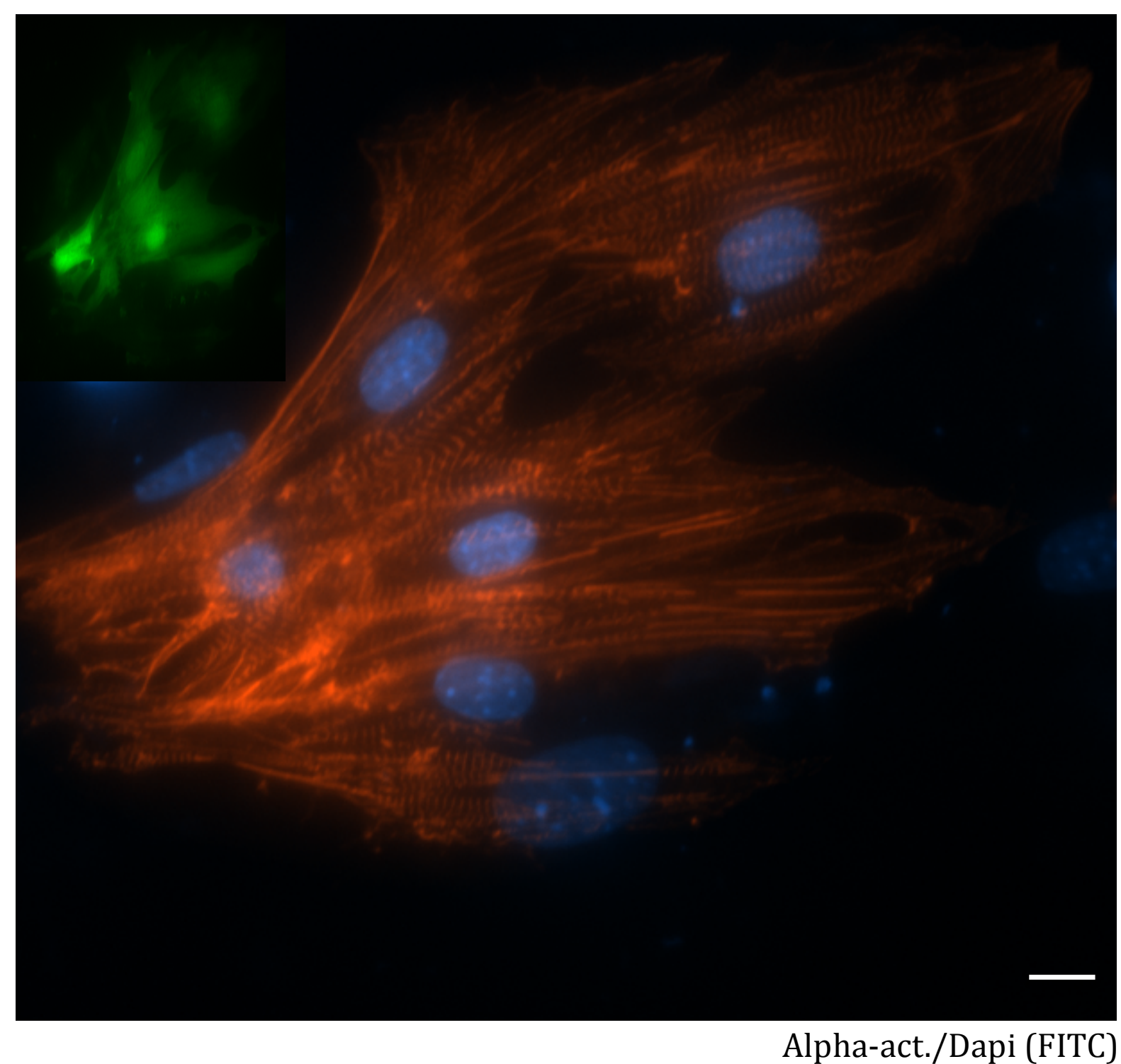

Abb. 16b: Immunfluoreszenzfärbung des kardialen Markers $\alpha$-Aktinin in der Zelllinie VMOI1. 


\section{ES-Z-7 (d22)}

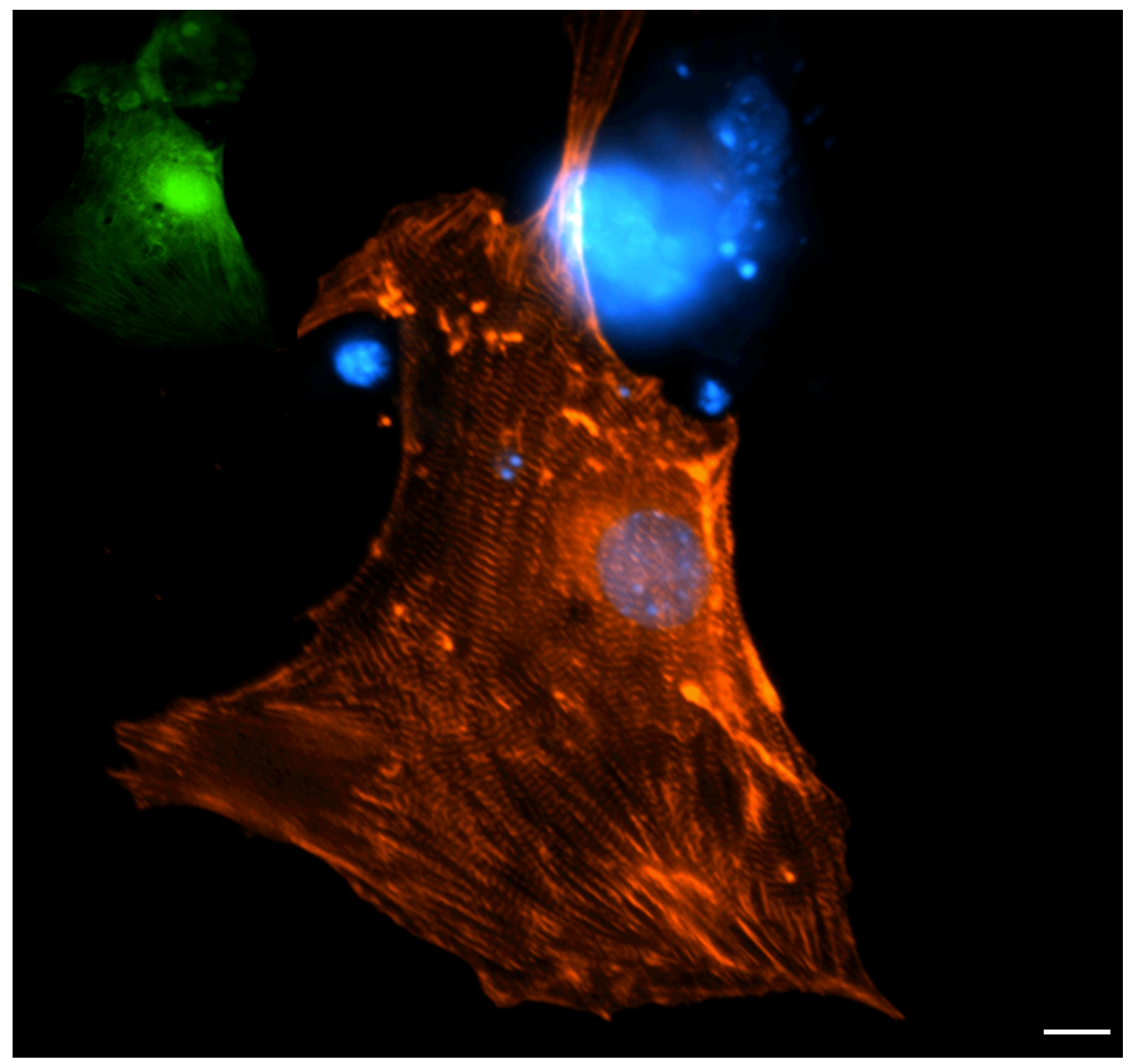

Alpha-act./Dapi (FITC)

Abb. 16c: Immunfluoreszenzfärbung des kardialen Markers $\alpha$-Aktinin in der Zelllinie ES-7.

Alle drei Zelllinien konnten eine kardiale Differenzierung und somit die Expression von a-Aktinin (rot) vorweisen, außerdem waren sie Gfp-positiv. Die Zellen waren zum untersuchten Zeitpunkt 22 Tage alt. Die Zellkerne wurden mit DAPI (blau) gefärbt. Skalierung: $20 \mu \mathrm{m}$.

\subsubsection{Quantitative Analyse des Kardiomyozytenanteils der In-vitro- Differenzierung}

Die quantitative Analyse der differenzierten Kardiomyozyten erfolgte anhand einer Durchflusszytometrie. Hierzu wurden die Zellen IMOI1, VMOI1 und ES-7 zu drei 
verschiedenen Zeitpunkten (Tag 10, 15 und 22) analysiert. Bei jeder Zelllinie wurden 4 Versuche $(n=4)$ durchgeführt.

Die Versuche erfolgten ebenfalls mittels hanging drop-Methode; die Zellen wurden jedoch nicht G418 selektiert, um den eGfp-positiven prozentualen Anteil an der gesamten Zellpopulation eines Differenzierungsversuches bestimmen zu können.

A

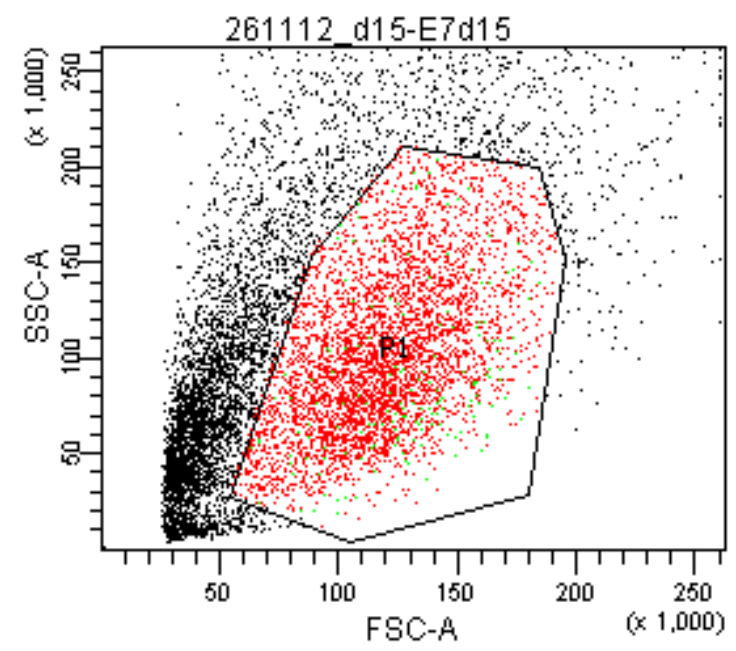

B

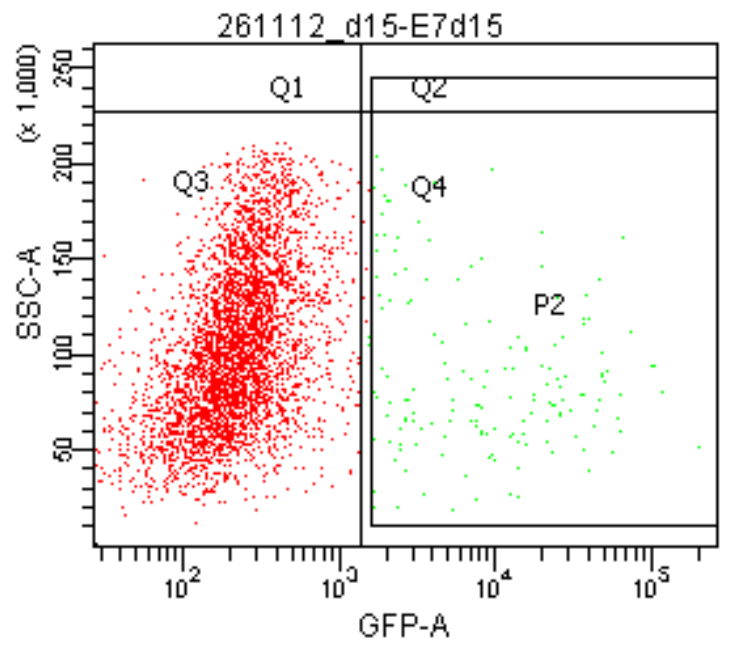

Abb. 17: Darstellung der durchflusszytometrischen Ergebnisse anhand des Beispiels ES-7 zum Zeitpunkt Tag 15.

Abbildung A: Dot plot der analysierten Zellpopulation. Abbildung B: Darstellung der gates eGfppositiver (grün) und -negativer Zellen (rot).

Bei der folgenden Ermittlung der eGfp-positiven Zellen wurden die arithmetischen Mittelwerte mit den zugehörigen Standardabweichungen (SD) errechnet. An Tag 10 der kardialen Differenzierung waren 1,6\% \pm 0,6\% der ES-7 eGfp-positiv. Dieser Prozentsatz stieg bis zu Tag 22 auf 5,7\% \pm 5,0\% an. Das Differenzierungsverhalten der IMOI1 und VMOI1 war an Tag 10 mit 0,7\% 0,5\% bzw. 0,7\% 0,4\% und an Tag 15 mit 2,1\% $\pm 0,9 \%$ bzw. 1,9\% $\pm 0,7 \%$ ähnlich. An Tag 22 war der Anteil an eGfppositiven Zellen bei den VMOI1 Zellen mit 7,4\% 4 4,9\% deutlich höher als bei den IMOI1 Zellen mit 5,8\% $\pm 3,4 \%$. Dieser Unterschied war statistisch nicht signifikant $(p>0,05)$. Als Negativkontrolle diente die eGfp-freie Zelllinie ES-9 (Abb. 18). 


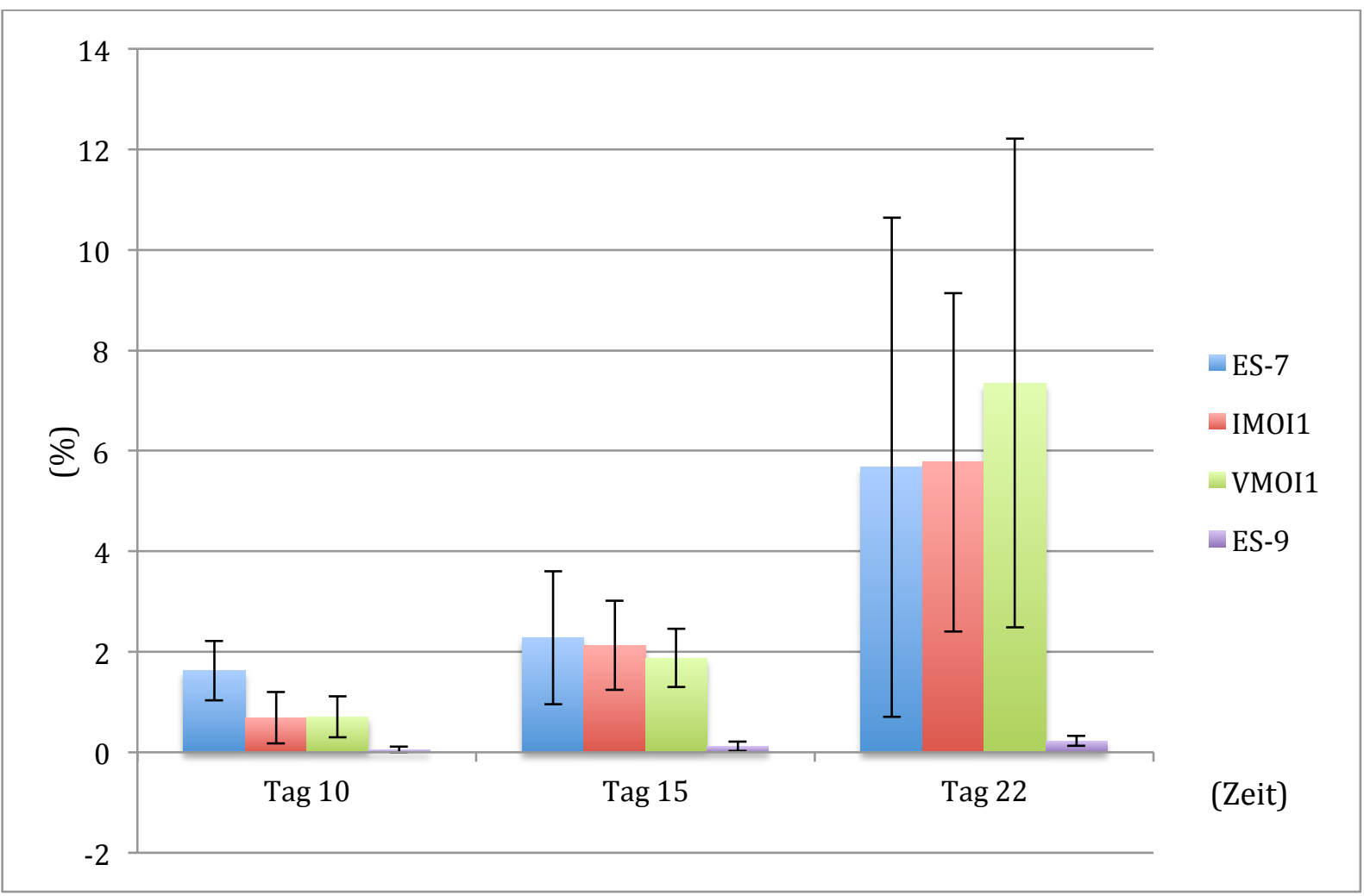

Abb. 18: Quantitative Bestimmung des Kardiomyozytenanteils in Differenzierungskulturen der Zellen IMOI1, VMOI1 und ES-7.

Angegeben sind die Prozentwerte eGfp-positiver Zellen als Mittelwerte mit Standardabweichung an Tag 10, 15 und 22 im Vergleich zur eGfp-freien Negativkontrolle ES-9.

Während die Differenzierungsversuche für die Durchflusszytometrie ohne eine Antibiotikaselektion erfolgten, wurde zusätzlich der Anteil eGfp-positiver Kardiomyozyten nach Antibiotikaselektion bestimmt. Dies erfolgte über ein Auszählen von DAPI-positiven bzw. DAPI-a-Aktinin-positiven (doppelt-positiven) Zellen nach Immunfluoreszenzfärbung. Diese Analyse zeigte, dass der Anteil doppelt-positiver Zellen bei ES-7 bei 84,1\% ( $n=4)$ lag. Bei den miPS betrug der Anteil doppelt-positiver Zellen bei IMOI1 79,4\% ( $n=4)$ und bei VMOI1 81,4\% $(n=4)$.

Die qualitative Analyse der differenzierten Kardiomyozyten zeigte, dass alle drei Zelllinien bezogen auf die mRNA- und Protein-Expression keine wesentlichen Unterschiede aufwiesen. Beim kardialen Outcome zeigten sich keine Unterschiede zwischen IMOI1, VMOI1 und ES-7, vor allem jedoch eine große Varianz zwischen den einzelnen analysierten Versuchen. 


\section{Diskussion}

In dieser Arbeit wurden drei murine Zelllinien - eine mES (mES-7) und zwei miPS (IMOI1 und VMOI1) - im undifferenzierten Zustand in Hinblick auf ihre Morphologie und ihr Wachstumsverhalten miteinander verglichen. Es wurden ihre Reprogrammierung geprüft und Pluripotenz anhand von Pluripotenzmarkern analysiert. Auch das Differenzierungspotential in die drei Keimblätter wurde mithilfe der RT-PCR-Methode gezeigt. Darüber hinaus wiesen die einzelnen Zelllinien auch nach längerer Kultivierung einen physiologischen Karyotyp auf. Mit diesen vorhandenen Eigenschaften der undifferenzierten Zellen war grundsätzlich eine wesentliche Voraussetzung für eine erfolgreiche Differenzierung in Kardiomyozyten gegeben. Des Weiteren wurde in dieser Arbeit die Differenzierung der mES-7 und miPS IMOI1 und VMOI1 in Kardiomyozyten vorgenommen, ihre Morphologie, die Expression herzspezifischer Proteine und das Differenzierungs-Outcome der Herzmuskelzellen analysiert. Ferner wurde überprüft, ob die untersuchten Zelllinien sich für eine Zell-basierte Therapie eignen bzw. inwiefern sich die generierten miPSLinien IMOI1 und VMOI1 von der mES-Linie mES-7 unterscheiden.

Unter Zell-basierte Therapien wird eine Fülle unterschiedlicher Ansätze subsummiert. Gerade den patientenspezifischen iPS wird wegen ihrer großen Ähnlichkeit zu ES und wegen des schwierigen Handlings der seltener zur Verfügung stehenden adulten Stammzellen eine hohe Bedeutung als Ursprungszellen für mögliche Zell-basierte Therapieansätze beigemessen (Dimos et al. 2008; Park et al. 2008). Um diese zu generieren, bietet sich die Reprogrammierungstechnik unter Verwendung somatischer Zellen wie Keratinozyten oder Fibroblasten an (Ebert et al. 2009; Bellin et al. 2012; Novak et al. 2012; Streckfuss-Bomecke et al. 2013; Sun et al. 2012).

\subsection{Reprogrammierung somatischer Zellen in iPS}

Die analysierten Zelllinien wurden aus Fibroblasten mit den Transkriptionsfaktoren OCT4, SOX2, c-MYC und KLF4 über einen lentiviralen Vektor mittels STEMCCASystem reprogrammiert.

Im Jahr 2006 gelang Takahashi und Yamanaka erstmals die Generierung sog. miPS. Die Autoren folgten damit dem Prinzip, über eine Reprogrammierung differenzierter Zellen diese in einen Embryonalzell-ähnlichen Zustand zurückzuführen. Die 
Reprogrammierung selbst ist ein langsamer und ein stufenweise ablaufender Prozess. Um die Reprogrammierung somatischer Zellen und ihre Pluripotenz zu erreichen, müssen dafür verantwortliche vier (OCT4, KLF4, SOX2, c-MYC) Transkriptionsfaktoren zusammen mit vier unabhängigen retroviralen Vektoren zugeführt werden (Takahashi \& Yamanaka 2006; Maherali et al. 2007; Okita et al. 2007; Takahashi et al. 2007; Wernig et al. 2007; Yu et al. 2007). Nachteilig an diesem Verfahren ist, dass in den reprogrammierten Zellen integrierte Transgene verbleiben. Die Reaktivierung oder langandauernde Expression dieser Transgene kann schädliche Auswirkungen wie Tumorbildung (Okita et al. 2007) oder Verlust der Pluripotenz (Niwa et al. 2000; Kopp et al. 2008) mit sich bringen. Deshalb war die Gewinnung muriner iPS ohne die Verwendung von Viren naheliegend und im Prinzip erfolgreich (Okita et al. 2008; Stadtfeld et al. 2008). Leider war aber die Ausbeute an gewonnenen reprogrammierten Zellen sehr gering. Verwendet man aber einen einzelnen lentiviralen polyzistronischen (eine einzelne mRNA codiert mehrere unterschiedliche Proteine) Vektor (STEMCCA), fusioniert mit den Mausgenen KIf4, Oct4, Sox2 und c-Myc, kann man die Zahl proviraler Integrationen minimieren, eine deutlich höhere Reprogrammierungseffizienz als mit der Multi-Virus-Transduktion erreichen und die virale Reprogrammierungs-Kassette aus den iPS exzidieren (Sommer et al. 2009; Somers et al. 2010).

In diesem Zusammenhang ergeben sich bei dem eigenen experimentellen Vorgehen immer wieder die Fragen, wie gut eigentlich die Reprogrammierung gelingt, wie vollständig sie ist und ob die Zellen tatsächlich pluripotent sind.

\subsection{Nachweis der Pluripotenz}

Die Analyse der generierten murinen Zellen konnte sowohl bei den iPS-Linien IMOI1 und VMOI1, die aus MEFs der Maus stammten, als auch bei der ES-7-Linie, die als undifferenzierte Zellen aus der ICM der Blastozyste (Evans \& Kaufman 1981; Martin 1981) gewonnen worden waren, den Nachweis der Pluripotenz liefern. Die Zellen befanden sich, um den undifferenzierten Zustand erhalten zu können, auf mitotisch inaktivierten MEFs als Feeder-Zellen (Thomson et al. 1998). 


\subsubsection{Expression der Pluripotenzmarker}

Der Nachweis der Pluripotenz erfolgte zum einen über die alkalische Phosphataseaktivität der Zellen, zum anderen wurde die Expression verschiedener Pluripotenzmarker auf mRNA-Ebene mittels PCR und auf Proteinebene mittels Immunfluoreszenz überprüft. Die untersuchten murinen iPS IMOI1 und VMOI1 bzW. die murinen ES-7 zeigten eine typische Morphologie und eine rege Aktivität der alkalischen Phosphatase. Die alkalische Phosphatase ist ein wichtiger Pluripotenzmarker, da phänotypisch undifferenzierte ES sowohl muriner als auch humaner Herkunft neben verschiedenen anderen Enzymaktivitäten eine alkalische Phosphataseaktivität aufweisen (Wobus et al. 1984; Thomson et al. 1998).

Die Reprogrammierungsfaktoren und zusätzlichen Pluripotenzmarker (Lin28, Rex1, Nanog und Oct4) für undifferenzierte ES waren in den embryonalen Stammzellen bzw. in den Zellen, die der embryonalen Stammzelle ähnlich sind, nachzuweisen.

Das Lin28-Protein wird von dem Gen Lin28 codiert. Dieses ist sowohl in humanen (Richards et al. 2004) als auch in murinen ES (Yang et al. 2003) stark exprimiert.

Das Rex1 (Zfp-42)-Protein wurde von Hosler et al. (1989) in murinen F9 Teratokarzinom-Zellen entdeckt und gilt als wichtiger Pluripotenzmarker (BenShushan et al. 1998). Sobald die Zellen zu differenzieren beginnen, wird Rex1 stark und abrupt herunterreguliert (Wang et al. 2006).

Das Nanog-Protein wird von dem Pluripotenzgen Nanog codiert. Es ist in die Selbsterneuerung sowohl von murinen als auch embryonalen Stammzellen involviert (Chambers et al. 2003; Mitsui et al. 2003) und gehört zu den Schlüsselfaktoren für Pluripotenz. Dabei scheint Nanog mit den Transkriptionsfaktoren Klf4, Sox2 und Oct4 in regulatorischen Rückkopplungskreisen zu kooperieren (Boyer et al. 2005; Loh et al. 2006; Chen et al. 2008; Jiang et al. 2008; Kim et al. 2008). Ist das Nanog Protein nicht vorhanden, differenzieren murine pluripotente Stammzellen in endodermale Zellen (Chambers et al. 2003; Mitsui et al. 2003). Nanog-Null-Zellen tendieren zur spontanen Differenzierung (Mitsui et al. 2003). Somit verhindert die Überexpression von Nanog die Zelldifferenzierung. Interessanterweise ist der Transkriptionsfaktor Nanog für die Reprogrammierung entbehrlich (Takahashi \& Yamanaka 2006). 
Oct4 ist ein Transkriptionsfaktor, der in der ICM der sich entwickelnden Blastozyste exprimiert wird und einer der vier Faktoren, mit denen die Zellen reprogrammiert wurden. Zusammen mit Nanog ist Oct4 an der Steuerung der Selbsterneuerung und der Aufrechterhaltung der Pluripotenz embryonaler Stammzellen beteiligt (Scholer et al. 1990; Nichols et al. 1998; Niwa et al. 2000; Chambers et al. 2003; Mitsui et al. 2003; Rodda et al. 2005). Allerdings wird zur Aufrechterhaltung der Pluripotenz eine kritische Oct4 Konzentration benötigt; eine Repression von Oct4 führt zu einem Verlust der Pluripotenz, eine geringe Expression führt zu einer Differenzierung in Endo- und Mesoderm (Niwa et al. 2000). Während grundsätzlich drei der vier Faktoren durch andere ersetzt werden können, gilt dieses nicht für Oct4, das somit essentieller Bestandteil innerhalb der vier Faktoren ist (Heng et al. 2010). Das entsprechende Gen Oct4 gilt als Pluripotenzgen.

Die PCR-Untersuchungen ergaben, dass die Reprogrammierung zu miPS erfolgreich war, dass die miPS hinsichtlich der gemessenen Parameter den mES gleich, und dass diese Zellen pluripotent waren. Dieses konnte durch den Nachweis der Marker Lin28, Rex1, Nanog und Oct4 belegt werden. Insbesondere die Expression der Transkriptionsfaktoren Oct4 und Nanog sprach für das Vorhandensein undifferenzierter Zellen.

Die Expression von Lin28, Rex1, Nanog, Oct4 konnte in Fibroblasten, aus denen die miPS stammten, nicht detektiert werden.

Wegen der Verwendung des lentiviralen humanen STEMCCA Systems (Sommer et al. 2010) war es sinnvoll, die chromosomale Integration zu überprüfen. Deshalb wurde mittels PCR und der Primer A141 und B106 die mRNA-Expression der Gensequenz KLF4 und IRES, beide Bestandteile der verwendeten stem cell cassette, untersucht. Die transduzierten Zellinien IMOI1 und VMOI1 wiesen diese Sequenzen auf, ES-7 dementsprechend nicht.

Außerdem wurde die Expression der Stammzellmarker Oct4, Sox2, Nanog und SSEA-1 auf Proteinebene unter Durchführung von immunzytochemischen Färbungen analysiert. Die Transkriptionsfaktoren Oct4, Sox2 und Nanog zeigten positive Signale in den Zellkernen der iPS-Linien IMOI1, VMOI1 und der ES-Linie ES-7. Die Expression des Oct4, Sox2 und Nanog Proteins war in den miPS und den 
mES gleichermassen ausgeprägt, was sich mit den Befunden von Wernig et al. (2007) deckt.

Der Transkriptionsfaktor Sox2 ist ähnlich wie Nanog und Oct4 für die Aufrechterhaltung der Selbsterneuerung von undifferenzierten ES essentiell. Vermutlich wird die Expression von Oct4 durch Sox2 kontrolliert (Masui et al. 2007). Seine Bedeutung innerhalb der vier Reprogrammierungsfaktoren wurde von Avilion et al. (2003) beschrieben.

SSEA-1 ist ein Marker für murine pluripotente Stammzellen, wo er eine wichtige Rolle bei der Adhäsion und Migration von Zellen im präimplantierten Embryo spielt (Solter \& Knowles 1978). Ähnlich wie die alkalische Phosphatase wird auch dieses Protein an der Zellmembran exprimiert.

Der positive Nachweis der Pluripotenz Marker Oct4 und Nanog aus der RT-PCRAnalyse wurde somit auf Proteinebene bestätigt. Zusätzlich wurde die Expression der Marker Sox2 und SSEA-1 mittels Immunfluoreszenz und damit die Pluripotenz der Zellen nachgewiesen.

\subsubsection{DNA-Methylierung}

Alle Reprogrammierungsansätze scheinen mit Modifikationen des Epigenoms einherzugehen. Aus diesem Grunde mussten in dieser Arbeit auch durch die Reprogrammierung ausgelöste epigenetische Veränderungen im Sinne von DNA Methylierungen im genomischen Locus des Gens Oct4 untersucht werden. Es zeigte sich, dass die Promotorregion von Oct4 in den MEFs $\left(\mathrm{la}^{*}, \mathrm{~V} 1^{*}\right)$ nur zu einem geringen Teil unmethyliert vorlag. Im Gegensatz hierzu hatte eine DNA Methylierung von Cytidin-Basen in Cytosin-Guanosin-Nukleotid-Dimeren (CTG) in der Promotorregion des Oct4-Gens der iPS weitgehend nicht stattgefunden. Maherali et al. (2007) zeigten in aus MEFs generierten iPS ein ähnliches Methylierungsmuster in den Pluripotenzgenen Oct4 und Nanog wie in mES. Auch nach der Fusion humaner ES mit humanen Fibroblasten konnte anhand der DNA Methylierung am Oct4 Promotor in den Hybridzellen die Reprogrammierung in ein embryonales Stadium gezeigt werden (Cowan et al. 2005). Eine partielle DNA Demethylierung in begrenzten Arealen der regulatorischen Region von Oct4 wurde auch anderweitig berichtet (Tada et al. 1997; Simonsson \& Gurdon 2004; Takahashi \& Yamanaka 
2006) und ist vermutlich Voraussetzung für die Aktivierung des Gens (Simonsson \& Gurdon 2004). Somit konnte auch auf epigenetischer Ebene eine erfolgreiche Reprogrammierung gezeigt werden.

\subsubsection{In-vitro-Differenzierungspotenzial}

Das Differenzierungspotenzial der generierten Zellen ist eine weitere wesentliche Voraussetzung für die Pluripotenz und eine erfolgreiche Reprogrammierung. Das Differenzierungspotenzial der generierten miPS bzw. mES wurde durch In-vitroDifferenzierung mittels hanging drop-Methode überprüft. Doetschman et al. (1985) beobachteten als erste, dass in Suspensionskultur gehaltene mES unter günstigen Differenzierungsbedingungen spontan Zellaggregate, die EBs, bilden, was später von Thomson et al. (1998) bestätigt wurde.

EBs sind kugelförmige, multizelluläre Strukturen. Die Bildung dieser EBs ist Voraussetzung für eine In-vitro-Differenzierung. Von Zufallsereignissen innerhalb der EBs sind „Entwicklungshinweise" während einer normalen Embryogenese abhängig. Diese Form der Aggregatbildung ist für eine In-vitro-Differenzierung erforderlich und stochastische Vorgänge innerhalb der EBs führen letztendlich zu einer Abfolge von Entwicklungsschritten, wie sie ebenfalls bei der In-vivo-Embryogenese erfolgen (Wei et al. 2005). So entstehen während der Differenzierung innerhalb der EBs zelluläre Bestandteile, die denen der primären Keimblätter (endodermal, ektodermal. mesodermal) ähneln (Wobus \& Boheler 2005).

Die Zellkolonien erschienen vor Beginn der Differenzierung mittels hanging dropMethode als ovale Zellverbände mit im Lichtmikroskop hell erscheinendem Rand. Es konnten keine signifikanten morphologischen Unterschiede zwischen den einzelnen Zellinien festgestellt werden. Die EBs stellten sich an Tag $5+5$ in ihrer charakteristischen „Kopfsteinpflasterstruktur" dar. Auch zu diesem Zeitpunkt erschienen die EBs der iPS und ES morphologisch sehr ähnlich. An Tag 5+15 konnte ein um den ursprünglichen EB formierter Zellverband mit heterogener Zelldichte dokumentiert werden. Nach Boheler et al. (2002) bilden sich Kardiomyozyten innerhalb der EBs zwischen einer äußeren Epithelschicht mit den Charakteristika eines viszeralen Endoderms und einer Basalschicht mesenchymaler Zellen. Die Morphologie der EBs der Zelllinien IMOI1, VMOI1 und ES-7 unterschieden sich an Tag 5+15 in der Mehrzahl der Versuche nicht. Es fiel jedoch auf, dass die EBs der 
iPS-Linie VMOI1 bei einigen Versuchen zu diesem Zeitpunkt eine ähnliche Morphologie wie bereits zum Zeitpunkt Tag 5+5 aufwiesen und ein vermindertes Ausbreiten des peripheren Zellverbandes zeigten.

Im Anschluss an die Differenzierungsversuche wurden die Zellen auf die Genexpression Keimblatt-spezifischer Marker zu drei verschiedenen Zeitpunkten untersucht. Die mesodermale Differenzierung konnte durch Expression des kardialspezifischen Markers $\alpha-M h c$ bestätigt werden. Die $\alpha$-Mhc Expression konnte für IMOI1, VMOI1 und ES-7 ausschließlich an Tag 5+15 gezeigt werden. Es gibt verschiedene MHC Isoformen, die von der Mhc-Gen-Familie codiert werden. Davon sind nur die $\alpha$ - und die $\beta$-Mhc Formen in Herzmuskelzellen exprimiert (Izumo et al. 1986; Lyons et al. 1990). Somit ist die Expression des Mhc-Gens hauptsächlich auf Kardiomyozyten beschränkt.

Die Expression des Hepatozyten spezifischen Markers Afp (Becker et al. 1977) in den iPS und ES-7 sprach für endodermale Differenzierung. Afp war ebenfalls bei allen drei untersuchten Zellinien erst an Tag 5+15 exprimiert, bei VMOI 1 etwas schwächer als bei IMOI1 und ES-7.

Die Expression des neuronalen Transkriptionsfaktors Mash1/Ascl1 (Lo et al. 1991) sprach für eine ektodermale Differenzierungsfähigkeit. Die Ableitung ergibt sich aus der Entwicklung des Neurons aus der neuralen Stammzelle, die sich wiederum aus der Neuralleiste bzw. Ektoderm entwickelt. Mash1 konnte bei den Zelllinien IMOI1 und ES-7 zu den Zeitpunkten Tag 5 und Tag 5+15 nachgewiesen werden, bei der iPS-Linie VMOI1 zeigte sich eine Expression ausschließlich an Tag 5.

\subsection{Analyse der Zellproliferation}

Die Proliferation der miPS IMOI1 und VMOI1 sowie der mES ES-7 wurde durch eine Zellzählung zu drei verschieden Zeitpunkten (Tag 1, Tag 2, Tag 3) ermittelt.

Die Analyse zeigte, dass die Proliferationsrate der miPS verglichen mit den mES zu Beginn geringer war, im Verlauf jedoch zunahm, und es bezüglich der VMOI1 zu keinem signifikanten Unterschied zu den ES-7 an Tag 3 kam. Die Werte der Zellproliferation und Zellzahl der IMOI1 waren deutlich geringer.

Die Untersuchungen deuten darauf hin, dass die mES ES-7 an den ersten beiden Tagen eine stärkere Proliferation als die miPS-Linien aufweisen. Am dritten Tag zeigt 
sich dieser Unterschied zumindest im Vergleich mit VMOI1 nicht mehr, die iPS besitzen sogar eine etwas höhere Zellzahl. Auch andere Arbeiten konnten zeigen, dass sich die Proliferationsraten zwischen mES und miPS nicht unterscheiden (Sridharan et al. 2009). Was die miPS IMOI1 betrifft, so zeigten diese zwar in der Proliferationsanalyse ein signifikant geringeres Wachstum im Vergleich zu VMOI1 und ES-7, dieser Unterschied zeigte sich aber nicht bzgl. der Differenzierungsfähigkeit (siehe 4.2). Warum sich die beiden miPS am Tag 3 in ihrer Proliferationskapazität so deutlich unterscheiden, bleibt weiteren Untersuchungen vorbehalten. Ob möglicherweise Faktoren, die die Proliferationsrate verringern, von IMOI1 gebildet werden und damit der deutliche Unterschied zu der Proliferationsrate der VMOI1 am Tag 3 erklärt werden könnte, bleibt zu untersuchen. Auch könnten umgekehrt Faktoren in den VMOI1 deren Wachstum von Tag 2 zu Tag $3 \mathrm{im}$ Gegensatz zu den IMOI1 stimulieren.

Die Verdopplungszeit ermittelt aus der halb-logarithmischen (In) Darstellung der Wachstumskurven betrug für die IMOI1 119,6 std, für die VMOI1 34,1 std und für die ES-7 41,5 std. Die Verdopplungszeiten von VMOI1 und ES-7 unterscheiden sich nicht sehr stark, nur die Verdopplungszeit von IMOI1 ist deutlich länger. Vergleicht man die Ergebnisse mit den Untersuchungen von Takahashi \& Yamanaka, so fällt auf, dass die Verdopplungszeiten von mES und miPS ähnlich wie bei VMOI1 und ES-7 vergleichbar waren. Insgesamt sind die Verdopplungszeiten mit Werten zwischen 17,0 und 19,4 std jedoch deutlich geringer (Takahashi \& Yamanaka 2006). Die Verdopplungszeiten von Sridharan et al. lagen mit 13 std sogar noch darunter; unabhängig davon unterschieden sie sich jedoch ebenfalls nicht zwischen mES und miPS (Sridharan et al. 2009).

\subsection{Karyotypisierung der kultivierten miPS und mES}

Die Analyse des Karyotyps der generierten miPS im Vergleich zu den mES ermöglicht eine wichtige Aussage darüber, inwiefern die Zelllinien überhaupt therapeutisch nutzbar sind. Die genomische Integrität ist von immenser Bedeutung bei der Herstellung von hoch-qualitativen iPS. Dies ist vor allem von Relevanz in Hinblick auf einen therapeutischen Nutzen, weil genomische Veränderungen zum Beispiel zu Tumorerkrankungen führen können (Amabile \& Meissner 2009). Die Karyotypen von murinen und humanen iPS wurden bereits von zahlreichen Gruppen 
untersucht (Wernig et al. 2007; Takahashi et al. 2007; Yu et al. 2007). Es wurden bei vereinzelten Zelllinien Anomalien festgestellt, der Großteil der Untersuchungen zeigte jedoch einen physiologischen Karyotyp (Amabile \& Meissner 2009). Bezüglich humaner iPS ergaben Untersuchungen wiederum, dass eine Langzeitkultivierung und regelmäßiges Passagieren zu chromosomalen Anomalien führen können (Aasen et al. 2008).

Die Karyotypisierung wurde mit den miPS-Linien IMOI1 und VMOI1 und der mESLinie ES-7 mit Passagen $>20$ durchgeführt. Nach Durchführung des oben genannten Protokolls konnten zahlreiche Zellen mit Metaphase-Chromosomen gezählt werden. Es konnten für alle drei Zelllinien die Chromosomen von knapp 30 Zellen analysiert werden. Die Morphologie der Zelllinien IMOI1, VMOI1 und ES-7 zeigte lichtmikroskopisch keine Unterschiede. Beim Auszählen der Chromosomen zeigte sich, dass die IMOI1 Zellen 25 mal mit 40, XY einen physiologischen Karyotyp aufwiesen, 2 Zellen zeigten den Karyotyp 43, XY. Bei den iPS VMOI1 zeigte sich 29 mal ein physiologischer Karyotyp, außerdem einmal 25, XY. Die mES-Zelllinie ES-7 besaß 25 mal den Karyotyp 40, XY und einmal den pathologischen Karyotyp 53, XY. Arbeiten aus anderen Arbeitsgruppen konnten ebenfalls zeigen, dass generierte iPS größtenteils einen physiologischen Karyotyp aufwiesen, es jedoch auch vereinzelt Aberrationen gab (Takahashi \& Yamanaka 2006). 2010 untersuchten Minina et al. in vitro kultivierte mES und miPS auf chromosomale Instabilitäten. Hierbei zeigte sich in allen mES- und miPS-Linien eine Monosomie X. Des Weiteren konnten auch Trisomien bei der Generierung von iPS gezeigt werden (Sommer et al. 2010, BenDavid \& Benvenisty 2012). Sommer et al. zeigten 2010 wiederholt eine Trisomie von Chromosom 8 und Ben-David \& Benvenisty 2012 zusätzlich eine Trisomie von Chromosom 11. Sowohl Monosomie als auch Trisomien konnte jedoch bei den Zellinien IMOI1, VMOI1 und ES-7 nicht beobachtet werden. Durch eine sehr hohe Zelldichte kam es vor, dass die Chromosomen mehrerer benachbarter Zellen nicht mehr voneinander zu unterscheiden waren, somit die Chromosomenzählung teilweise erschwert war und das Ergebnis beeinflusst wurde. Es ist somit wahrscheinlich, dass die wenigen Abweichungen der Chromosomenzahl hierdurch zustande kamen. Außerdem lässt sich sagen, dass sowohl die Morphologie als auch die Chromosomenzahl der analysierten Zelllinien nur geringe Unterschiede im Vergleich aufwiesen und als physiologisch anzusehen sind. 
Nichtsdestotrotz muss jedoch erwähnt werden, dass die in dieser Arbeit durchgeführte Chromosomenanalyse sehr stark Untersucher-abhängig ist und es sicherlich verlässlichere Verfahren zum Nachweis genomischer Integration gibt. Neuere Verfahren wie beispielsweise Fluoreszenz in situ Hybridisierung (FISH), spektrale Karyotypisierung (SKY) und multiplex fluorescence in situ hybridization (MFISH) stellen hier sicherlich bessere Verfahren zur Chromosomenanalyse dar. Vor allem SKY und M-FISH ermöglichen den Nachweis diskreter Translokationen und komplexer Pathologien (Schröck et al. 1997; Speicher et al. 1996).

\subsection{Kardiale Differenzierung muriner iPS und ES und deren Charakterisierung}

In dieser Arbeit konnte gezeigt werden, dass eine kardiale Differenzierung der miPS IMOI1, VMOI1 und der mES ES-7 möglich war.

Die RT-PCR zeigte, dass die frühen kardialen Marker Gata4 und Nkx2.5 bei je einem Versuch von IMOI1 und ES-7 exprimiert wurden. Auch die Zelllinie VMOI1 zeigte eine schwache Expression. Die Expression kardialer Marker wurde ebenfalls auf Protein-Ebene bestätigt, hierzu wurde eine a-Aktinin-Immunfluoreszenzfärbung durchgeführt.

1985 beobachteten Doetschman und Kollegen erstmals, dass in einer Differenzierungs-freundlichen Lösung kultivierte mES sog. EBs bilden. Aus murinen ES-Zellen generierte Kardiomyozyten zeigen eine große Vielfalt und typische Charakteristika des primitiven Herzens bzw. des frühen Myokards (Fijnvandraat et al. 2003). Mittels RT-PCR-Analysen wurden kardiale Transkriptionsfaktoren wie Gata4 und Nkx2.5, spezifische kardiale Gene wie Troponin $T$ und $I$, als auch Anf und ventrikuläres Mlc (myosin light chain) nachgewiesen (Wei et al. 2005). Neben den Kardiomyozyten-spezifischen Genen wurde außerdem die Morphologie der differenzierten Zellen von zahlreichen Gruppen untersucht. Hierbei fiel auf, dass sich die Myofibrillen in frühen Stadien noch spärlich und ungeordnet darstellen. Mit zunehmender Ausreifung zeigen sie jedoch eine myofibrilläre und Sarkomer-typische Organisation (Boheler et al. 2002).

Dass eine Expression von Gata4 und Nkx2.5 gleichermaßen nicht in allen Zellen bzw. nicht in allen Versuchen nachzuweisen war, kann möglicherweise mit der Tatsache, dass beide Marker miteinander interagieren bzw. als gemeinsame 
Kofaktoren gelten (Durocher et al. 1997), erklärt werden. Die späten kardialen Marker $\alpha-M h c, M l c 2 v$ und Anf wurden bei allen Versuchen der drei Zellinien exprimiert (siehe Abb. 15). ES-abgeleitete Kardiomyozyten exprimieren $\alpha$-Mhc und $\beta$ Mhc (Sanchez et al. 1991). Die $\alpha$-Mhc Expression reflektiert eine fortschreitende weitere Maturation der Kardiomyozyten (Kouskoff et al. 2005). Auch von humanen ES abgeleitete Kardiomyozyten exprimieren GATA4, myocyte enhancer factor-2 (MEF-2), NKX2.5, MHC, MLC2V und ANF (Kehat et al. 2001; Xu et al. 2002).

Die Expression kardialer Marker wurde ebenfalls auf Protein-Ebene analysiert. Hierzu wurde eine a-Aktinin-Immunfluoreszenzfärbung mit den Zelllinien IMOI1, VMOI1 und ES-7 an Tag 22 der Differenzierung durchgeführt. Es bestätigte sich, dass die aus IMOI1, VMOI1 und ES-7 differenzierten Kardiomyozyten a-Aktinin exprimieren. Des Weiteren konnte eine physiologische Morphologie mit mittelständigen Zellkernen und Herzmuskel-spezifische Querstreifung gezeigt werden (siehe Abb. 16a-c). Diese wurde 1985 bei aus mES differenzierten Kardiomyozyten erstmals von Doetschman et al. beschrieben (Doetschman et al. 1985). 2008 zeigten Schenke-Layland et al. aus miPS differenzierte Zellcluster, die ebenfalls nach Immunfluoreszenzfärbung eine für Kardiomyozyten charakteristische Querstreifung aufwiesen (Schenke-Layland et al. 2008). Diese Ergebnisse decken sich mit den in dieser Arbeit generierten und lassen darauf schließen, dass die aus IMOI1, VMOI1 und ES-7 differenzierten Kardiomyozyten einen physiologischen Phänotyp aufweisen.

Die optische Betrachtung der sich differenzierenden Zellen zeigte zwischen den Zelllinien IMOI1 und ES-7 keine auffälligen Unterschiede, was auch die Analyse der kardialen Marker und die Immunfluoreszenzfärbung bestätigte. Die Differenzierung der iPS-Linie VMOI1 erschien rein optisch verlangsamt, und es zeigten sich deutlich weniger schlagende Kardiomyozytenareale.

Die quantitative Analyse der differenzierten Kardiomyozyten erfolgte anhand einer Durchflusszytometrie für die Zellen IMOI1, VMOI1 und ES-7 zu drei verschiedenen Zeitpunkten (Tag 10, 15, 22) in jeweils 4 Versuchen $(n=4)$. Mit Hilfe der FLOWAnalyse konnte der relative Anteil der eGfp-positiven Zellen in Bezug zu der betrachteten Gesamt-Zellzahl gesetzt werden.

Die Kardiomyozyten-Differenzierung der iPS setzte später ein als die der ES. Zum Zeitpunkt Tag 22 unterschieden sich die mES und die IMOI1 jedoch nicht mehr. 
Auffällig war das Verhalten der VMOI1 Zellen: Der Anteil eGfp-positiver Zellen war deutlich höher als bei den beiden anderen Zelllinien. Dieser Unterschied war jedoch statistisch nicht signifikant. Obwohl die Gewinnung sowohl der IMOI1 als auch der VMOI1 nach gleichem Protokoll erfolgte, nur die Ausgangs-Fibroblasten von unterschiedlichen Mäusen stammten, lassen die Ergebnisse auf eine deutliche, wenn auch partielle biologische Variabilität schließen. Diese dürfte weitgehend mit dem Handling der Zellkulturen (Ernten, Passagieren usw.) in Verbindung stehen. Auffällig sind jedoch die relativ hohen Werte der Standardabweichungen. Diese sprechen für eine hohe Variabilität in der Ausbeute der einzelnen Versuche.

Auch Mauritz et al. untersuchten 2008 den Anteil ihrer kardiomyzytären Differenzierung aus mES bzw. miPS anhand der Troponin T Expression mittels realtime RT-PCR. Hierbei fiel auf, dass bei den aus miPS differenzierten Zellen an Tag 10 und Tag 21 die Troponin $\mathrm{t}$ Expression unter $1 \%$ lag, bei den aus $\mathrm{mES}$ differenzierten Zellen lag sie zwischen 1,5 und 2\% (Mauritz et al. 2008).

Es fällt auf, dass sich der Anteil der Kardiomyozyten an Tag 10 von denen in dieser Arbeit generierten Daten unwesentlich unterscheidet. Vergleicht man jedoch den kardiomyozytären Anteil an Tag 21 bzw. 22, so ist dieser bei den ES-7 mehr als doppelt so hoch und bei den IMOI1 bzw. VMOI1 mehr als fünfmal so hoch im Vergleich zu den Daten von Mauritz et al. Es fällt außerdem auf, dass bei Mauritz et al. die differenzierten mES ein höheres kardiomyozytäres Outcome hatten, wohingegen in dieser Arbeit das Outcome der differenzierten miPS höher war. Es ist jedoch anzunehmen, dass dieser Aspekt eher von der jeweiligen Zelllinie und der Qualität der Differenzierung abhängt als von der Tatsache ob mES oder miPS vorliegen.

\subsection{Aufreinigung der aus murinen iPS und ES differenzierten Kardiomyozyten}

In Hinblick auf eine mögliche Transplantation der charakterisierten Zellen in physiologisches aber auch pathologisches Herzmuskelgewebe ist die Aufreinigung der differenzierten Herzmuskelzellen ein essentieller Schritt. Diverse Arbeiten konnten zeigen, dass eine mangelnde Aufreinigung und anschließende Transplantation von undifferenzierten Zellen zu einer Teratombildung führen kann (Brüstle et al. 1997; Deacon et al. 1998; Hentze et al. 2006). 
Analyse und Aufreinigung der Zellen erfordern ihre Markierung. Hierbei können beispielsweise verschiedene intrazelluläre Fluoreszenzfarbstoffe bei der Visualisierung mittels Fluoreszenzmikroskopie oder aber auch bei der Auftrennung der Zellen durch FACS hilfreich sein (Giudice \& Trounson 2008). Ferner kann, wenn die Zellen über eine Antibiotikaresistenz verfügen, eine Antibiotika-Selektion vorgenommen werden.

In dieser Arbeit wurden sowohl der Fluoreszenzfarbstoff eGfp als auch eine Neomycin Resistenz in die Kardiomyozyten mit Hilfe eines Mhc-Neo/Mhc-eGfpKonstruktes eingebracht. Durch den Promotor $\alpha$-Mhc wird das eGfp exprimiert als eine wichtige Voraussetzung, die differenzierten Kardiomyozyten in vivo nach Transplantation nachverfolgen zu können (Rubart et al. 2003).

Auch verhilft der murine und herzspezifische $\alpha$-Mhc Promotor den differenzierten Kardiomyozyten zu dieser Resistenz (Neomycin/Geneticin) durch verstärkte Expression des Resistenzgens (Gulick et al. 1991). Die analysierten Zellen wurden aus doppelt transgenen Mäusen (Mhc-Neo/Mhc-eGfp) gewonnen; da sie die genannten Transgene enthielten, war das Einbringen der einzelnen Gene beispielsweise durch Transfektion nicht erforderlich.

Es zeigte sich, dass zum Zeitpunkt Tag 22 nahezu ausschließlich kontraktile Kardiomyozyten nach Antibiokaselektion auf den Zellkulturschalen bzw. chamber slides zu finden waren. Diese wiesen in der Fluoreszenzmikroskopie die grüne Farbe des eGfp's auf. Wir konnten damit Ergebnisse reproduzieren, die eine andere Arbeitsgruppe für die Bildung stabiler humaner ES mit exprimiertem eGfp, getrieben durch den $\alpha$-Mhc Promotor, beschrieben hatte (Kita-Matsuo et al. 2009).

Die Selektion der Kardiomyozyten durch das Antiobiotikum G418 konnte bei den Invitro-Versuchen erfolgreich durchgeführt werden. Eine solche positive Selektion durch Antibiotika nach Aktivierung des Neomycin Resistenzgens durch den herzspezifischen Maus $\alpha$-Mhc Promotor zur Generierung humaner ES wurde von Xu et al. (2008) beschrieben.

Abb. 16a-c zeigt die sowohl eGfp- als auch a-Aktinin-positven differenzierten Kardiomyozyten.

Während die Differenzierungsversuche für die Durchflusszytometrie ohne eine Antibiotikaselektion erfolgten, wurde zusätzlich der Anteil eGfp-positiver Kardiomyozyten nach Antibiotikaselektion zum Zeitpunkt Tag 22 bestimmt. Dies erfolgte über ein Auszählen von DAPI-positiven bzw. DAPI-a-Aktinin-positiven 
(doppelt-positiven) Zellen nach Immunfluoreszenzfärbung. Diese Analyse zeigte, dass der Anteil doppelt-positiver Zellen bei ES-7 bei 84,1\% lag. Bei den miPS betrug der Anteil doppelt-positiver Zellen bei IMOI1 79,4\% und bei VMOI1 81,4\%. Vergleicht man die Daten beispielsweise mit denen von Tao et al., fält auf, dass der eGfppositive Anteil nach G418-Selektion bei über $90 \%$ liegt (Tao et al. 2015). Anhand der analysierten Daten ist anzunehmen, dass es je nach verwendeter Zelllinie Differenzen im kardialen Outcome gibt. Des Weiteren sind die Ergebnisse sehr stark von der Art der Untersuchung abhänging. Bei der in dieser Arbeit durchgeführten Zellzählung wurden die immunhistochemisch gefärbten Zellen auf sog. chamber slides gefärbt und gezählt. Um ein Anheften der kontrahierenden Kardiomyozyten gewährleisten zu können, mussten diese im Vorfeld mit MEFs beschichtet werden. Es ist also davon auszugehen, dass der Großteil der DAPI-positiven jedoch aAktinin-negativen Zellen durch die MEF-Beschichtung zustande kommt. Um eine solche Verunreinigung und damit verbundene Ungenauigkeit zu vermeiden, könnte man beispielsweise die oben genannte FACS-Analyse (statt der durchgeführten Zellzählung) bei den selektierten eGfp-positiven Kardiomyozyten durchführen.

Die aufgereinigten Kardiomyozyten der Zelllinien ES-7 wurden des Weiteren in immundefiziente RAG-N- bzw. RAG-C-Mäuse intrakardial injiziert. Nach acht Wochen wurden die Herzen entnommen und histologisch untersucht. Es konnten jedoch keine verwertbaren Daten gewonnen werden, da sich keine injizierten (eGfppositiven) Zellen finden ließen. Ein Grund hierfür könnte der Zeitpunkt der Entnahme der Herzen sein. Klug et al. beschrieben 1996, dass sie ihre gernerierten Kardiomyozyten nur bis zu sieben Wochen nach Implantation finden konnten. Bei der Injektion wurden je nach quantitativem Outcome des Versuchs 60-100.000 Zellen injiziert. Es ist möglich, dass diese Menge zu gering war oder auch ein Großteil der transplantierten Zellen durch Fehlinjektion über Gefäße ausgeschwämmt wurde. Weitere Studien mit FLK1 positiven Zellen gehen davon aus, dass der ebenfalls verwendete Fluoreszenzfarbstoff eGfp bei einer starken Autofluoreszenz der injizierten Herzen schlecht nachweisbar ist (unveröffentlichte Daten). Zaruba et al. konnten diese Annahme 2010 jedoch widerlegen, indem sie 10 bis 21 Tage nach Injektion eGfp-positive Zellen nachweisen konnten.

Weitere Untersuchungen müssen zeigen, ob die in dieser Arbeit generierten Zelllinien für eine Transplantation geeignet sind. 


\subsection{Schlussfolgerung und Ausblick}

Die In-vitro-Untersuchungen dieser Arbeit konnten zeigen, dass die vorliegenden murinen iPS ähnliche Charakteristika aufweisen, wie die analysierte mES-Linie. Die Reprogrammierung mit Hilfe von vier Transkriptionsfaktoren in einer einzigen lentiviralen stem cell cassette war somit erfolgreich.

Beim Nachweis der Pluripotenz zeigten sowohl ES als auch iPS keinerlei Unterschiede. Dies konnte auf mRNA- und Protein-Ebene gezeigt werden. Auch die Morphologie der Zellen während der Differenzierung in Zellen der drei Keimblätter wies nur geringe Unterschiede auf. Ob eine schwächere bzw. teils fehlende Expression Keimblatt-spezifischer Marker speziell bei den VMOI1-Zellen auf eine schlechtere Differenzierung hindeutet, lässt sich nicht mit Bestimmtheit sagen, zumal weitere Untersuchungen wie z.B. Karyotypisierung und auch die anschließende Differenzierung in Kardiomyozyten keine Unterschiede zwischen den eingesetzten Zellen erkennen ließen. Die Kardiomyogenese in kultivierten embryonalen und in den induziert pluripotenten Stammzellen war ebenfalls erfolgreich und stellt sich als ein gut reproduzierbares Geschehen dar. Die Markierung der Kardiomyozyten mit Hilfe des eGfp und ihre Neomycin-Resistenz erlaubt sowohl eine Trennung der Kardiomyozyten von nicht differenzierten Zellen als auch die Überprüfung der Lokalisation der Kardiomyozyten nach etwaigen Transplantationen.

Naheliegend ist es daher, in einer weiteren Forschungsarbeit die in dieser Arbeit erzeugten und markierten Kardiomyozyten Mäusen nach Myokardinfarkt zu implantieren und zu prüfen, ob die Zellen nach Transplantation überleben und ihre funktionale Rolle in vivo übernehmen können. 


\section{Zusammenfassung}

Die vorgelegte Arbeit ist im Zusammenhang mit den vielfältigen Forschungsaktivitäten zu sehen, eine geeignete Zellersatztherapie bei strukturellen Myokarderkrankungen zu finden und ggf. zu etablieren. Induziert pluripotente Stammzellen, die sich weitestgehend nicht von ES unterscheiden und sich in Kardiomyozyten differenzieren lassen, stellen hierbei eine prinzipielle Möglichkeit dar.

Die Aufgabe bestand darin, miPS im Vergleich zu ES zu charakterisieren, sie in Kardiomyozyten zu differenzieren und diese zu charakterisieren. Darüber hinaus sollte eine Antibiotikaselektion der Kardiomyozyten und ihre Aufreinigung mittels eines Fluoreszenzfarbstoffes erreicht werden.

Die In-vitro-Untersuchungen zeigten eine erfolgreiche Reprogrammierung mit Hilfe der vier Transkriptionsfaktoren OCT4, SOX2, KLF4 und $c-M Y C$ in einer einzigen lentiviralen stem cell cassette und außerdem, dass die vorliegenden miPS ähnliche Charakteristika aufwiesen wie die verwendeten ES.

Beim Nachweis der Pluripotenz zeigten sowohl die embryonalen als auch die induzierten pluripotenten Stammzellen auf mRNA- und Protein-Ebene keinerlei Unterschiede. Auch die Morphologie der Zellen während der Differenzierung in Zellen der drei Keimblätter wies nur geringe Unterschiede auf. Darüber hinaus zeigten die einzelnen Zelllinien auch nach längerer Kultivierung einen normalen Karyotyp.

Unter Verwendung eines standardisierten EB basierten Differenzierungsprotokolls (hanging drop-Methode) für ES wurden die induziert pluripotenten und embryonalen Stammzellen über 22 Tage in Kardiomyozyten differenziert. Als Quelle der verwendeten Zelllinien wurden doppelt-transgene Mäuse (Mhc-Neo/Mhc-eGfp) eingesetzt. Damit gelang die Mhc-abhängige Expression von eGfp und Neomycinresistenz in den Kardiomyozyten, wodurch das Visualieren und die Selektion von intakten Herzmuskelzellen ermöglicht wurden.

Analysen auf molekularer, struktureller und funktionaler Ebene zeigten in den zu Kardiomyozyten differenzierten iPS typische Merkmale von ES-abgeleiteten Kardiomyozyten. Analysen mit der reversen Transkriptions-PCR zeigten die Expression der für das Mesoderm und die Kardiomyozyten typischen Markergene wie Gata4, Nkx2.5, $\alpha-M h c, M l c 2 v$ und Anf. Auch auf Proteinebene konnte die 
Expression kardialer Marker bestätigt werden.

Somit konnte die Differenzierung von induziert pluripotenten Stammzellen in funktionale Kardiomyozyten gezeigt werden.

Mit der Verwendung von aus induziert pluripotenten Stammzellen gewonnenen Kardiomyozyten können im Gegensatz zur Verwendung embryonaler Stammzellen Probleme wie die immunologische Abstoßungsreaktion und die Embryonenverbrauchende Forschung als ethischer Konflikt umgangen werden.

Basierend auf den in dieser Arbeit erzielten Ergebnissen müssen in einer weiteren Forschungsarbeit die erzeugten und markierten Kardiomyozyten Mäusen implantiert werden; ferner ist zu prüfen, ob die Zellen nach Transplantation überleben und ihre funktionale Rolle in vivo übernehmen können. Des Weiteren müssen für einen therapeutischen Einsatz beim Menschen die vorliegenden Ergebnisse mit humanen Zellen reproduziert werden. 


\section{Literaturverzeichnis}

Aasen T, Raya A, Barrero MJ, Garreta E, Consiglio A, Gonzalez F, Vassena R, Bilić J, Pekarik V, Tiscornia G, Edel M, Boué S, Izpisúa Belmonte JC (2008): Efficient and rapid generation of induced pluripotent stem cells from human keratinocytes. Nat Biotechnol 26(11), 1276-1284.

Amabile G, Meissner A (2009): Induced pluripotent stem cells: current progress and potential for regenerative medicine. Trends Mol Med 15(2), 59-68.

Anokye-Danso F, Trivedi CM, Juhr D, Gupta M, Cui Z, Tian Y, Zhang Y, Yang W, Gruber PJ, Epstein JA, Morrisey EE (2011): Highly efficient miRNA-mediated reprogramming of mouse and human somatic cells to pluripotency. Cell Stem Cell $\underline{8}$, 376-388.

Avilion AA, Nicolis SK, Pevny LH, Perez L, Vivian N, Lovell-Badge R (2003): Multipotent cell lineages in early mouse development depend on SOX2 function. Genes Dev 17, 126-140.

Balsam LB, Wagers AJ, Christensen JL, Kofidis T, Weissman IL, Robbins RC (2004): Haematopoietic stem cells adopt mature haematopoietic fates in ischaemic myocardium. Nature 428(6983), 668-673.

Bardy GH, Lee KL, Mark DB, Poole JE, Packer DL, Boineau R, Domanski M, Troutman C, Anderson J, Johnson G, McNulty SE, Clapp-Channing N, Davidson-Ray LD, Fraulo ES, Fishbein DP, Luceri RM, Ip JH; Sudden Cardiac Death in Heart Failure Trial (SCD-HeFT) Investigators (2005): Amiodarone or an implantable cardioverter-defibrillator for congestive heart failure. N Engl J Med 352(3), 225-237.

Becker FF, Stillman D, Sell S (1977): Serum a-fetoprotein in a mouse strain (C3HAvy fB) with spontaneous hepatocellular carcinomas. Cancer Res 37, 870-872.

Bellin M, Marchetto MC, Gage FH, Mummery CL (2012): Induced pluripotent stem cells: the new patient? Nat Rev Mol Cell Biol doi: 10.1038/nrm3448.

Beltrami AP, Barlucchi L, Torella D, Baker M, Limana F, Chimenti S, Kasahara H, Rota M, Musso E, Urbanek K, Leri A, Kajstura J, Nadal-Ginard B, Anversa P (2003): Adult cardiac stem cells are multipotent and support myocardial regeneration. Cell 114(6), 763-776.

Ben-David U, Benvenisty N (2012): High prevalence of evolutionarily conserved and species-specific genomic aberrations in mouse pluripotent stem cells. Stem Cells 30(4), 612-622.

Ben-Shushan E, Thompson JR, Gudas LJ, Bergman Y (1998): Rex-1, a gene encoding a transcription factor expressed in early embryo, is regulated via Oct-3/4 and Oct- 6 binding to an octamer site and a novel protein, Rox-1, binding to an adjacent site. Mol Cell Biol 18, 1866-1878. 
Bleasdale RA, Frenneaux MP (2004): Cardiac resynchronisation therapy: when the drugs don't work. Heart 90, 2-4.

Bleumink GS, Knetsch AM, Sturkenboom MC, Straus SM, Hofman A, Deckers JW, Witteman JC, Stricker BH (2004): Quantifying the heart failure epidemic: prevalence, incidence rate, lifetime risk and prognosis of heart failure The Rotterdam Study. Eur Heart J 25(18), 1614-1619.

Boheler KR, Czyz J, Tweedie D, Yang HT, Anisimov SV, Wobus AM (2002): Differentiation of pluripotent embryonic stem cells into cardiomyocytes. Circ Res 91(3), 189-201.

Boyer LA, Lee TI, Cole MF, Johnstone SE, Levine SS, Zucker JP, Guenther MG, Kumar RM, Murray HL, Jenner RG, Gifford DK, Melton DA, Jaenisch R, Young RA (2005): Core transcriptional regulatory circuitry in human embryonic stem cells. Cell 122(6), 947-956.

Braunstein JB, Anderson GF, Gerstenblith G, Weller W, Niefeld M, Herbert R, Wu AW (2003): Noncardiac comorbidity increases preventable hospitalizations and mortality among Medicare beneficiaries with chronic heart failure. J Am Coll Cardiol 42(7), 1226-1233.

Brüstle O, Spiro AC, Karram K, Choudhary K, Okabe S, McKay RD (1997): In vitrogenerated neural precursors participate in mammalian brain development. Proc Natl Acad Sci U S A 94(26), 14809-14814.

Burdon T, Chambers I, Stracey C, Niwa H, Smith A (1999): Signaling mechanisms regulating self-renewal and differentiation of pluripotent embryonic stem cells. Cells Tissues Organs 165(3-4), 131-143.

Chambers I, Colby D, Robertson M, Nichols J, Lee S, Tweedie S, Smith A (2003): Functional expression cloning of Nanog, a pluripotency sustaining factor in embryonic stem cells. Cell 113, 643-655.

Chan EM, Ratanasirintrawoot S, Park IH, Manos PD, Loh YH, Huo H, Miller JD, Hartung O, Rho J, Ince TA, Daley GQ, Schlaeger TM (2009): Live cell imaging distinguishes bona fide human iPS cells from partially reprogrammed cells. Nat Biotechnol 27(11), 1033-1037.

Chen X, Xu H, Yuan P, Fang F, Huss M, Vega VB, Wong E, Orlov YL, Zhang W, Jiang J, Loh YH, Yeo HC, Yeo ZX, Narang V, Govindarajan KR, Leong B, Shahab A, Ruan Y, Bourque G, Sung WK, Clarke ND, Wei CL, Ng HH (2008): Integration of external signaling pathways with the core transcriptional network in embryonic stem cells. Cell 133(6), 1106-1117.

Chun YS, Byun K, Lee B (2011): Induced pluripotent stem cells and personalized medicine: current progress and future perspectives. Anat Cell Biol 44, 245-255. 
Cohn JN, Johnson G, Ziesche S, Cobb F, Francis G, Tristani F, Smith R, Dunkman WB, Loeb $\mathrm{H}$, Wong $\mathrm{M}$ et al. (1991): A comparison of enalapril with hydralazineisosorbide dinitrate in the treatment of chronic congestive heart failure. $\mathrm{N} \mathrm{Engl} \mathrm{J}$ Med 325(5), 303-310.

Cohn JN, Bristow MR, Chien KR, Colucci WS, Frazier OH, Leinwand LA, Lorell BH, Moss AJ, Sonnenblick EH, Walsh RA, Mockrin SC, Reinlib L (1997): Report of the National Heart, Lung, and Blood Institute Special Emphasis Panel on Heart Failure Research. Circulation 95(4), 766-770.

[CONSENSUS (No authors listed] (1987): Effects of enalapril on mortality in severe congestive heart failure. Results of the Cooperative North Scandinavian Enalapril Survival Study (CONSENSUS). The CONSENSUS Trial Study Group. N Engl J Med 316(23), 1429-1435

Cowan CA, Atienza J, Melton DA, Eggan K (2005): Nuclear Reprogramming of Somatic Cells After Fusion with Human Embryonic Stem Cells. Science 309, 13691373.

Daubert JC, Pavin D, Jauvert G, Mabo P (2004): Intra- and interatrial conduction delay: implications for cardiac pacing. Pacing Clin Electrophysiol 27(4), 507-525.

Davie AP, Francis CM, Caruana L, Sutherland GR, McMurray JJ (1997): Assessing diagnosis in heart failure: which features are any use? QJM 90(5), 335-339.

Deacon T, Dinsmore J, Costantini LC, Ratliff J, Isacson O (1998): Blastula-stage stem cells can differentiate into dopaminergic and serotonergic neurons after transplantation. Exp Neurol 149(1), 28-41.

Digitalis Investigation Group (1997): The effect of digoxin on mortality and morbidity in patients with heart failure. N Engl J Med 336(8), 525-533.

Dimos JT, Rodolfa KT, Niakan KK, Weisenthal LM, Mitsumoto H, Chung W, Croft GF, Saphier G, Leibel R, Goland R, Wichterle H, Henderson CE, Eggan K (2008): Induced pluripotent stem cells generated from patients with ALS can be differentiated into motor neurons. Science 321(5893), 1218-1221.

Doetschman TC, Eistetter H, Katz M, Schmidt W, Kemler R (1985): The in vitro development of blastocyst-derived embryonic stem cell lines: formation of visceral yolk sac, blood islands and myocardium. J Embryol Exp Morphol 87, 27-45.

Domen J, Weissman IL (1999): Self-renewal, differentiation or death: regulation and manipulation of hematopoietic stem cell fate. Mol Med Today $\underline{5}(5), 201-8$.

Durocher D, Charron F, Warren R, Schwartz RJ, Nemer M (1997): The cardiac transcription factors Nkx2-5 and GATA-4 are mutual cofactors. EMBO J 16(18), 5687-5696.

Ebert AD, Yu J, Rose FF, Mattis VB, Lorson CL, Thomson JA, Svendsen CN (2009): Induced pluripotent stem cells from a spinal muscular atrophy patient. Nature 457 , 277-280. 
Evans MJ, Kaufman MH (1981): Establishment in culture of pluripotential cells from mouse embryos. Nature 292, 154-156.

Faris R, Flather M, Purcell H, Henein M, Poole-Wilson P, Coats A (2002): Current evidence supporting the role of diuretics in heart failure: a meta analysis of randomised controlled trials. Int J Cardiol 82(2), 149-158.

Fijnvandraat AC, van Ginneken AC, Schumacher CA, Boheler KR, Lekanne Deprez $\mathrm{RH}$, Christoffels VM, Moorman AF (2003): Cardiomyocytes purified from differentiated embryonic stem cells exhibit characteristics of early chamber myocardium. J Mol Cell Cardiol 35(12), 1461-1472.

Flather MD, Shibata MC, Coats AJ, Van Veldhuisen DJ, Parkhomenko A, Borbola J, Cohen-Solal A, Dumitrascu D, Ferrari R, Lechat P, Soler-Soler J, Tavazzi L, Spinarova L, Toman J, Böhm M, Anker SD, Thompson SG, Poole-Wilson PA; SENIORS Investigators (2005): Randomized trial to determine the effect of nebivolol on mortality and cardiovascular hospital admission in elderly patients with heart failure (SENIORS). Eur Heart J 26(3), 215-225.

Francis GS (2001): Pathophysiology of chronic heart failure. Am J Med 110, 37-46.

Francis SC, Katovich MJ, Gelband CH, Raizade MK (2001): Gene therapy in cardiovascular disease. Current status. Am J Pharmacogenomics 1(1), 55-66.

Fuegemann CJ, Samraj AK, Walsh S, Fleischmann BK, Jovinge S, Breitbach M (2010): Differentiation of mouse embryonic stem cells into cardiomyocytes via the hanging-drop and mass culture methods. Curr Protoc Stem Cell Biol 2010 Dec;Chapter 1:Unit 1F.11.

Fusaki N, Ban H, Nishiyama A, Saeki K, Hasegawa M (2009): Efficient induction of transgene-free human pluripotent stem cells using a vector based on Sendai virus, an RNA virus that does not integrate into the host genome. Proc Jpn Acad Ser B Phys Biol Sci 85, 348-362.

Giudice A, Trounson A (2008): Genetic modification of human embryonic stem cells for derivation of target cells. Cell Stem Cell 2(5), 422-433.

Gruh I, Beilner J, Blomer U, Schmiedl A, Schmidt-Richter I, Kruse ML, Haverich A, Martin U (2006): No evidence of transdifferentiation of human endothelial progenitor cells into cardiomyocytes after coculture with neonatal rat cardiomyocytes. Ciculation $113,1326-1334$.

Guan K, Hasenfuss G (2007): Do stem cells in the heart truly differentiate into cardiomyocytes? J Mol Cell Cardiol 43(4), 377-387.

Gulick J, Subramaniam A, Neumann J, Robbins J (1991): Isolation and characterization of the mouse cardiac myosin heavy chain genes. J Biol Chem 266(14), 9180-9185. 
Hattori F, Chen H, Yamashita H, Tohyama S, Satoh YS, Yuasa S, Li W, Yamakawa H, Tanaka T, Onitsuka T, Shimoji K, Ohno Y, Egashira T, Kaneda R, Murata M, Hidaka K, Morisaki T, Sasaki E, Suzuki T, Sano M, Makino S, Oikawa S, Fukuda K (2010): Nongenetic method for purifying stem cell-derived cardiomyocytes. Nat Methods $7,61-66$.

Heng JC, Feng B, Han J, Jiang J, Kraus P, Ng JH, Orlov YL, Huss M, Yang L, Lufkin T, Lim B, Ng HH (2010): The nuclear receptor Nr5a2 can replace Oct4 in the reprogramming of murine somatic cells to pluripotent cells. Cell Stem Cell $\underline{6}(2), 167-$ 174.

Hentze H, Graichen R, Colman A (2007): Cell therapy and the safety of embryonic stem cell-derived grafts. Trends Biotechnol 25(1), 24-32.

Hjalmarson A, Fagerberg B (2000): MERIT-HF mortality and morbidity data. Basic Res Cardiol 95,98-103.

Hobbs FD (2002): Unmet need for diagnosis of heart failure: the view from primary care. Heart 88, 9-11.

Holtzer H, Okayama M, Biehl J, Holtzer S (1978): Chondrogenesis in chick limb buds and somites. Experientia 34(3), 281-4.

Hosler BA, LaRosa GJ, Grippo JF, Gudas LJ (1989): Expression of REX-1, a gene containing zinc finger motifs, is rapidly reduced by retinoic acid in F9 teratocarcinoma cells. Mol Cell Biol $\underline{9}(12), 5623-5629$.

Izumo S, Nadal-Ginard B, Mahdavi V (1986): All members of the MHC multigene family respond to thyroid hormone in a highly tissue-specific manner. Science 231(4738), 597-600.

Jackson KA, Majka SM, Wang H, Pocius J, Hartley CJ, Majesky MW, Entman ML, Michael LH, Hirschi KK, Goodell MA (2001): Regeneration of ischemic cardiac muscle and vascular endothelium by adult stem cells. The Journal of Clinical Investigation 107, 1395-1402.

Jiang J, Chan YS, Loh YH, Cai J, Tong GQ, Lim CA, Robson P, Zhong S, Ng HH (2008): A core Klf circuitry regulates self-renewal of embryonic stem cells. Nat Cell Biol 10(3), 353-360.

Kehat I, Kenyagin-Karsenti D, Snir M, Segev H, Amit M, Gepstein A, Livne E, Binah O, Itskovitz-Eldor J, Gepstein L (2001): Human embryonic stem cells can differentiate into myocytes with structural and functional properties of cardiomyocytes. J Clin Invest 108(3), 407-414.

Keirstead HS, Nistor G, Bernal G, Totoiu M, Cloutier F, Sharp K, Steward O (2005): Human embryonic stem cell-derived oligodendrocyte progenitor cell transplants remyelinate and restore locomotion after spinal cord injury. J Neurosci 25(19), 46944705. 
Khunti K, Baker R, Grimshaw G (2000): Diagnosis of patients with chronic heart failure in primary care: usefulness of history, examination, and investigations. $\mathrm{Br} \mathrm{J}$ Gen Pract 50(450), 50-54.

Kim J, Chu J, Shen X, Wang J, Orkin SH (2008): An extended transcriptional network for pluripotency of embryonic stem cells. Cell 132(6), 1049-1061.

Kita-Matsuo H, Barcova M, Prigozhina N, Salomonis N, Wei K, Jacot JG, Nelson B, Spiering S, Haverslag R, Kim C, Talantova M, Bajpai R, Calzolari D, Terskikh A, McCulloch AD, Price JH, Conklin BR, Chen HS, Mercola M (2009): Lentiviral vectors and protocols for creation of stable hESC lines for fluorescent tracking and drug resistance selection of cardiomyocytes. PLoS One 4(4), e5046.

Klug MG, Soonpaa MH, Koh GY, Field LJ (1996): Genetically selcted cardiomyocytes from differentiating embryonic stem cells form stable intracardiac grafts. J Clin Invest 98(1), 216-224.

Kopp JL, Ormsbee BD, Desler M, Rizzino A (2008): Small increases in the level of Sox2 trigger the differentiation of mouse embryonic stem cells. Stem Cells 26(4), 903-911.

Kouskoff V, Lacaud G, Schwantz S, Fehling HJ, Keller G (2005): Sequential development of hematopoietic and cardiac mesoderm during embryonic stem cell differentiation. Proc Natl Acad Sci U S A 102(37), 13170-13175.

Laflamme MA, Murry CE (2005): Regenerating the heart. Nat Biotechnol 23(7), 845856.

Laflamme MA, Chen KY, Naumova AV, Muskheli V, Fugate JA, Dupras SK, Reinecke H, Xu C, Hassanipour M, Police S, O'Sullivan C, Collins L, Chen Y, Minami E, Gill EA, Ueno S, Yuan C, Gold J, Murry CE (2007): Cardiomyocytes derived from human embryonic stem cells in pro-survival factors enhance function of infarcted rat hearts. Nat Biotechnol 25(9), 1015-1024.

Lamba DA, Gust J, Reh TA (2009): Transplantation of human embryonic stem cellderived photoreceptors restores some visual function in Crx-deficient mice. Cell Stem Cell $4(1), 73-79$.

Laugwitz KL, Moretti A, Lam J, Gruber P, Chen Y, Woodard S, Lin LZ, Cai CL, Lu MM, Reth M, Platoshyn O, Yuan JX, Evans S, Chien KR (2005): Postnatal isl1+ cardioblasts enter fully differentiated cardiomyocyte lineages. Nature $433(7026), 647-$ 653.

Leblond CP (1964): Classification of cell populations on the basis of their proliferative behavior. Natl Cancer Inst Monogr 14, 119-150.

Leri A, Kajstura J, Anversa P (2005): Cardiac stem cells and mechanisms of myocardial regeneration. Physiol Rev 85(4), 1373-1416. 
Lo LC, Johnson JE, Wuenschell CW, Saito T, Anderson DJ (1991): Mammalian achaete-scute homolog 1 is transiently expressed by spatially restricted subsets of early neuroepithelial and neural crest cells. Genes Dev $\underline{5}(9), 1524-1537$.

Loh YH, Wu Q, Chew JL, Vega VB, Zhang W, Chen X, Bourque G, George J, Leong B, Liu J, Wong KY, Sung KW, Lee CW, Zhao XD, Chiu KP, Lipovich L, Kuznetsov VA, Robson P, Stanton LW, Wei CL, Ruan Y, Lim B, Ng HH (2006): The Oct4 and Nanog transcription network regulates pluripotency in mouse embryonic stem cells. Nat Genet 38(4), 431-440.

Lyons GE, Schiaffino S, Sassoon D, Barton P, Buckingham M (1990): Developmental regulation of myosin gene expression in mouse cardiac muscle. J Cell Biol 111(6 Pt 1), 2427-2436.

Maherali N, Sridharan R, Xie W, Utikal J, Eminli S, Arnold K, Stadtfeld M, Yachechko R, Tchieu J, Jaenisch R, Plath K, Hochedlinger K (2007): Directly reprogrammed fibroblasts show global epigenetic remodeling and widespread tissue contribution. Cell Stem Cell 1, 55-70.

Martin GR (1981): Isolation of a pluripotent cell line from early mouse embryos cultured in medium conditioned by teratocarcinoma stem cells. Proc Natl Acad Sci U S A $\underline{78(12), ~ 7634-7638 . ~}$

Martin CM, Meeson AP, Robertson SM, Hawke TJ, Richardson JA, Bates S, Goetsch SC, Gallardo TD, Garry DJ (2004): Persistent expression of the ATP-binding cassette transporter, Abcg2, identifies cardiac SP cells in the developing and adult heart. Dev Biol 265(1), 262-275.

Masui S, Nakatake Y, Toyooka Y, Shimosato D, Yagi R, Takahashi K, Okochi H, Okuda A, Matoba R, Sharov AA, Ko MS, Niwa H (2007): Pluripotency governed by Sox2 via regulation of Oct3/4 expression in mouse embryonic stem cells. Nat Cell Biol $9(6), 625-635$.

Mauritz C, Schwanke K, Reppel M, Neef S, Katsirntaki K, Maier LS, Nguemo F, Menke S, Haustein M, Hescheler J, Hasenfuss G, Martin U (2008): Generation of functional murine cardiac myocytes from induced pluripotent stem cells. Circulation 118(5), 507-517.

McMurray J, Cohen-Solal A, Dietz R, Eichhorn E, Erhardt L, Hobbs R, Maggioni A, Pina I, Soler-Soler J, Swedberg K; Clinical Research Initiative in Heart failure (2001): Practical recommendations for the use of ACE inhibitors, beta-blockers and spironolactone in heart failure: putting guidelines into practice. Eur J Heart Fail $\underline{3}(4)$, 495-502.

McMurray JJ, Pfeffer MA (2005): Heart failure. Lancet 365(9474), 1877-1889.

Melo LG, Pachori AS, Kong D, Gnecchi M, Wang K, Pratt RE, Dzau VJ (2004): Molecular and cell-based therapies for protection, rescue, and repair of ischemic myocardium: reasons for cautious optimism. Circulation 109(20), 2386-2393. 
Menasché P (2008): Skeletal myoblasts and cardiac repair. J Mol Cell Cardiol 45(4),545-553.

Minina IM, Zhdanova NS, Shilov AG, Tolkunova EN, Liskovykh MA, Tomilin AN (2010): Chromosomal instability of in vitro cultured mouse embryonic stem cells and induced pluripotent stem cells. Tsitologiia 52(5), 420-425.

Mitsui K, Tokuzawa Y, Itoh H, Segawa K, Murakami M, Takahashi K, Maruyama M, Maeda M, Yamanaka S (2003): The homeoprotein Nanog is required for maintenance of pluripotency in mouse epiblast and ES cells. Cell 113, 631-642.

Moretti A, Caron L, Nakano A, Lam JT, Bernshausen A, Chen Y, Qyang Y, Bu L, Sasaki M, Martin-Puig S, Sun Y, Evans SM, Laugwitz KL, Chien KR (2006): Multipotent embryonic isl1+ progenitor cells lead to cardiac, smooth muscle, and endothelial cell diversification. Cell 127(6), 1151-1165.

Mouquet F, Pfister O, Jain M, Oikonomopoulos A, Ngoy S, Summer R, Fine A, Liao $R$ (2005): Restoration of cardiac progenitor cells after myocardial infarction by selfproliferation and selective homing of bone marrow-derived stem cells. Circ Res 97(11), 1090-1092.

Murry CE, Soonpaa MH, Reinecke H, Nakajima H, Nakajima HO, Rubart M, Pasumarthi KB, Virag JI, Bartelmez SH, Poppa V, Bradford G, Dowell JD, Williams DA, Field LJ (2004): Haematopoietic stem cells do not transdifferentiate into cardiac myocytes in myocardial infarcts. Nature 428(6983), 664-668.

Nagy A, Gócza E, Diaz EM, Prideaux VR, Iványi E, Markkula M, Rossant J (1990): Embryonic stem cells alone are able to support fetal development in the mouse. Development 110, 815-821.

Nagy A, Rossant J, Nagy R, Abramow-Newerly W, Roder JC (1993): Derivation of completely cell culture-derived mice from early-passage embryonic stem cells. Proc Natl Acad Sci U S A 90, 8424-8428.

Nakagawa M, Koyanagil M, Tanabe K, Takahashi K, Ichisaka T, Aoi T, Okita K, Mochiduki Y, Takizawa N, Yamanaka S (2008): Generation of induced pluripotent stem cells without Myc from mouse and human fibroblasts. Nature Biotechnology 26 , 101-106.

National Institutes of Health, U.S.A.

(http://www.ncbi.nlm.nih.gov/About/primer/genetics_cell.html).

National Institutes of Health, Department of Health and Human Services, U.S.A. (2001): Stem Cells: Scientific Progress and Future Research Directions.

Nelson TJ, Martinez-Fernandez A, Yamada S, Perez-Terzic C, Ikeda Y, Terzic A (2009): Repair of acute myocardial infarction by human stemness factor induced pluripotent stem cells. Circulation 120, 408-416. 
Nichols J, Zevnik B, Anastassiadis K, Niwa H, Klewe-Nebenius D, Chambers I, Schöler H, Smith A (1998): Formation of Pluripotent Stem Cells in the Mammalian Embryo Depends on the POU Transcription Factor Oct4. Cell 95, 379-391.

Nikitin NP, de Silva R, Cleland JG (2004): The utility of a comprehensive cardiac magnetic resonance examination for the evaluation of patients with heart failure. Heart 90(10), 1166.

Niwa H, Miyanzaki J, Smith AG (2000): Quantitative expression of Oct-3/4 defines differentiation, dedifferentiation or self-renewal of ES cells. Nature genetics 24, 372376.

Novak A, Barad L, Zeevi-Levin N, Shick R, Shtrichman R, Lorber A, Itskovitz-Eldor J, Binah O (2012): Cardiomyocytes generated from CPVTD307H patients are arrhythmogenic in response to $\beta$-adrenergic stimulation. $\mathrm{J}$ of Cell and Moll Med $\underline{16}$, 468-482.

Nussbaum J, Minami E, Laflamme MA, Virag JA, Ware CB, Masino A, Muskheli V, Pabon L, Reinecke H, Murry CE (2007): Transplantation of undifferentiated murine embryonic stem cells in the heart: teratoma formation and immune response. FASEB J 21(7), 1345-1357.

Nygren JM, Jovinge S, Breitbach M, Säwén P, Röll W, Hescheler J, Taneera J, Fleischmann BK, Jacobsen SE (2004): Bone marrow-derived hematopoetic cells generate cardiomyocytes at low frequency through cell fusion, but not transdifferentiation. Nat Med 10, 494-501.

Ogata K, Platt JL (2004): Cardiac xenotransplantation: future and limitations. Cardiology 101(1-3), 144-155.

Oh H, Bradfute SB, Gallardo TD, Nakamura T, Gaussin V, Mishina Y, Pocius J, Michael LH, Behringer RR, Garry DJ, Entman ML, Schneider MD (2003): Cardiac progenitor cells from adult myocardium: homing, differentiation, and fusion after infarction. Proc Natl Acad Sci U S A 100(21), 12313-12318.

Okita K, Ichisaka T, and Yamanaka S (2007): Generation of germline-competent induced pluripotent stem cells. Nature $\underline{448}, 313-317$.

Okita K, Nakagawa M, Hyenjong H, Ichisaka T, Yamanaka S (2008): Generation of mouse induced pluripotent stem cells without viral vectors. Science 322(5903), 949953.

Packer M (1993): The development of positive inotropic agents for chronic heart failure: how have we gone astray? J Am Coll Cardiol 22, 119-126.

Packer M (2001): Current role of beta-adrenergic blockers in the management of chronic heart failure. Am J Med 110, 81-94. 
Packer M, Fowler MB, Roecker EB, Coats AJ, Katus HA, Krum H, Mohacsi P, Rouleau JL, Tendera M, Staiger C, Holcslaw TL, Amann-Zalan I, DeMets DL; Carvedilol Prospective Randomized Cumulative Survival (COPERNICUS) Study Group (2002): Effect of carvedilol on the morbidity of patients with severe chronic heart failure: results of the carvedilol prospective randomized cumulative survival (COPERNICUS) study. Circulation 106(17), 2194-2199.

Park IH, Arora N, Huo H, Maherali N, Ahfeldt T, Shimamura A, Lensch MW, Cowan C, Hochedlinger K, Daley GQ (2008): Disease-specific induced pluripotent stem cells. Cell 134, 877-886.

Pitt B, Zannad F, Remme WJ, Cody R, Castaigne A, Perez A, Palensky J, Wittes J (1999): The effect of spironolactone on morbidity and mortality in patients with severe heart failure. Randomized Aldactone Evaluation Study Investigators. N Engl J Med 341(10), 709-717.

Quaini F, Urbanek K, Beltrami AP, Finato N, Beltrami CA, Nadal-Ginard B, Kajstura J, Leri A, Anversa P (2002): Chimerism of the transplanted heart. N Engl J Med 346(1), 5-15.

Reinecke H, Zhang M, Bartosek T, Murry CE (1999): Survival, Integration, and Differentiation of Cardiomyocyte Grafts. A Study in Normal and Injured Rat Hearts. Circulation 100, 193-202.

Richards M, Tan SP, Tan JH, Chan WK, Bongso A (2004): The transcriptome profile of human embryonic stem cells as defined by SAGE. Stem Cells 22(1), 51-64.

Rodda DJ, Chew JL, Lim LH, Loh YH, Wang B, Ng HH, Robson P (2005): Transcriptional regulation of nanog by OCT4 and SOX2. J Biol Chem 280, 2473124737.

Rose EA, Gelijns AC, Moskowitz AJ, Heitjan DF, Stevenson LW, Dembitsky W, Long JW, Ascheim DD, Tierney AR, Levitan RG, Watson JT, Meier P, Ronan NS, Shapiro PA, Lazar RM, Miller LW, Gupta L, Frazier OH, Desvigne-Nickens P, Oz MC, Poirier VL; Randomized Evaluation of Mechanical Assistance for the Treatment of Congestive Heart Failure (REMATCH) Study Group (2001): Long-term use of a left ventricular assist device for end-stage heart failure. N Engl J Med 345(20), 14351443.

Rubart M, Field LJ (2008): Stem cell differentiation: cardiac repair. Cells Tissues Organs 188(1-2), 202-211.

Rubart M, Pasumarthi KB, Nakajima H, Soonpaa MH, Nakajima HO, Field LJ (2003): Physiological coupling of donor and host cardiomyocytes after cellular transplantation. Circ Res 92(11), 1217-1224.

Sanchez A, Jones WK, Gulick J, Doetschman T, Robbins J (1991): Myosin heavy chain gene expression in mouse embryoid bodies. An in vitro developmental study. J Biol Chem 266(33), 22419-22426. 
Schenke-Layland K, Rhodes KE, Angelis E, Butylkova Y, Heydarkhan-Hagvall S, Gekas C, Zhang R, Goldhaber JI, Mikkola HK, Plath K, MacLellan WR (2008): Reprogrammed mouse fibroblasts differentiate into cells of the cardiovascular and hematopoietic lineages. Stem Cells 26(6), 1537-1546.

Schöler HR, Ruppert S, Suzuki N, Chowdhury K, Gruss P (1990): New type of POU domain in germ line-specific protein Oct-4. Nature 344(6265), 435-439.

Schröck E, Veldman T, Padilla-Nash H, Ning Y, Spurbeck J, Jalal S, Shaffer LG, Papenhausen P, Kozma C, Phelan MC, Kjeldsen E, Schonberg SA, O'Brien P, Biesecker L, du Manoir S, Ried T (1997): Spectral karyotyping refines cytogenetic diagnostics of constitutional chromosomal abnormalities. Hum Genet 101, 255-262.

Segers VF, Lee RT (2008): Stem-cell therapy for cardiac disease. Nature 451(7181), 937-942.

Shimizu T, Sekine H, Isoi Y, Yamato M, Kikuchi A, Okano T (2006): Long-term survival and growth of pulsatile myocardial tissue grafts engineered by the layering of cardiomyocyte sheets. Tissue Eng 12(3), 499-507.

Simonsson S, Gurdon J (2004): DNA demethylation is necessary for the epigenetic reprogramming of somatic cell nuclei. Nat Cell Biol $\underline{6}(10), 984-990$.

Smith AG (2001): Embryo-derived stem cells: Of mice and men. Annu Rev Cell Dev Biol 17, 435-462.

Solter D, Knowles BB (1978): Monoclonal antibody defining a stage-specific mouse embryonic antigen (SSEA-1). Proc Natl Acad Sci U S A 75(11), 5565-5569.

Somers A, Jean JC, Sommer CA, Omari A, Ford CC, Mills JA, Ying L, Sommer AG, Jean JM, Smith BW, Lafyatis R, Demierre MF, Weiss DJ, French DL, Gadue P, Murphy GJ, Mostoslavsky G, Kotton DN (2010): Generation of transgene-free lung disease-specific human induced pluripotent stem cells using a single excisable lentiviral stem cell cassette. Stem Cells $28,1728-1740$.

Sommer CA, Stadtfeld M, Murphy GJ, Hochedlinger K, Kotton DN, Mostoslavsky G (2009): Induced pluripotent stem cell generation using a single lentiviral stem cell cassette. Stem Cells 27, 543-549.

Sommer CA, Sommer AG, Longmire TA, Christodoulou C, Thomas DD, Gostissa M, Alt FW, Murphy GJ, Kotton DN, Mostoslavsky G (2010): Excision of reprogramming transgenes improves the differentiation potential of iPS cells generated with a single excisable vector. Stem Cells 28, 64-74.

Speicher M, Ballard SG, Ward DC (1996): Karyotyping human chromosomes by combinatorial multi-fluor FISH. Nat Genet 12, 368-375.

Sridharan R, Tchieu J, Mason MJ, Yachechko R, Kuoy E, Horvath S, Zhou Q, Plath $\mathrm{K}$ (2009): Role of the murine reprogramming factors in the induction of pluripotency. Cell 136(2), 364-377. 
Stadtfeld M, Nagaya M, Utikal J, Weir G, Hochedlinger K (2008): Induced pluripotent stem cells generated without viral integration. Science 322, 945-949.

Streckfuss-Bomecke K, Wolf F, Azizian A, Stauske M, Tiburcy M, Wagner S, Hubscher D, Dressel R, Chen S, Jende J, Wulf G, Lorenz V, Schon M, Maier LS, Zimmermann WH, Hasenfuss G, Guan K (2013): Comparative study of humaninduced pluripotent stem cells derived from bone marrow cells, hair keratinocytes, and skin fibroblasts. Eur Heart J 12. doi: 10.1093/eurheartj/ehs203.

[SOLVD (No authors listed)] (1991): Effect of enalapril on survival in patients with reduced left ventricular ejection fractions and congestive heart failure. The SOLVD Investigators. N Engl J Med 325(5), 293-302

Stuckey DJ, Carr CA, Martin-Rendon E, Tyler DJ, Willmott C, Cassidy PJ, Hale SJ, Schneider JE, Tatton L, Harding SE, Radda GK, Watt S, Clarke K (2006): Iron particles for noninvasive monitoring of bone marrow stromal cell engraftment into, and isolation of viable engrafted donor cells from, the heart. Stem Cells 24(8), 19681975.

Sun N, Yazawa M, Liu J, Han L, Sanchez-Freie V, Abilez OJ, Navarrete EG, Hu S, Wang L, Lee A, Pavlovic A, Lin S, Chen R, Hajjar RJ, Snyder MP, Dolmetsch RE, Butte MJ, Ashley EA, Longaker MT, Robbins RC, Wu JC (2012): Patient-specific induced pluripotent stem cells as a model for familial dilated cardiomyopathy. Sci Transl Med 4(130), 130ra47

Tada M, Tada T, Lefebvre L, Barton SC, Surani MA (1997): Embryonic germ cells induce epigenetic reprogramming of somatic nucleus in hybrid cells. EMBO J 16(21), 6510-6520.

Tada M, Takahama Y, Abe K, Nakatsuji N, Tada T (2001): Nuclear reprogramming of somatic cells by in vitro hybridization with ES cells. Current Biology 11, 1553-1558.

Takahashi K, Yamanaka S (2006): Induction of pluripotent stem cells from mouse embryonic and adult fibroblast cultures by defined factors. Cell 126, 663-676.

Takahashi K, Tanabe K, Ohnuki M, Narita M, Ichisaka T, Tomoda K, Yamanaka S (2007): Induction of pluripotent stem cells from adult human fibroblasts by defined factors. Cell 131, 861-872.

Tao Y, Rubart M, Soonpa MH, Didie M, Christalla P, Zimmermann WH, Field LJ (2015): Cardiac Engraftment of Genetically-Selected Parthenogenetic Stem CellDerivied Cardiomyocytes. PLoS One 10(6), e0131511.

Thomson JA, Kalishman J, Golos TG, Durning M, Harris CP, Becker RA, Hearn JP (1995): Isolation of a primate embryonic stem cell line. Proc Natl Acad Sci U S A 92, 7844-7848.

Thomson JA, Kalishman J, Golos TG, Durning M, Harris CP, Hearn JP (1996): Pluripotent cell lines derived from common marmoset (Callithrix jacchus) blastocysts. Biol Reprod 55, 254-259. 
Thomson JA, Itskovitz-Eldor J, Shapiro SS, Waknitz MA, Swiergiel JJ, Marshall VS, Jones JM (1998): Embryonic stem cell lines derived from human blastocysts. Science 282, 1145-1147.

Trulock EP, Edwards LB, Taylor DO, Boucek MM, Keck BM, Hertz MI (2004): The Registry of the International Society for Heart and Lung Transplantation: twenty-first official adult lung and heart-lung transplant report--2004. J Heart Lung Transplant 23(7), 804-815.

Wang J, Rao S, Chu J, Shen X, Levasseur DN, Theunissen TW, Orkin SH (2006): A protein interaction network for pluripotency of embryonic stem cells. Nature 444(7117), 364-368.

Warren L, Manos PD, Ahfeldt T, Loh YH, Li H, Lau F, Ebina W, Mandal PK, Smith ZD, Meissner A, Daley GQ, Brack AS, Collins JJ, Cowan C, Schlaeger TM, Rossi DJ (2010): Highly efficient reprogramming to pluripotency and directed differentiation of human cells with synthetic modified mRNA. Cell Stem Cell $\underline{\text { 7, 618-630. }}$

Wei CL, Miura T, Robson P, Lim SK, Xu XQ, Lee MY, Gupta S, Stanton L, Luo Y, Schmitt J, Thies S, Wang W, Khrebtukova I, Zhou D, Liu ET, Ruan YJ, Rao M, Lim B (2005): Transcriptome profiling of human and murine ESCs identifies divergent paths required to maintain the stem cell state. Stem Cells 23(2), 166-185.

Wei JY (1992): Age and the cardiovascular system. N Engl J Med 327(24), 17351739 .

Wernig M, Meissner A, Foreman R, Brambrink T, Ku M, Hochedlinger K, Bernstein $B E$, Jaenisch R (2007): In vitro reprogramming of fibroblasts into a pluripotent EScell-like-state. Nature $448,318-324$.

Wilmut I, Schnieke AE, McWhir J, Kind AJ, Campbell KH (1997): Viable offspring derived from fetal and adult mammalian cells. Nature 385(6619), 810-813.

Wobus AM, Boheler KR (2005): Embryonic stem cells: prospects for developmental biology and cell therapy. Physiol Rev 85(2), 635-678.

Wobus AM, Holzhausen H, Jäkel P, Schöneich J (1984): Characterization of a pluripotent stem cell line derived from a mouse embryo. Exp Cell Res 152(1), 212219.

Xu C, Police S, Rao N, Carpenter MK (2002): Characterization and enrichment of cardiomyocytes derived from human embryonic stem cells. Circ Res 91(6), 501-508.

Xu XQ, Zweigerdt R, Soo SY, Ngoh ZX, Tham SC, Wang ST, Graichen R, Davidson B, Colman A, Sun W (2008): Highly enriched cardiomyocytes from human embryonic stem cells. Cytotherapy 10(4), 376-389.

Yang DH, Moss EG (2003): Temporally regulated expression of Lin-28 in diverse tissues of the developing mouse. Gene Expr Patterns $\underline{3}(6), 719-726$. 
Yang L, Soonpaa MH, Adler ED, Roepke TK, Kattman SJ, Kennedy M, Henckaerts E, Bonham K, Abbott GW, Linden RM, Field LJ, Keller GM. (2008): Human cardiovascular progenitor cells develop from a KDR+ embryonic-stem-cell-derived population. Nature $453,524-528$.

Yoshida Y, Yamanaka S (2011): iPS cells: a source of cardiac regeneration. J Mol Cell Cardiol 50(2), 327-332.

Yu J, Vodyanik MA, Smuga-Otto K, Antosiewicz-Bourget J, Frane JL, Tian S, Nie J, Jonsdottir GA, Ruotti V, Stewart R, Slukvin II, Thomson JA (2007): Induced pluripotent stem cell lines derived from human somatic cells. Science 318, 19171920.

Yu J, Hu K, Smuga-Otto K, Tian S, Stewart R, Slukvin II, Thomson JA (2009): Human induced pluripotent stem cells free of vector and transgene sequences. Science 324, 797-801.

Zaruba MM, Soonpaa M, Reuter S, Field LJ (2010): Cardiomyogenic potential of Ckit(+)-expressing cells derived from neonatal and adult mouse hearts. Ciculation 121(18), 1992-2000. 


\section{Danksagung}

Ich möchte mich ganz herzlich bei allen bedanken, die mich bei dieser Doktorarbeit in jeglicher Weise unterstützt haben.

\section{Ein besonderer Dank gilt}

Prof. Dr. med. G. Hasenfuß für die Möglichkeit, meine Doktorarbeit in der Klinik für Kardiologie und Pneumologie zu erstellen,

Prof. Dr. rer. nat. K. Guan-Schmidt für die Bereitstellung ihrer Expertise, ihres Labors und für eine hervorragenden Betreuung,

Dr. med. A. Becker für die Bereitstellung des Themas meiner Doktorarbeit und seine intensive Betreuung,

dem gesamten Team des Stammzelllabors unter der Leitung von Prof. Dr. rer. nat. K. Guan-Schmidt, vor allem Dr. rer. nat. K. Streckfuss-Boemecke und Dr. rer. nat. M. Stauske sowie Dr. rer. nat. D. Hübscher für eine großartige Unterstützung. 


\section{Lebenslauf}

Mein Name ist Max-Philipp Lentzen, ich bin ledig und wurde am 17.02.1988 in Berlin als ältester von zwei Söhnen von Dr. Monika Nick-Lentzen und Prof. Dr. Hans Lentzen geboren. Meine Mutter war als Ärztin tätig und mein Vater ist selbständiger Pharmakologe. Ich besitze die deutsche Staatsbürgerschaft und wohne in der Burgstraße 32 in 37073 Göttingen. Telefonnummer: 0178/5357262 oder per Email: max-philipp.lentzen@hotmail.com

Mein schulischer Werdegang begann 1994 an der Freien Waldorfschule Bergisch Gladbach, diesen schloss ich mit dem Erwerb der Allgemeinen Hochschulreife (Note: 2,2) in den Fächern Mathematik, Deutsch, Englisch, Erdkunde, Geschichte, Russisch, Biologie und Sport ab.

Von September 2008 bis September 2009 studierte ich zunächst ein Jahr Medizin an der Semmelweis Universität in Budapest, bis ich im Oktober 2009 einen Medizinstudienplatz an der Georg-August Universität Göttingen bekam. Hier absolvierte ich am 21.03.2011 erfolgreich den Ersten Abschnitt der Ärztlichen Prüfung mit der Note: Gut. Im November 2011 begann ich im Stammzelllabor der Abteilung für Kardiologie und Pneumologie unter der Leitung von PD Dr. K. GuanSchmidt meine Doktorarbeit mit dem Titel „In-vitro-Charakterisierung und kardiale Differenzierung von induziert pluripotenten Stammzellen der Maus“. Um mich intensiver der Arbeit im Labor widmen zu können, nahm ich im Sommersemester 2012 ein Freisemester. Freundlicherweise wurde ich bei meiner Doktorarbeit durch ein Stipendium zur Förderung wissenschaftlicher Tätigkeiten „gö4med“ im Rahmen der Exzellenzinitiative der Georg-August Universität Göttingen unterstützt. Mein besonderes Interesse erweckten während des Studiums Famulaturen in der Klinik für Mund-, Kiefer- und Plastische Gesichtschirurgie, so dass ich ebenfalls das Wahltertial meines Praktischen Jahres in der MKG-Chirurgie der Uniklinik Köln absolvierte. Die weiteren Tertiale meines PJ verbrachte ich in der Chirurgie an der University of Stellenbosch in Südafrika und in der Inneren Medizin der Universitätsmedizin Göttingen.

Nach Abschluss meines Medizinstudiums und erfolgreicher Promotion möchte ich gerne dem Humanmedizinstudium ein Zahnmedizinstudium folgen lassen und bewerbe mich derzeit auf eine halbe Stelle zum Facharzt für Mund-, Kiefer- und Plastische Gesichtschirurgie begleitend zum Zahnmedizinstudium. 